Small import-dependent countries, especially in Africa, were deeply affected by the food and economic crises. Some large countries were able to insulate themselves from the crisis through restrictive trade policies and functioning safety nets, but trade insulation increased prices and volatility on international markets.

High and volatile food prices are likely to continue. Demand from consumers in rapidly growing economies will increase, population continues to grow, and any further growth in biofuels will place additional demands on the food system. On the supply side, there are challenges due to increasingly scarce natural resources in some regions, as well as declining rates of yield growth for some commodities. Food price volatility may increase due to stronger linkages between agricultural and energy markets, as well as an increased frequency of weather shocks.

Price volatility makes both smallholder farmers and poor consumers increasingly vulnerable to poverty. Because food represents a large share of farmer income and the budget of poor consumers, large price changes have large effects on real incomes. Thus, even short episodes of high prices for consumers or low prices for farmers can cause productive assets - land and livestock, for example - to be sold at low prices, leading to potential poverty traps. In addition, smallholder farmers are less likely to invest in measures to raise productivity when price changes are unpredictable.

\section{Large short-term price changes can have long-term} impacts on development. Changes in income due to price swings can reduce children's consumption of key nutrients during the first 1000 days of life from conception, leading to a permanent reduction of their future earning capacity, increasing the likelihood of future poverty and thus slowing the economic development process.

\section{High food prices worsen food insecurity in the short} term. The benefits go primarily to farmers with access to sufficient land and other resources, while the poorest of the poor buy more food than they produce. In addition to harming the urban poor, high food prices also hurt many of the rural poor, who are typically net food buyers. The diversity of impacts within countries also points to a need for improved data and policy analysis.
High food prices present incentives for increased long-term investment in the agriculture sector, which can contribute to improved food security in the longer term. Domestic food prices increased substantially in most countries during the 2006-08 world food crisis at both retail and farmgate levels. Despite higher fertilizer prices, this led to a strong supply response in many countries. It is essential to build upon this short-term supply response with increased investment in agriculture, including initiatives that target smallholder farmers and help them to access markets, such as Purchase for Progress (P4P).

Safety nets are crucial for alleviating food insecurity in the short term, as well as for providing a foundation for long-term development. In order to be effective at reducing the negative consequences of price volatility, targeted safety-net mechanisms must be designed in advance and in consultation with the most vulnerable people.

A food-security strategy that relies on a combination of increased productivity in agriculture, greater policy predictability and general openness to trade will be more effective than other strategies. Restrictive trade policies can protect domestic prices from world market volatility, but these policies can also result in increased domestic price volatility as a result of domestic supply shocks, especially if government policies are unpredictable and erratic. Government policies that are more predictable and that promote participation by the private sector in trade will generally decrease price volatility.

Investment in agriculture remains critical to sustainable long-term food security. Such investment will improve the competitiveness of domestic production, increase farmers' profits and make food more affordable for the poor. For example, cost-effective irrigation and improved practices and seeds developed through agricultural research can reduce the production risks facing farmers, especially smallholders, and reduce price volatility. Private investment will form the bulk of the needed investment, but public investment has a catalytic role to play in supplying public goods that the private sector will not provide. These investments should consider the rights of existing users of land and related natural resources, benefit local communities, promote food security and not cause undue harm to the environment. 


\section{The State of \\ Food Insecurity in the World}

How does international price volatility affect domestic economies and food security? 
The designations employed and the presentation of material in this information product do not imply the expression of any opinion whatsoever on the part of the Food and Agriculture Organization of the United Nations (FAO), the International Fund for Agricultural Development (IFAD) or of the World Food Programme (WFP) concerning the legal or development status of any country, territory, city or area or of its authorities, or concerning the delimitation of its frontiers or boundaries. The mention of specific companies or products of manufacturers, whether or not these have been patented, does not imply that these have been endorsed or recommended by FAO, IFAD or WFP in preference to others of a similar nature that are not mentioned.

The designations employed and the presentation of material in the maps do not imply the expression of any opinion whatsoever on the part of FAO, IFAD or WFP concerning the legal or constitutional status of any country, territory or sea area, or concerning the delimitation of frontiers.

ISBN 978-92-5-106927-1

All rights reserved. FAO encourages the reproduction and dissemination of material in this information product. Non-commercial uses will be authorized free of charge, upon request. Reproduction for resale or other commercial purposes, including educational purposes, may incur fees. Applications for permission to reproduce or disseminate FAO copyright materials, and all queries concerning rights and licences, should be addressed by e-mail to copyright@fao.org or to the Chief, Publishing Policy and Support Branch, Office of Knowledge Exchange, Research and Extension, FAO, Viale delle Terme di Caracalla, 00153 Rome, Italy. 


\section{Foreword}

8 Undernourishment around the world: impact of the 2006-08 price shock

8 The crises hit the poor and the weak

10 Revising FAO's methodology for measuring hunger

11 Recent trends in world food commodity prices: costs and benefits

11 Past and future trends in world food prices

13 Costs and benefits of high and low food prices

18 Costs and benefits of volatile and unpredictable prices

21 Lessons from the world food crisis of 2006-08

32 Policy options to address price volatility and high prices

34 Preventing domestic price volatility in the short term trade policies and buffer stocks

37 Coping with likely future price volatility: risk management for smallholder farmers and governments

39 Coping with price volatility after the fact: targeted safety nets and emergency food reserves

42 Preventing price volatility in the long term: increasing the productivity, sustainability and resilience of agriculture

\section{Technical annex}

$44 \quad$ Annex table

Prevalence of undernourishment and progress towards the World Food Summit (WFS) and the Millennium Development Goal (MDG) targets in developing countries

$48 \quad$ Notes 


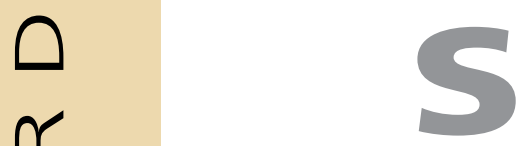

mall import-dependent countries, especially in Africa, were deeply affected by the food and economic crises. Indeed, many countries are still in crisis in different parts of the world, particularly the Horn of Africa. These crises are challenging our efforts to achieve the Millennium Development Goal (MDG) of reducing the proportion of people who suffer from hunger by half by 2015. Even if the MDG were to be achieved by 2015 some 600 million people in developing countries would still be undernourished. Having 600 million human beings suffering from hunger on a daily basis is never acceptable. The entire international community must act today, and act forcefully and responsibly to banish food insecurity from the planet.

This edition of The State of Food Insecurity in the World focuses on food price volatility. Our organizations continue to monitor food prices, and have alerted the world through a number of analytical reports on food price trends and ongoing volatility in recent years, as these continue to be a matter of concern for governments and people around the world. Indeed, high and volatile food prices are widely expected to continue in the future. Thus, we are pleased that in 2011 the Group of 20 Finance Ministers and Central Bank Governors (G20) have been actively pursuing policy options for reducing food price volatility.

By using previously unavailable data sources and studies, this report digs underneath the globalscale analyses to find out what happened on domestic markets and to draw lessons from the world food crisis of 2006-08. In particular, the report emphasizes that the impact of world price changes on household food security and nutrition is highly context-specific. The impact depends on the commodity, the national policies that affect price transmission from world markets to domestic markets, the demographic and production characteristics of different households and a range of other factors. This diversity of impacts, both within and between countries, points to a need for improved data and analysis so that governments can implement better policies. Better and more predictable policies can not only reduce unwanted side-effects on other countries, but can simultaneously reduce food insecurity and domestic price volatility at home. This report also distinguishes clearly between the level of food prices and fluctuations in food prices (price volatility) because the costs and benefits of high food prices are very different from the costs of price volatility, especially when the fluctuations are not predictable.

We also continue to highlight the importance of the twin track approach - improving both short-term access to food and food production in the medium term - in achieving long-lasting improvements in food security. In the short term, it is critical to design cost-effective safety nets that deliver the right targeted assistance to the right people at the right time. These short-term interventions are important to poor families because even temporary interruptions in intake of energy, protein, vitamins and minerals during the first 1000 days of a child's life can lead to permanent reductions in cognitive capacities and, hence, earnings potential. In some cases, this will be consumers whose disposable income is severely affected by higher food prices. In other cases, it will be poor smallholder farmers who need help to cope with high input prices that, in the absence of well-functioning credit markets, may prevent these farmers from boosting their production and providing much-needed supplies on domestic and global markets, as well as increasing their income.

In the long term, investment in agriculture and improving resilience among farmers remain key to providing sustained access to food for all and reducing vulnerability to price volatility and natural disasters such as drought. Improved seeds and farm management techniques, as well as irrigation and fertilizer, that sustainably increase productivity and reduce production risk must be delivered to farmers, especially smallholders, by both the private and the public sector.

Governments must ensure that a transparent and predictable regulatory environment is in place, one that promotes private investment and increases farm productivity. We must reduce food waste in developed countries through education and policies, and reduce food losses in developing countries by boosting investment in the entire value chain, especially post-harvest processing. More sustainable management of our natural resources, forests and fisheries are critical for the food security of many of the poorest members of society.

We are optimistic that global food security will be achieved. We have made progress in the past and will make more progress in the future, but only if we are committed to favourable policies, market information transparency, sound analysis, good science and adequate funding for appropriate interventions. The entire international community must commit to raising the profile of 
the agriculture-food system not just for the next few years but until the time when everyone, at all times, has physical, social and economic access to sufficient, safe and nutritious food that meets their dietary needs and food preferences for an active and healthy life. And even then, agriculture and food security must continue to be a priority for both national governments and the global community to ensure sustainability of achievements. Increased investment in agriculture, safety nets targeted at the most vulnerable, and measures to reduce food price volatility need to be an integral part of this commitment.

This is the third edition of this report that has been produced collaboratively between FAO and the World Food Programme (WFP) in what has proved to be a fruitful venture. This year, for the first time, the International Fund for Agricultural Development (IFAD) has joined in this collaboration. With our three organizations working together we expect the report to continue to grow in the relevance of its analysis and robustness of its results. We also thank the United States Department of Agriculture for its continued willingness to share its expertise and contribute to this report.

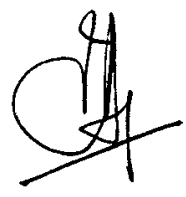

Jacques Diouf

FAO Director-General

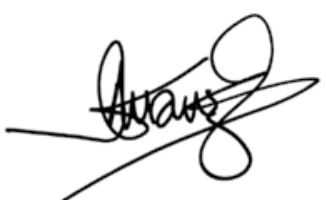

Kanayo F. Nwanze

IFAD President

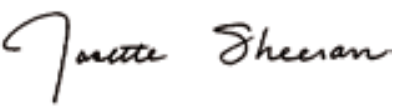

Josette Sheeran

WFP Executive Director 
The State of Food Insecurity in the World 2011 was prepared under the overall leadership of Hafez Ghanem, Assistant Director-General, and the guidance of the management team of the Economic and Social Development Department. The technical coordination of the publication was carried out by David Dawe (who was also the technical editor of the report), Kostas Stamoulis and Keith Wiebe of the Agricultural Development Economics Division (ESA). Michelle Kendrick provided coordination for all the editorial, graphics, layout and publishing services. Anna Doria Antonazzo provided excellent administrative support throughout, and the staff of the Statistics Division (ESS) generated the underlying data on undernourishment.

This is the third edition of this report that has been jointly prepared by FAO and the World Food Programme (WFP). In addition, the International Fund for Agricultural Development (IFAD) has also joined as a co-publisher this year. Lynn Brown (WFP) and Geoffrey Livingston (IFAD) coordinated the support from their respective institutions. Kevin Cleaver and Shantanu Mathur of IFAD also provided encouragement to this joint venture.

The chapter 'Undernourishment around the world' was prepared by the Statistics Division (ESS) of the Economic and Social Development Department with key technical contributions provided by Carlo Cafiero, Pietro Gennari, Josef Schmidhuber and Shahla Shapouri (the latter from the Economic Research Service of the United States Department of Agriculture [USDA]).

The remaining three chapters were prepared by the Economic and Social Development Department with technical contributions from Mulat Demeke (ESA); Adam Prakash and George Rapsomanikis, Trade and Markets Division (EST); and Ana Paula de la O Campos and Elisabeth Garner, Gender, Equity and Rural Employment Division (ESW). The box on forests and food security was prepared by Paul Vantomme of the Forestry Department. The box on WFP's experience during the food crisis was contributed by Lynn Brown of WFP. George Rapsomanikis (EST) contributed the box on outcomes of the G20 Agriculture Ministers' Meeting.

Carlo Cafiero and Cinzia Cerri produced the Technical annex under the guidance of Pietro Gennari, with support from Gladys Moreno-Garcia, Seevalingum Ramasawmy, Kari Rummukainen and Nathalie Troubat of ESS.

Valuable external comments, suggestions and inputs from Derek Headey (International Food Policy Research Institute [IFPRI]) and Peter Timmer (Harvard University) on an early draft of this report were extremely helpful, as were comments at various stages from Ann Tutwiler, Deputy Director General for Knowledge, FAO; Boubaker BenBelhassen in the Office of the Director-General (ODG); Erdgin Mane (ESA); Carlo Cafiero and Josef Schmidhuber (ESS); Merritt Cluff, David Hallam and Jamie Morrison (EST); Eve Crowley (ESW); Hubert George of the Natural Resources Management and Environment Department, Land and Water Division (NRL); Astrid Agostini, Sophie Descargues, Guy Evers, Claudio Gregorio, Mohamed Manssouri, Suzanne Raswant, Eugenia Serova, Garry Smith and Benoist Veillerette of the Technical Cooperation Department, Investment Division (TCI); Louis Bockel, Karel Callens, Arianna Carita, Richard China, Gunther Feiler, Stefano Gavotti, and David Phiri of the Technical Cooperation Department, Policy and Programme Development Support Division (TCS); and Ganesh Thapa of the Asia Division (IFAD). Ali Doroudian and Cristian Morales-Opazo provided invaluable research support.

Various data were kindly shared by Solomon Asfaw and Romina Cavatassi (ESA); Erika Felix and Irini Maltsoglou of the Natural Resources and Environment Department, Climate, Energy and Tenure Division (NRC); Mousa Kabore (Director) and Adama Koursangama, Direction de la Prospective, des Statistiques Agricoles et Alimentaires (DPSA), Direction Generale de la Promotion de I'Economie Rurale (DGPER), Ministère de l'agriculture, de I'hydraulique, et des ressources halieutiques, Burkina Faso; and Piedad Moya (International Rice Research Institute).

The readability of the report was greatly enhanced by Paul Neate, who provided English editorial support. The language editing, graphic and layout services were provided by Flora Dicarlo and Visiontime. Translations and printing services were provided by the Meeting Programming and Documentation Service of the Corporate Services, Human Resources and Finance Department. 



\section{Undernourishment around the world: impact of the 2006-08 price shock}

\section{The crises hit the poor and the weak}

\begin{abstract}
Key message
Small import-dependent countries, especially in Africa, were deeply affected by the food and economic crises. Some large countries were able to insulate their markets from the crisis through restrictive trade policies and protect their consumers through safety nets. However, trade insulation increased prices and volatility in international markets.
\end{abstract}

Tris: he estimated impact of the price shock of 2006-08 on the number of undernourished varied markedly across regions and individual countries. ${ }^{1}$ Different net trade positions (e.g. exporter, importer) and different policy responses to the price and income shocks held the key to the range of outcomes. The countries most exposed to price swings on international markets were typically poor and food importers: they had few reserves and inadequate budgetary means to procure food at high prices; they also lacked the option of restricting exports. They had to bear the brunt of the crisis, and domestic staple food prices rose substantially in these countries. Most of these countries were in Africa, and Figure 1 captures these divergent trends in undernourishment in Africa and Asia. Between 2007 and 2008, the number of undernourished was essentially constant in Asia (an increase of 0.1 percent), while it increased by 8 percent in Africa.

Trade policies were an important determinant of outcomes - many countries imposed export restrictions or reduced import barriers. In addition to trade policies, releasing public stocks and providing consumer subsidies were among the most common measures adopted as countries sought to contain the problem of rising food prices. ${ }^{2}$

Broadly speaking, three main groups of countries emerged, distinguished by their ability to limit the price shock or mitigate its effects. These are shown in Figure 2, which depicts the experiences of countries along two dimensions: the percentage change in real domestic food prices from 2007 to

FIGURE 1

Undernourishment in the world: two very different trends after the crises

Africa

\section{Millions}

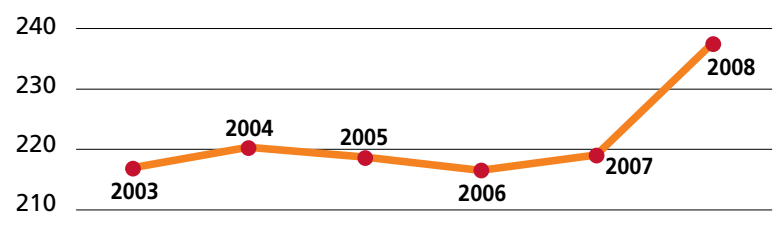

200

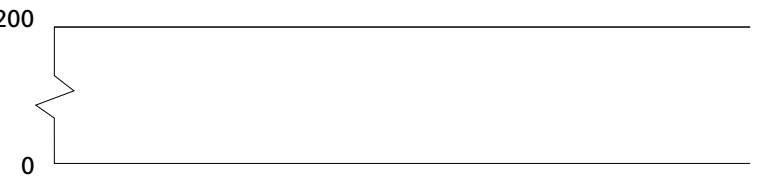

Asia

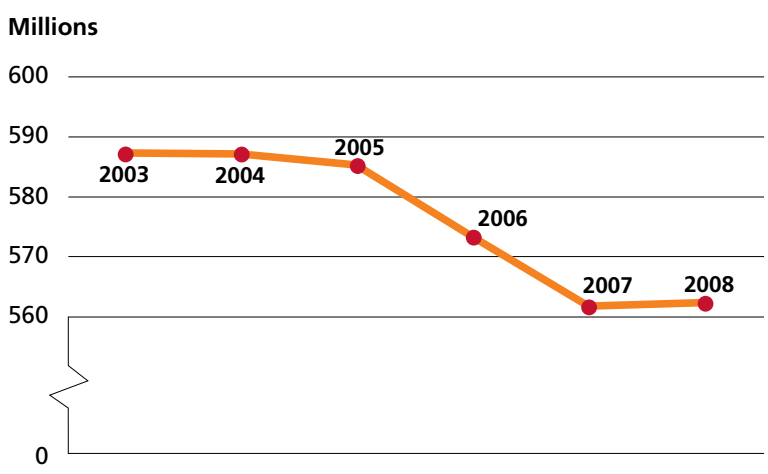


2008 and the percentage change in the number of undernourished from 2006-07 to 2009. The first group had relatively small domestic price increases from 2007 to 2008, coupled with progress in reducing undernourishment. These countries are located towards the lower left of the figure. The second group, located towards the upper left of the figure, had relatively large domestic price increases, but made progress in reducing undernourishment. Finally, the third group also had relatively large domestic price increases, but witnessed increases in undernourishment. These countries are located in the upper right of the figure.

\section{The first group of countries used a combination of trade} restrictions, safety nets and stock releases. This allowed them to shelter their food markets from the international turbulence, but the effectiveness of such policies is dependent upon having the necessary resources to implement them. Inclusive safety net programmes (such as those in Brazil) imply expenditures that many countries may not be able to afford, especially during a crisis. Export restrictions result in a loss of government revenue and reduce the potential for farmers to gain by increasing their production in response to higher prices. And food stocks are expensive to hold, meaning that poor countries may not have had the stocks available before the crisis to compensate for any domestic production shortfalls. This first group of countries, including China and India, cluster in the lower left hand part of Figure 2. Unfortunately, the export restrictions exacerbated price increases in international markets and compounded the impacts of food shortages in import-dependent countries.

The second group benefited from higher prices as the majority of the poor in these countries are net food sellers. Their incomes generally rose with higher prices even if some of the profits were partially reduced by higher prices for inputs such as fertilizer, seeds or fuel. These countries are often net food exporters with a relatively equal distribution of land (which means there are more farmers with a surplus to sell). This group of countries, including Thailand and Viet Nam, tend to be in the upper left hand part of Figure 2.

\section{FIGURE 2}

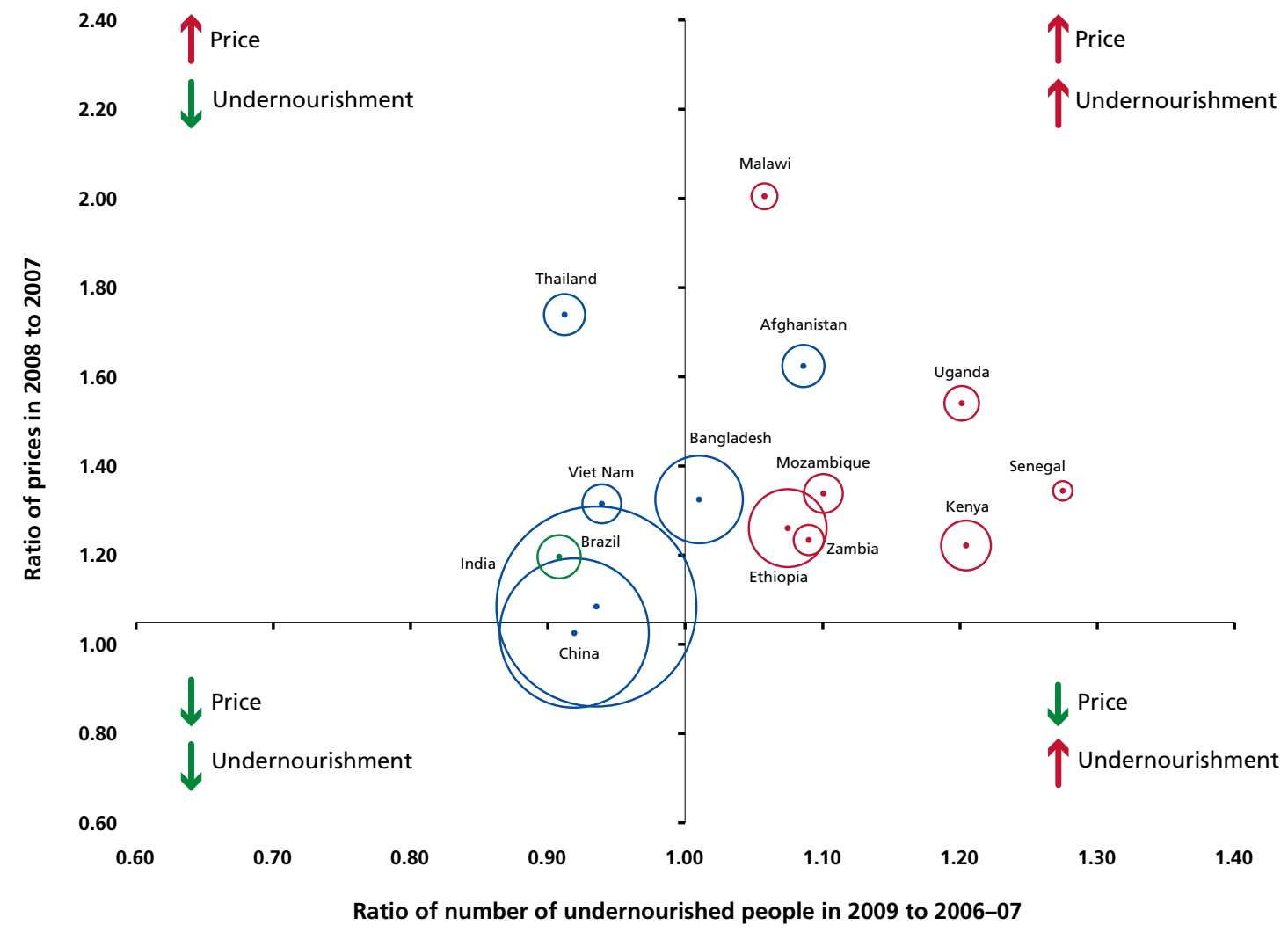

Notes: The size of the bubbles is proportional to the number of undernourished in 2008. African countries are shown in red, Asian countries in blue and Latin American countries in green. Prices used are inflation-adjusted retail prices of major staple foods in main markets, weighted by the population of each market and the share in energy intake of each staple food.
Source of raw data: FAO. 
The third group comprises countries that generally depend on food imports. They were exposed to higher international prices for food commodities, were typically without sufficient stocks, and did not have the budgetary resources to adequately protect the food security of the poor. These countries bore the brunt of the crisis (see countries towards the top right of Figure 2). Many of them imported far less on a commercial basis than was needed due to a shortage of foreign exchange, and were forced to appeal for external assistance and food aid. The Government of Burkina Faso, for example, implemented subsidized sales of grain but was forced to rely on WFP to assist 600000 beneficiaries (through school feeding and mother and child health centres) in 2008. The Ethiopian Government sold about 190000 tonnes of wheat from its grain reserve to about 800000 urban poor and imported 150000 tonnes of wheat in August/September 2008 to meet demand in urban areas, while WFP and nongovernmental organizations channelled about 200000 tonnes of food to the increasing number of people requiring food assistance.

\section{Revising FAO's methodology for measuring hunger}

During its meeting in 2010, the Committee on World Food Security (CFS) asked FAO to review its methodology for estimating undernourishment in order to provide more timely updates and incorporate all relevant information, including analysis of the large number of household surveys that have become available in recent years. Thus, this year is one of transition while the FAO methodology is being revised. Therefore, no updated estimates for the number of undernourished people in 2009 and 2010 are reported in this year's State of Food Insecurity in the World, nor has an estimate been made for 2011.

In order to improve its methodology, FAO will make several adjustments, including in the estimation of how changes in food access due to changes in income and food prices affect undernourishment. Work is also underway to improve the construction of food balance sheets. A large number of household expenditure surveys are being processed to provide improved estimates of the distribution of food consumption within a country. FAO's measures of undernourishment will also be complemented with a number of other indicators intended to better capture the multifaceted nature of food insecurity.

The process of revising FAO's methodology involves consultations with experts from around the world. The United States National Academy of Sciences held a workshop in February 2011 in Washington DC that provided many suggestions, as did a round table sponsored by the CFS held in Rome in September 2011. In addition, an International Scientific Symposium will be held in January 2012 in Rome. FAO considers such consultations essential for further improving the methodology used for the measurement of hunger. 


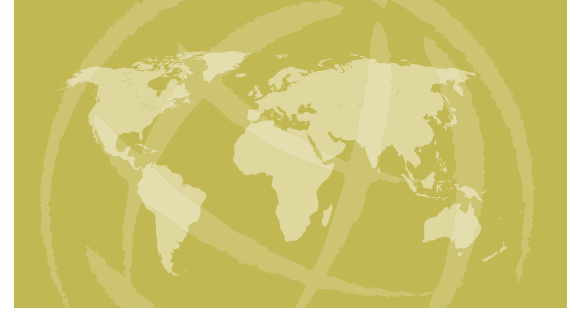

\section{Recent trends in world food commodity prices: costs and benefits}

\section{Past and future trends in world food prices}

\begin{abstract}
Key message
High and volatile food prices are likely to continue. Demand from consumers in rapidly growing economies will increase, population continues to grow, and any further growth in biofuels will place additional demands on the food system. On the supply side, there are challenges due to increasingly scarce natural resources in some regions, as well as declining rates of yield growth for some commodities. Food price volatility may increase because of stronger linkages between agricultural and energy markets, as well as an increased frequency of weather shocks.
\end{abstract}

\section{P} rices of food commodities on world markets, adjusted for inflation, declined substantially from the early 1960s to the early 2000s, when they reached a historic low (Figure 3). They increased slowly from 2003 to 2006 and then surged upwards from 2006 to the middle of 2008 before declining in the second half of that year. The sudden increases took many by surprise, and led to increased concern over the ability of the world food economy to adequately feed billions of people, now and in the future. Although various observers attach differing degrees of importance to assorted factors, there is a relatively strong consensus that multiple factors had a role in the price increases that began in 2003. ${ }^{3}$ These factors include:

- weather shocks, such as drought in Australia (2005-07), that reduced wheat production and trade;

- $\quad$ policies to promote use of biofuels (tariffs, subsidies and mandated levels of use) that increased demand for maize and vegetable oils;

- depreciation of the United States (US) dollar;

- longer-term economic growth in several large developing countries that (a) put upward pressure on prices for petroleum and fertilizer because of the resource-intensive nature of their economic growth and (b) led to increased demand for meat, and hence animal feed, as diets diversified;
- $\quad$ rising production costs (e.g. irrigation pumps, machinery) and transport costs as a result of higher prices for petroleum and fertilizer;

- slower growth of cereal yields (and production), especially those of rice and wheat, during the past 20 years as a result of low investment over the previous three decades;

- increased demand on commodity futures markets as a result of both speculation and portfolio diversification;

- low levels of stocks, caused in part by some of the factors noted above;

- trade policies, such as export bans and aggressive buying by governments, that encouraged producers to withhold supplies, traders to increase stocks and consumers to engage in panic buying.

\section{FIGURE 3}

Apart from a peak in the early 1970 s, the cost of food declined from the early 1960 s until 2002 , since when it has started an upward trend

\section{Index $(2002-04=100)$}

400

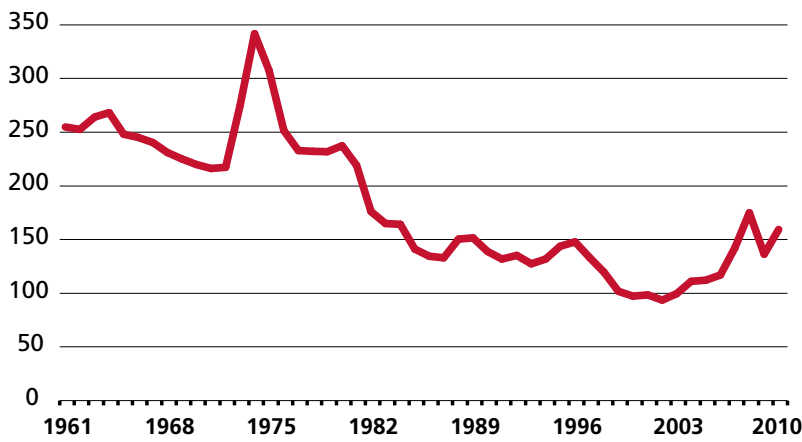

Note: FAO Food Price Index, adjusted for inflation, 1961-2010, calculated using international prices for cereals, oilseeds, meats, and dairy and sugar products. The official FAO Food Price Index has been calculated since only 1990; in this figure it has been extended back to 1961 using proxy price information. The index measures movements in international prices, using proxy price information. The index measures movements in international prices,
not domestic prices. The United States gross domestic product deflator is used to express the Food Price Index in real rather than nominal terms. Source: FAO. 
When prices declined in the second half of 2008, there was some hope that prices would stabilize, although probably at a higher level than before the surge. But in the middle of 2010 they again began to increase rapidly (Figure 3). This has renewed concerns over high prices, and has also brought price volatility to the fore; it seems that world food commodity prices may endure repeated episodes of ups and downs in the future.

Will higher prices and increased volatility continue in the future? In terms of price levels, many medium to long-term projection models suggest that food commodity prices will remain relatively high over the next decade or so. For example, the Organisation for Economic Co-operation and Development (OECD)-FAO Agricultural Outlook 2011-20204 projects that world prices for rice, wheat, maize and oilseeds in the five years from $2015 / 16$ to $2019 / 20$ will be higher in real terms by $40,27,48$ and 36 percent, respectively, than in the five years from 1998/99 to 2002/03.

Prices are generally expected to rise because continued population and economic growth will put upward pressure on demand, as will the anticipated increased use of biofuels (depending on biofuel policies and the price of oil). On the supply side, if oil prices continue to rise, agricultural production costs will increase, contributing to higher food prices. Natural resource constraints, especially climate change and the limited availability of productive land and water in some regions, pose substantial challenges to producing food at affordable prices. ${ }^{5}$ On a more positive note, there remains significant potential for raising crop productivity through new technologies and improved extension, as well as for reducing losses in the supply chain. However, these gains will not materialize without increased investment. There may also be potential for further land expansion in Africa, Central Asia, Latin America and Ukraine, but again this will depend on appropriate investment. Furthermore, land expansion may also have negative environmental consequences.

There are also compelling arguments suggesting that, in addition to being higher, food commodity prices will also be more volatile in the future. If the frequency of extreme weather events increases, production shocks will be more frequent, which will tend to make prices more volatile. Furthermore, biofuel policies have created new linkages between the price of oil and the price of food commodities. When oil prices increase, demand for biofuels will increase, thus raising food prices, with the opposite happening when oil prices decrease. ${ }^{6}$ Because world oil prices have historically been more volatile

$\mathrm{BO} \mathbf{1}$

Some key concepts: price levels, price volatility (variability) and unpredictability of prices

In analysing food prices, it is important to distinguish between several related, but different, concepts. One important distinction is that between average prices over time and variability (volatility ${ }^{1}$ ) of prices over time. It is possible for average prices to change without any change in variability. One simple way this might happen would be if a food-importing country were to impose a constant tariff on imports; the tariff would make food more expensive, but in most circumstances it would have no effect on the variability of domestic prices. Conversely, it is also possible to have a change in price variability with no change in the average level. This might happen, for example, if the weather became more variable but food production remained the same on average.

That being said, price levels and price volatility are related - they are both determined by supply and demand. In addition, high prices tend to be correlated with high volatility. Initially, high prices encourage people to draw down their stocks, which can moderate price changes that would otherwise have been caused by supply and demand shocks. However, once stocks have been drawn down, the system is vulnerable to a further supply or demand shock; the absence of the buffer means that price variation will tend to be greater than if stocks were available. Despite this relationship, it is still important to distinguish between the two concepts. For one, prices can be high but stable. For another, the costs and benefits of high prices are very different from the costs and benefits of volatile prices, as described in 'Costs and benefits of high and low food prices' and 'Costs and benefits of volatile and unpredictable prices').

Another crucial distinction is that between variability and unpredictability. Prices exhibit variability for many reasons, but some price changes may be largely predictable. The classic example of predictable changes in food prices is seasonality, whereby prices are lowest during and soon after harvest and highest immediately before harvest. While seasonal changes are not exactly constant from year to year, they are often similar from one year to the next. Weather shocks, on the other hand, are typically unpredictable and may lead to unpredictable changes in prices, especially if stocks are low to begin with. Therefore, some price changes are relatively easy to anticipate and others are much harder to predict. Predictable changes in prices have different costs and benefits than unpredictable changes.

\footnotetext{
${ }^{1}$ Variability, instability and volatility are used interchangeably in this report
} 


\section{How to measure price volatility}

The simplest way to measure price volatility is the coefficient of variation (CV). This is the standard deviation of prices over a particular time interval divided by the mean price over the same interval. One advantage of this measure is that it has no units. This makes it easy to compare, for example, domestic price volatility measured in different countries. However, the CV can create misleading impressions if there are strong trends in the data, because trend movements will be included in the calculation of volatility. Moreover, there is no universally accepted method for removing the trend component because different observers will have different ideas about the nature of the underlying trend (e.g. linear, quadratic).

As an alternative to the $C V$, economists often use the standard deviation of changes in the logarithm of prices. ${ }^{1}$ This also has no units, but is less affected by strong trends over time.

${ }^{1}$ C.L. Gilbert and C.W. Morgan. 2010. Review: Food price volatility Philosophical Transactions of the Royal Society B, 365: 3023-3034. than food prices, world food markets may also be subject to increased volatility. Increased participation (e.g. by pension funds) in financial markets that trade commodity index funds might also lead to increased volatility, although this is a hotly debated issue without a clear consensus.

While it is not possible to know with certainty the extent of future increases in either the level or volatility of prices, the risks of higher prices and greater volatility are sufficiently large to warrant serious efforts to understand what can be done to reduce the likelihood of increased prices or greater volatility, or to manage the consequences when these are unavoidable. In considering the most appropriate options to counter high and/ or volatile prices, however, it is important to remember that the level and volatility of prices are the outcome of various forces that affect supply and demand. Further, this report will stress that the causes and impacts of high and/or volatile prices are complex because they are highly context-specific, i.e. they depend on the commodity being considered, the specific factors (policies, exchange rates, import dependence) that affect price transmission in various circumstances, the demographic characteristics of households and their production and consumption patterns, and many other variables. Thus, a crucial message is that policy interventions should take into account the specific context in which they are meant to be applied.

\section{Key message}

In the short term, the benefits of high prices go primarily to farmers with a large marketed surplus, and these farmers are not the poorest of the poor. In addition, the poorest people usually buy more food than they sell. Thus, high food prices tend to worsen poverty, food insecurity and malnutrition. However, high prices represent an opportunity to spur long-term investment in agriculture, which will contribute to sustainable food security in the longer run.

Let us look first at the impacts of high (or low) price levels. The level of food commodity prices has two distinct types of effect. International market prices can affect macroeconomic variables at the national level, such as the balance of payments, budget deficits and exchange rates, while domestic prices affect the poverty, energy intake and nutrition of individuals. (The linkages between international and domestic prices are discussed in detail under 'Lessons from the world food crisis of 2006-08', pp. 21-31.)

\section{Macroeconomic impacts}

The macroeconomic impacts of commodity prices are important because they affect the level of per capita income, which ultimately is a key determinant of living standards for individuals and families.

Generally speaking, high international prices for food commodities benefit countries that export those products, while low prices benefit importing countries. Ignoring for the moment considerations of volatility, this is basically a zerosum game in the short-to-medium run: exporters benefit at 
the expense of importers, and vice versa. In the longer term, however, higher prices could cause some importing countries to invest in their agriculture and reduce imports, or even become exporters. Such investment is crucial for the development of the agriculture sector and sustainable reductions in poverty and food insecurity.

The effects on the balance of payments and the exchange rate will be strongest for countries for which food trade is a substantial share of exports or imports. Countries that export a large proportion of their production benefit the most when prices are high. Countries that import a large share of the food they consume are hurt the most by high prices. However, terms-of-trade effects are also important. For example, a country that exports oil or metals may not need to produce more of those products to offset higher food prices if the price for their exports increases by more than the price of food imports.

In terms of fiscal effects, the impact of higher food prices will be strongest in countries where food subsidies are an important part of the budget. For importers, the cost of higher prices will have a direct fiscal impact if the subsidies not only continue but are increased to offset the higher prices. But even for exporting countries that subsidize domestic consumption, there will be an important impact in opportunity cost terms. In both of these cases, high levels of subsidies can reduce funds available for investment in public goods such as agricultural research, education, health and roads. Reduced expenditure on these items can reduce longterm economic growth; and this has indeed happened in Latin America. ${ }^{7}$

\section{Household-level impacts}

Poor people spend a large majority of their income on food (Figure 4), while many farmers derive much of their income from producing food. This suggests that changes in food prices will have large effects on the welfare of both farmers and poorer consumers.

In order to understand the importance of higher food prices for welfare, poverty and food security, it is important to distinguish between net food sellers and net food buyers. A net food seller is someone for whom the total value of the food they produce exceeds the total value of the food they consume, whereas for a net food buyer the reverse is true. Net food buyers will generally be hurt by higher food prices, while net food sellers will benefit (see Box 3).

The concepts of net food seller and net food buyer are quite distinct from whether the household is rural or urban. Nearly all urban dwellers are net food buyers; perhaps surprisingly, most rural dwellers also are net food buyers. Very-small-scale farmers and agricultural labourers are often net purchasers of food as they do not produce enough food for their families. They thus need to purchase food from the market and are likely to benefit from lower prices (but see

\section{FIGURE 4}

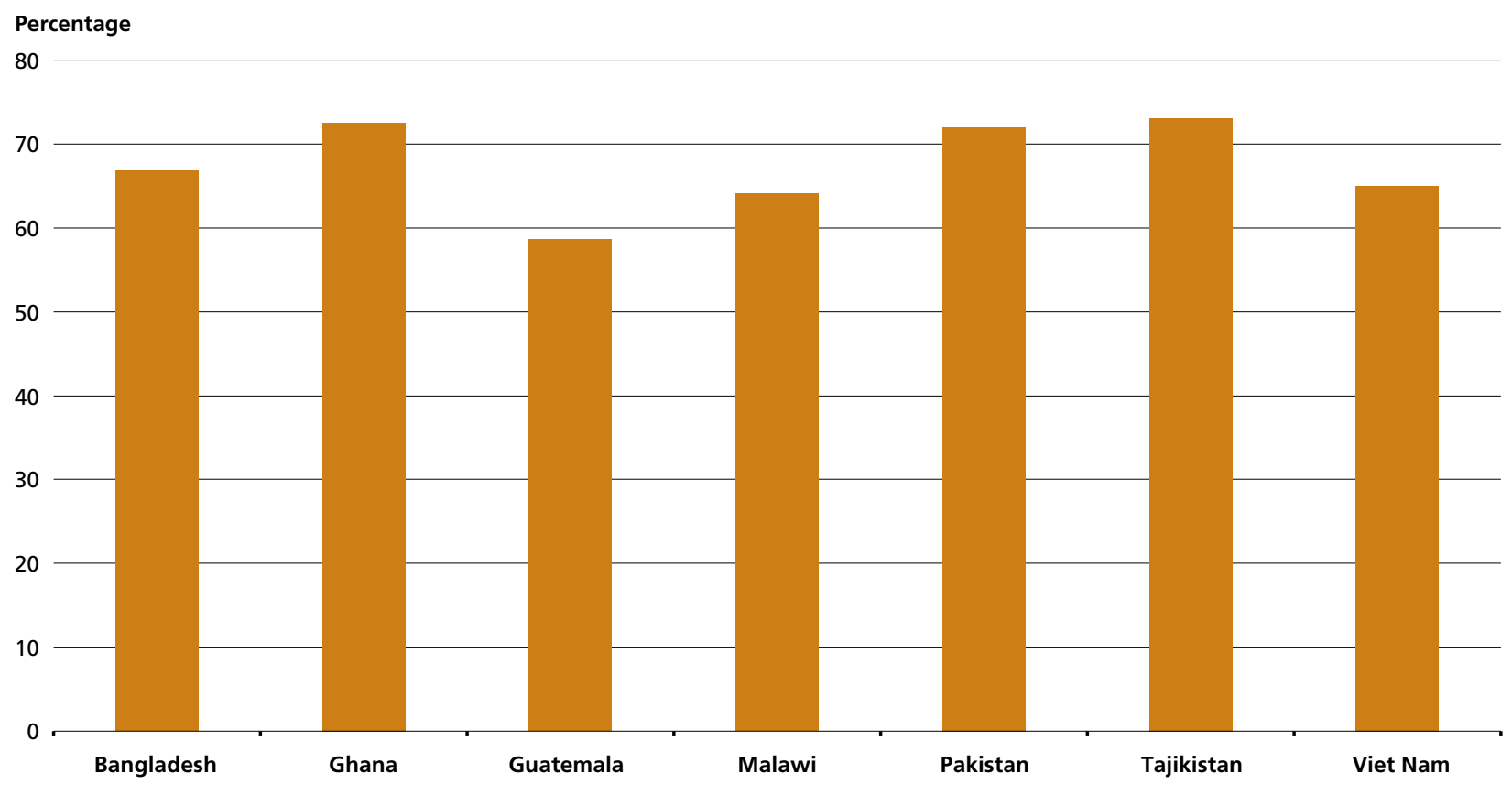

Note: Percentage of household budget spent on food by the lowest expenditure quintile of the population Source of raw data: FAO Rural Income Generating Activities project. 


\section{Net food sellers and buyers}

The concepts of net food seller and net food buyer at the household level are exactly analogous to the concepts of net food exporters and importers at the country level. The status of any particular household is determined by subtracting the value of food consumed (including from its own production) from the value of food produced. ${ }^{1}$ This calculation implicitly takes into account marketing costs and seasonality by valuing production at farmgate prices and consumption at retail prices. For example, a household may be a net seller of food during harvest time and a net buyer at other times. Furthermore, on an annual basis a household might actually produce more than it consumes in quantity terms but it could still be a net food buyer if it sells the entire crop at harvest and buys back from the market later, because retail prices are higher than farmgate prices.

It is also true that whether a given household is a net food seller or buyer may depend on the overall level of market prices. Higher prices will discourage consumption, encourage more production and possibly convert some households from net buyers to net sellers. Lower prices could do the opposite. However, it should be noted that these 'second round effects' are typically marginal in their impact - a household might switch from being a small net buyer to a small net seller but not to a large net seller. ${ }^{2}$ Indeed accounting for this phenomenon has been found to have only minor effects on the poverty impacts of higher prices. ${ }^{3}$

This methodology of evaluating the impact of price changes on the basis of whether a household is a net food buyer or seller can be used to assess the impact of changes in food prices, but not the impact of simultaneous changes in food and input (e.g. fertilizer) prices. If fertilizer prices increase at the same time that food prices increase, the net impact on farmers will need to be assessed using data on production costs (see 'Do fertilizer price increases cancel out farm price increases?', pp. 29-31 for further discussion of this issue).

\footnotetext{
N. Minot and F. Goletti. 1998. Rice export liberalization and welfare in Vietnam. American Journal of Agricultural Economics, 80(4): 738-749. 2 Ibid.

${ }^{3}$ A. Zezza, B. Davis, C. Azzarri, K. Covarrubias, L. Tasciotti and G. Anríquez. 2008. The impact of rising food prices on the poor. ESA Working Paper 08-07. Rome, FAO (available at ftp://ftp.fao.org/docrep/ fao/011/aj284e/aj284e00.pdf).
}

below for a discussion of the possible impact of higher food prices on rural wages, which are typically an important source of income for the landless). These landless or landpoor rural households are often the poorest of the poor, and a disproportionately large proportion of such households are headed by women.

In urban areas, higher food prices may substantially hurt the poor because, typically, little food is produced in such areas and because food typically accounts for a large share of expenditures for the poor. In order to cope with the reduction in disposable income resulting from higher food prices, households will engage in new economic activities, sell assets or borrow in order to mitigate the decline in consumption. They also commonly reduce expenditures on health and education and shift dietary patterns towards cheaper (starchy) foods and away from micronutrient-rich foods such as milk, meat, and fruits and vegetables. ${ }^{8}$ Energy intake will also decline in cases where people are so poor that they simply cannot afford the same amount of calories at the new higher prices.

In rural areas, higher food prices will tend to have smaller negative effects on net food buyers because many households produce a substantial share of what they consume, and hence are only marginal food buyers. On the other hand, farmers who are net food sellers are likely to benefit from higher prices, which, other things being equal, will tend to increase their income. Since many farmers are poor, higher prices could help to alleviate poverty and improve food security. However, it must also be kept in mind that farmers with more surplus production to sell will benefit more from high prices than farmers who have only a small surplus to sell. Further, in most (but not all) contexts, farmers with more land tend to be better off than farmers with only a little land, so it may be that poorer farmers will not receive the bulk of the benefits from higher food prices. Overall beneficial impacts of higher food prices on poverty are more likely in countries with a relatively equal distribution of land.

Another potentially important effect of food prices on poverty and food security operates through labour markets and wages. Higher food prices stimulate demand for unskilled labour to work on farms, which might result in an increase in rural wages in the long run. This would benefit households that are dependent on wage labour for their income (who are usually very poor). The evidence in this regard is inconclusive, however, and depends on the importance of agriculture in the overall economy and how many years the adjustments in wages take. ${ }^{9}$ The labourmarket channel is worthy of more study, as there is scant information available concerning its effects on poverty and food security. 
Given these considerations, what does the evidence show about the impact of high prices on poverty? The average income of net food buyers is higher than that of net food sellers in most developing countries, and thus high food prices would transfer income from higher-income people to those with lower income. ${ }^{10}$ But this conclusion results from dividing the population into just two groups; studies that use a more detailed disaggregation nearly always show that the poorest 20 percent of the population are net food buyers, with surplus-producing farmers somewhere in the middle of the income distribution. For example, higher food prices increased poverty in seven of nine countries studied, with Peru and Viet Nam being the only exceptions. ${ }^{11}$ Viet Nam is a substantial rice exporter with relatively equitable land distribution; as a result it has many households that produce a surplus of rice but that are still relatively poor. In Peru, the beneficial impact was very small. In all other countries in the sample (Bolivia, Cambodia, Madagascar, Malawi, Nicaragua, Pakistan and Zambia), higher prices increased poverty, even after taking account of increased labour demand. Another study reached similar conclusions - the poor were hurt by higher prices in all countries studied (Albania, Bangladesh, Ghana, Guatemala, Malawi, Nepal, Nicaragua, Pakistan, Panama, Tajikistan and Viet Nam), with the exception of rural dwellers in Viet Nam. ${ }^{12}$ This study did not examine labourmarket effects, but did incorporate supply and demand responses, and found that high prices still hurt the poor.
Higher prices also increased poverty in Guatemala, Honduras, Nicaragua and Peru..$^{13}$ A review of a large number of studies pertaining to rice (including Indonesia, the Philippines and Thailand) found that the poorest quintile of the population is nearly always a net purchaser of rice. ${ }^{14}$ Taken together, these studies show that the poorest 20 percent of the population are net food sellers only in unusual circumstances. ${ }^{15}$

Different types of studies provide further support for the idea that high food prices hurt the poor, and in more ways than just pushing them below the poverty line. Generally speaking, energy intake is less affected than dietary diversity and consumption of protein and micronutrients. As one example, when rice prices increased in Indonesia during the Asian financial crisis in the late 1990s, households reduced purchases of more nutritious foods such as eggs and green leafy vegetables in order to continue to buy rice. ${ }^{16}$ This led to a measurable decline in blood haemoglobin levels in young children (and in their mothers), thus increasing the probability of developmental damage. In addition, mothers in poor families responded by reducing their caloric intake in order to feed their children better, leading to an increase in maternal wasting. A negative correlation between rice prices and nutritional status has also been observed in Bangladesh. ${ }^{17}$ Height for age scores among children under three years old in El Salvador declined during the 2006-08 food crisis, although the effects were mitigated to some

\section{BOX 4}

\section{Forests and food security}

Global forest area is around 4 billion hectares, and still represents about 30 percent of the total terrestrial surface of our planet. ${ }^{1}$ It is well known that forests provide many key environmental services, such as water management, conservation of biodiversity and serving as a carbon sink to mitigate global warming. In addition, forests play an important role in the food security of one billion of the poorest people on the planet by providing food or cash income through a wide range of products such as wild yams, bush meat, edible insects, fruits, leaves, mushrooms, nuts, honey and medicinal products. Forests also provide many non-food raw materials such as bamboo, rattan, palm fibres and resins that can be used for building shelter or sold at local markets, as well as fodder for livestock. ${ }^{2}$

The people who depend on forests for their food security are often very vulnerable to higher food prices because they purchase most of their food on markets. Higher food prices for these "hunters and gatherers" mean that they have to collect more out of the forests either for sale at local markets (in order to obtain sufficient cash to buy the more expensive food), or to exchange via barter. Higher food prices can thus have a direct impact on forest quality, conservation and the survival of key forest species (mainly fauna and medicinal plants).

For these people, farming is not an option, as they do not own or have access to farmland. In view of concerns about climate change and biodiversity losses, clearing more forests is not an attractive alternative either. Thus, sustainable forest management is critical for their food security. Forests will increasingly need to be managed not only for their timber production potential, but also to produce a larger and sustainable supply of edible nonwood forest products, as well as to enhance the many services forests and trees provide to the agriculture sector.

${ }^{1}$ FAO. 2010. Global Forest Resources Assessment 2010. Rome.

2 For further information, see http://www.fao.org/forestry/nwfp/en/. 


\section{Why are there now so many concerns about high prices, after years of concern about low prices?}

Before the recent world food and financial crises, many observers complained that low world food prices were a problem for poor people in developing countries. More recently, however, after the surge in food prices, most analyses claim that higher food prices increase poverty. How can high prices and low prices both be bad for poverty? ${ }^{1}$

One possible way to reconcile these contrasting views on high and low prices would be to distinguish between the long-run and the short-run effects of prices. In the short run, higher prices increase poverty because the poorest 20 percent of the population in most countries are net food buyers. But, if public and private long-term investment increase as a result of higher food prices, this increased investment might raise productivity and contribute to economic growth and poverty alleviation. However, such a beneficial outcome will not arise from a short-term supply response that is due to increased use of labour and raw material inputs such as fertilizer and pesticides.

Another issue to consider is that many of the gains from higher world prices would go to large landowners in uppermiddle-income exporting countries - but these farmers are not poor. Thus, even if developing countries gain from higher prices, this does not mean that poverty will be reduced - a more disaggregated analysis that examines the impacts on land values and wages in specific countries is required as well as a careful disaggregation of expenditure patterns by income class.

It is also important to realize that the availability and analysis of household survey data has increased substantially in the past few years and this is responsible for some of the shift in perspective surrounding high and low prices. Furthermore, some of the concern over high and low prices is more accurately described as concern over price volatility; sharp fluctuations in prices can be bad for both farmers and consumers (see 'Costs and benefits of volatile and unpredictable prices', below).

Some studies appear to support the idea that higher prices have beneficial effects by showing that, for example, agricultural trade liberalization would both reduce poverty and raise world food prices. But a careful reading of some of these studies ${ }^{2}$ shows a more nuanced picture. First, it is increased access to protected markets that reduces poverty, not higher world food prices. ${ }^{3}$ Second, higher world prices do not necessarily mean higher domestic prices, and it is the latter that affects poverty rates. Thus, a reduction in import barriers would lower domestic prices and raise world prices at the same time (through increased demand for imports). The lower domestic prices would reduce poverty, even though world prices would have increased. In other words, higher world agricultural prices and reduced poverty are two separate outcomes of trade liberalization - high food prices do not reduce poverty.

\footnotetext{
${ }^{1}$ D. Rodrik. 2008. Food prices and poverty? Confusion or obfuscation? (available at http://rodrik.typepad.com/dani_rodriks_weblog/2008/05/foodprices-and.html); J. Swinnen. 2010. The right price of food: reflections on the political economy of policy analysis and communication. LICOS Discussion Paper 259. Leuven, Belgium, LICOS Centre for Institutions and Economic Performance, Katholieke Universiteit Leuven.

2 See, for example, T.W. Hertel, R. Keeney, M. Ivanic and L.A. Winters. 2006. Distributional effects of WTO agricultural reforms in rich and poor countries. World Bank Policy Research Working Paper 4060. Washington, DC, The World Bank.

${ }^{3}$ T.W. Hertel and W. Martin. 2008. Response to Dani Rodrik's blog post entitled 'Food prices and poverty? Confusion or obfuscation?' (available at http://rodrik.typepad.com/dani_rodriks_weblog/2008/05/food-prices-and. html).
}

extent for families with access to remittances from family members overseas. ${ }^{18}$ Weight for age did not decrease, suggesting that there was a decrease in consumption of key nutrients but not in energy intake. In some situations, though, even energy intake may decline, in addition to dietary diversity. ${ }^{19}$

Furthermore, high food prices seem to have a disproportionate negative impact on female-headed households, for two reasons. ${ }^{20}$ First, these households tend to have less access to land and other resources, often because of customary laws and social discrimination; as a result, they are less likely to be net sellers of food. Second, these households also tend to be poorer, which means they spend a larger share of their income on food and are more affected by high prices.
In addition to affecting different types of households differently, changes in food prices also affect different household members differently. For example, women's participation in the labour force may increase substantially during economic crises, ${ }^{21}$ such as when males migrate in search of better employment. ${ }^{22}$ The resultant additional workload places stress on the time they have available to engage in household work and child care. ${ }^{23}$ The mortality of infant girls also increases more than that of infant boys during crises. ${ }^{24}$

While high food prices harm the poor in most cases, this is not an argument for generalized price subsidies. Such subsidies are often politically difficult to remove and can drain government budgets of the funds needed for investment in public goods such as agricultural research, rural roads, 
education, health and sanitation. Generalized price subsidies are also generally regressive, in the sense that most of the benefits are captured by the well-to-do, who, despite spending a smaller proportion of their budget on food than do the poor, spend more money on food in total than do the poor.

But if general subsidies are not the answer, what is the best way to help mitigate the adverse effects of high food prices? In the short term, one option is to target food safety nets to the most vulnerable (see 'Coping with price volatility after the fact: targeted safety nets and emergency food reserves', pp. 39-41). Over the longer term, the best way to lower food prices is to invest in agriculture; this will sustainably increase yields, reduce input costs, increase productivity and reduce food losses and waste. These investments have the potential to make food more affordable for consumers and more profitable for farmers, and are the only way to manage food prices in a way that benefits everyone. In this sense, the cure for high prices may be high prices, provided that the high prices motivate farmers to adopt improved technologies and national governments and international donors to increase the financial resources available for investment in agriculture (see 'Preventing price volatility in the long term: increasing the productivity, sustainability and resilience of agriculture', pp. 42-3). Thus, while high prices make the problem of food insecurity and poverty worse in the short run, they also represent an opportunity for investment and growth that can reduce food insecurity and poverty in the long run.

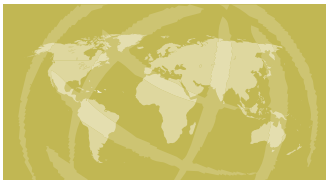

\section{Costs and benefits of volatile and unpredictable prices}

\section{Key message}

When prices fluctuate substantially, even if they are tolerable on average, the short-term shocks make both smallholder farmers and poor consumers vulnerable to long-term poverty traps. In addition, smallholder farmers find it difficult to invest when price changes are unpredictable.

In addition to the impacts of high or low food prices discussed above, variability in food prices can also have important effects even if average prices remain constant. This might happen if fluctuations in food production become more common or larger but average production remains the same. This would lead to more frequent and larger price changes, which might be predictable or unpredictable. If the increased variability were largely predictable, this would cause fewer problems than if the changes were unpredictable. However, price changes are generally less predictable than might be imagined. For example, even in the case of seasonality, the classic example of predictable food price changes, the month with the highest and lowest prices may vary substantially from year to year. ${ }^{25}$

Furthermore, even perfectly predictable changes in prices can cause problems for poor households that are unable to borrow when prices are high and thus are unable to 'smooth' their consumption over time. Thus, in Asia, where seasonal price changes are relatively more predictable than in Africa, there is still widespread concern over the ability of poor households to cope during the lean season immediately before harvest, despite the fact that this lean season is very predictable. Thus, although the focus in the rest of this section is on price changes that are unpredictable, predictable price changes can also impose significant costs on the poor.

Before discussing some of the negative impacts of price volatility, it may be helpful to point out that, at least in theory and under certain circumstances, volatile prices might actually benefit certain people, even if the price changes are not predictable. For example, rich consumers who can buy in bulk when food prices are low and then store the food for later use are able to buy more food when prices are low and less when prices are high, thus paying, on average, a lower price for food. Another example would be those people who can afford to buy the assets that poorer households sell at very low prices when desperate for funds or faced with natural disasters such as drought. ${ }^{26}$ In general, however, the costs of unstable and unpredictable prices would seem to far outweigh any benefits such as these, especially for the poor and food-insecure.

Broadly speaking, unpredictable price movements have at least four types of negative impact: poverty traps and reduced farm-level investment at the microeconomic level; macroeconomic impacts; and impacts on political processes (see Table 1). This report focuses on the microeconomic, household-level impacts. ${ }^{27}$

\section{Poverty traps}

Increased price unpredictability will mean a greater incidence of high prices, although there will also be a greater incidence of low prices if the average price remains the same. Nevertheless, there are situations in which periods of high prices can cause effects on net food buyers that are 


\begin{tabular}{lll} 
Channel & Who/what is affected? & Examples \\
\hline Poverty traps & Consumers and farmers & $\begin{array}{l}\text { Temporary coping mechanisms such as distress } \\
\text { asset sales or reduced intake of nutritious foods } \\
\text { leading to permanent effects }\end{array}$ \\
\hline Reduced private farm-level investment & Farmers & Lower fertilizer use leading to lower productivity \\
\hline Macroeconomic impacts & $\begin{array}{l}\text { Volatile food prices reduce the ability of prices to } \\
\text { function as signals that guide resource allocation }\end{array}$ & $\begin{array}{l}\text { Investment not directed to optimal sectors of the } \\
\text { economy, reducing economic growth }\end{array}$ \\
\hline Political processes & $\begin{array}{l}\text { Democratic institutions; long-term economic } \\
\text { growth }\end{array}$ & $\begin{array}{l}\text { Food riots that damage investment climate; } \\
\text { subsidies that prevent investment in public goods }\end{array}$
\end{tabular}

not reversed by periods of low prices. Similarly, periods of low prices can have adverse effects on farm families that are not reversed by periods of high prices. For example, if staple food prices increase sharply during the first 1000 days of a child's life, intake of more nutritious foods may be curtailed. This can cause permanent reductions in the child's health and nutritional well-being, which can result in lower productivity during adulthood. Suboptimal nutrition can also result in increased susceptibility to HIV-AIDS. ${ }^{28}$ In these cases, a subsequent period of low prices will not undo the damage. For net food sellers, periods of low prices will temporarily reduce income, causing similar effects to those experienced by net food buyers during periods of high prices. In these cases, the effects will not be reversed by a subsequent period of high prices.

Temporary reductions in disposable income due to price shocks can also lead families to draw down on their capital. For example, households may engage in distress sales of land or livestock in order to maintain food intake in the face of an economic shock, although this will depend on the situation in Burkina Faso, for example, during a severe drought households cut back on consumption in preference to selling livestock. ${ }^{29}$ Alternatively, families may make fewer visits to the doctor, or remove children from school in order to save on school fees. In Burkina Faso school enrolment is negatively affected by shocks such as drought, and a shock to cocoa prices led to a similar decline in Côte d'Ivoire. ${ }^{30}$ In Nicaragua, sick children in areas affected by Hurricane Mitch in 1998 made fewer visits to the doctor than children in areas not touched by the storm. ${ }^{31}$ These responses may result in a loss of human capital in the affected households.

Such episodes can result in poverty traps, whereby a onetime shock has permanent effects. Poverty traps can be caused by any of a wide range of factors - natural disasters such as hurricanes or droughts, an economic slowdown or adverse price shocks. Regardless of the ultimate cause, any reduction in the purchasing power of the poor can have similar effects.

During Zimbabwe's drought in the mid-1990s, young children living in the poorest households suffered a substantial reduction in growth rate, and these children remained shorter than would otherwise be expected several years later. ${ }^{32}$ These effects are particularly worrisome because a large body of literature suggests that stunting is associated with reduced cognitive skills and slower progress in school as a child, as well as reduced earnings as an adult. ${ }^{33}$ In Indonesia, lower rainfall in the year of birth significantly reduced attained adult height of women, their number of years of schooling as well as their adult earnings and led to poorer adult health. ${ }^{34}$ There is evidence of such poverty traps due to drought in Ethiopia and a hurricane in Honduras. ${ }^{35}$ What all of these studies have in common is that they show how a one-time shock can have permanent effects.

\section{Reduced farm-level investment}

The second type of negative impact of unpredictable prices relates to farm-level investment decisions in developing country settings where credit markets do not function well and income is highly variable due to fluctuating weather conditions or volatile prices. If farmers cannot obtain credit when they need it, they will be reluctant to make productive investments, ${ }^{36}$ especially those that tie up capital for extended periods of time. This may happen even when prices are stable, but price volatility will exacerbate this effect. For example, in India, farmers underinvest in bullocks due to volatility in income. ${ }^{37}$ Other fundamental decisions, such as choice of crop, also may be affected by price volatility; for example, poor farmers in the Punjab region of Pakistan switched from growing Basmati rice, which is relatively profitable, to growing livestock fodder in an effort to avoid price (and yield) risk. ${ }^{38}$ And even investments in fertilizer use, which offer returns over a relatively short period of time, seem to be negatively affected in some situations; for example, in Ethiopia farmers were reluctant to invest in fertilizer for fear that they would be hit by an economic shock. ${ }^{39}$

Because poor smallholder farmers are afraid that an adverse price shock might lead them into the type of poverty trap discussed above, they may be reluctant to adopt technologies that provide greater long-run returns. Thus, 
they adopt a low-risk, low-return strategy that may be optimal given their aversion to risk (which is due at least partially to their poverty), but slows down the long-term development process. Similarly, because much investment is irreversible or involves sunk costs, investors will tend to reduce investment in an environment of highly unpredictable prices.

\section{Price volatility for staple foods in developing countries is particularly harmful}

Unstable prices for staple foods are likely to have larger negative effects than unstable prices for other agricultural commodities because staple foods are important for both poor farmers and poor consumers. On the consumer side, staple foods account for a large share of the expenditures of the poor. On the producer side, they are the most widely planted crops in developing countries, especially on smallholdings.

Typical staple foods include rice, wheat, maize, millet, cassava and potatoes, but there may be other crops that are considered staples as well (e.g. onions in India, chilli peppers in Indonesia). The share of these spices in household budgets is much smaller than that of cereals and root crops but price changes can be much larger, resulting in a large impact on disposable income. For most cash crops (e.g. coffee, cocoa), on the other hand, unstable prices have little impact on consumers in developing countries. While perennial crops such as oil palm are food commodities, the budget share of these commodities is much smaller than that of staple foods. This is not to say that volatility of prices for these crops is unimportant for the welfare of the poor, only that it is probably less important than volatility of prices for staple foods.

Unstable prices for staple foods are also likely to have greater effects in very-low-income countries than in higherincome countries and in poor households than in better-off households along all four of the dimensions in Table 1. There are two key reasons for this. First, in poor countries food accounts for a larger share of consumer spending, farm production and the macroeconomy and hence has more impact on political processes than in rich countries. Second, the poor have fewer assets than the rich, and are thus less able to avoid or cope with price volatility. The corollary is that, as economies grow and develop, stable food prices become less and less important for investment and growth: consumers diversify their diets, producers shift into highervalue crops, and as families move off the farm the macroeconomy becomes more diversified.

But the fact that the costs of unstable prices are greater than the benefits does not necessarily imply that instability should be reduced. Before making this assertion, the costs of unstable and unpredictable prices must be compared with the costs of reducing that instability or of mitigating its impacts. Such a comparison of costs is of paramount importance when analysing the policy options discussed under 'Policy options to address price volatility and high prices', pp. 32-43. 


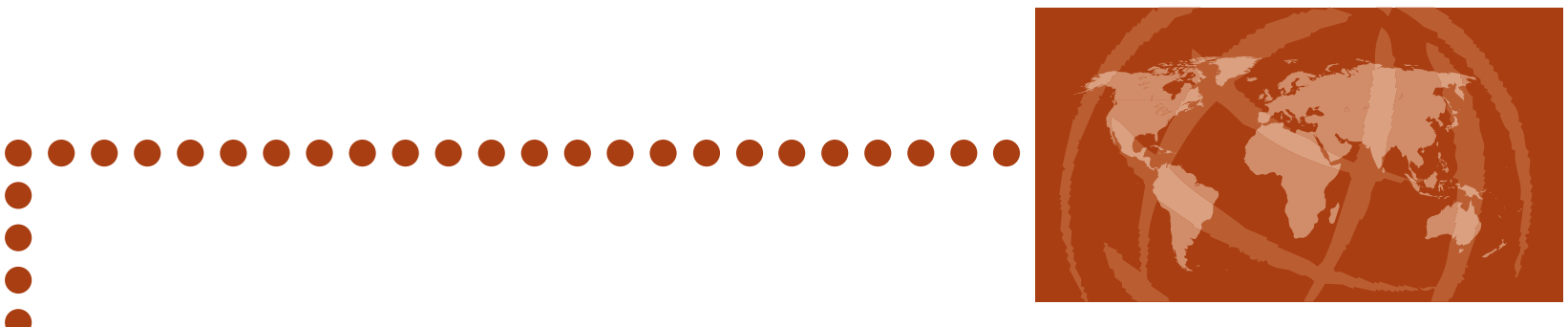

\section{Lessons from the world food crisis of 2006-08}

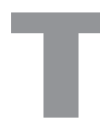

here has been substantial discussion of what happened (and why) on world food markets between 2006 and 2008 (and more recently, in 2010 and 2011). The OECD-FAO Agricultural Outlook provides a review of these events. ${ }^{40}$ But the degree to which world price movements are transmitted to domestic prices is a critical issue, because neither farmers nor consumers interact directly with world markets. In other words, the impacts of world prices (in terms of both levels and volatility) on poverty and food security are mediated through the price transmission mechanism. This section of the report focuses on what happened to prices on domestic markets during the world food crisis of 2006-08.

\section{How have domestic prices for staple foods changed since 2006?}

\section{Key message}

Domestic food prices increased substantially in most countries during the world food crisis; the exceptions were some large countries that were able to insulate themselves from world markets. But trade insulation increased prices and volatility in international markets, making domestic price increases in small import-dependent countries larger than they otherwise would have been.

The world witnessed large increases in the prices of rice, wheat and maize on international markets during the food crisis of 2006-08. In most cases, the surges in prices on international markets led to substantial increases in domestic prices, although domestic prices did not increase in some countries (see 'What is the impact of trade policies on price transmission?', pp. 22-4). By July 2008, domestic rice, wheat and maize prices were each, on average across countries, about 40 percent higher (after adjusting for inflation) than they were in January 2007 (Figure 5). Other studies have also reached the conclusion that there was substantial transmission of prices from world markets to domestic markets during the crisis. ${ }^{41}$ While transmission is often weak in normal times, transmission was stronger during the world food crisis. ${ }^{42}$

Using annual averages, in 2008 domestic prices (adjusted for inflation) in the same sample of countries as used in Figure 5 were on average 28, 26 and 26 percent higher for rice, wheat and maize, respectively, than in 2007. Although much less than the changes experienced on world markets, these increases would have had a substantial impact on the purchasing power of the poor. In countries such as Bangladesh, Malawi and Viet Nam, the poor often spend 35 percent or more of their income on staple foods; since total food is about 70 percent of total expenditures for the bottom quintile (see Figure 4, p. 14) staple foods thus account for about half of total food expenditures for the poorest 20 percent of the population. Thus, in 2008, poor consumers who did not produce

\section{FIGURE 5}

Domestic prices for rice, wheat and maize increased substantially during the crisis

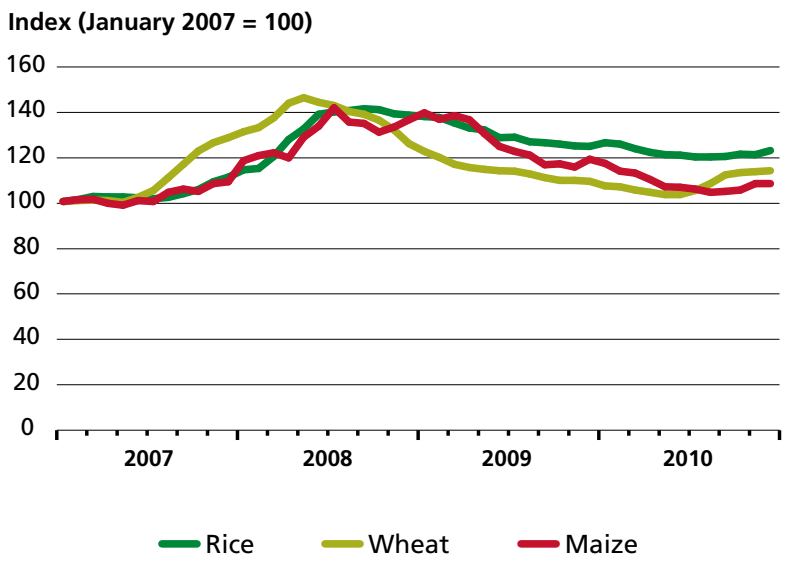

Note: The graph shows average inflation-adjusted trends in domestic prices for rice, wheat and maize across countries from January 2007 to December 2010. The domestic price is set equal to 100 in January 2007 for all countries, and the index value for subsequent months is equal to the average index value across all countries. The domestic price indices for rice, wheat and maize include 42,27 and 34 countries, respectively, and include all countries for which data were available at the time of writing Source of raw data: FAO Global Information and Early Warninq System. 


\section{FIGURE 6}

Volatility of domestic prices for rice, wheat and maize peaked in 2008

Average volatility of domestic prices (percent)

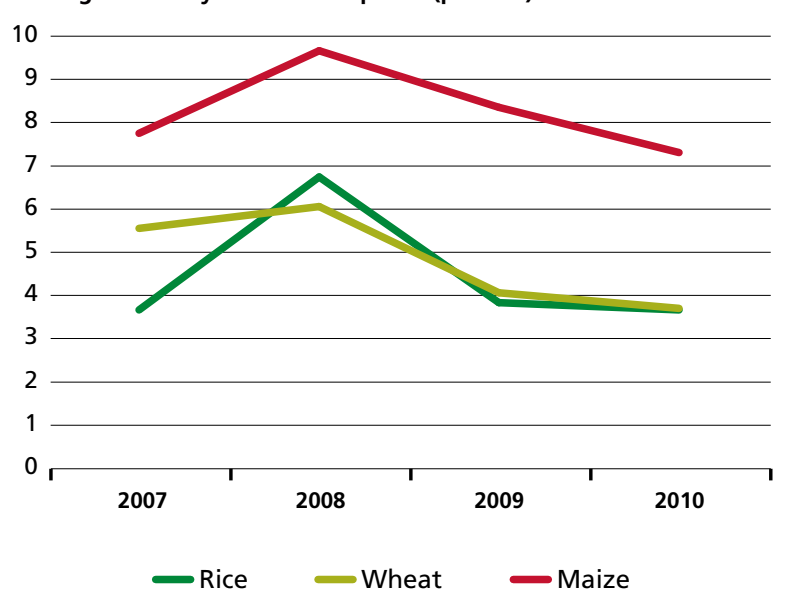

Note: Volatility of domestic prices is calculated as the standard deviation of the logarithm of $(P, P)$, using monthly data. Countries included are the same as those in Figure 5 . of $\left(\mathrm{P}_{t} / \mathrm{P}_{\mathrm{t}-1}\right)$, using monthly data. Countries included are the same as those
Source of raw data: FAO Global Information and Early Warning System.

staple foods experienced a decline in real income of approximately 9 percent (equal to the budget share of 35 percent multiplied by the price increase of about 26 percent). Not surprisingly, the average volatility of domestic prices also increased during the crisis, reaching a peak for all three cereals in 2008 (Figure 6).

After the collapse of international cereal prices in the second half of 2008, domestic prices eventually began to decline in most countries. By the second quarter of 2010, domestic prices (after adjusting for inflation) had largely returned to January 2007 levels for wheat and maize. Domestic rice prices remained at somewhat higher levels, however, with prices on average 20 percent higher than in January 2007. The pattern of changes in domestic prices across cereals was similar to that on world markets, as world rice prices increased the most between January 2007 and the second quarter of 2010.

In the second half of 2010 and the first half of 2011, however, world prices for wheat and maize doubled due to wheat crop damage in the Russian Federation and a subsequent export ban, as well as poor growing conditions for the maize crop in the United States of America and a weakening dollar. Notably, world rice prices were much more stable during this period. Transmission of these shocks to domestic markets varied from country to country, although it is too early to draw general conclusions. The next section of the report describes the conditions under which world price shocks are transmitted to domestic economies, as well as how trade can mitigate the impact of domestic supply shocks on price volatility.

\section{What is the impact of trade policies on price} transmission?

\section{Key message}

Restrictive trade policies can protect domestic prices from world market volatility but can also result in increased volatility as a result of domestic supply shocks. In many instances, unpredictable government policies are a more important cause of domestic price volatility than world market price fluctuations.

Price transmission from world markets to domestic markets is affected by several factors, including transport costs, countries' levels of self-sufficiency, exchange rates and domestic shocks. But trade policy is perhaps the most fundamental determinant of the extent to which world price shocks pass through to domestic markets. Trade policy interventions were relatively common in developing countries during the world food crisis, with at least 55 countries using trade policy instruments to mitigate the impacts of the world food crisis of 2006-08. ${ }^{43}$

In particular, the key factor that affects price transmission is the degree to which the government determines the volume of trade (either exports or imports), as opposed to allowing the private sector to make the decision. Government control might be applied formally, through a fixed quota, or informally, through ad-hoc determination of quotas that vary in response to external events. Export quotas can reduce pass-through of high world prices to the domestic economy, while import quotas can prevent the pass-through of very low world prices.

For example, during the world food crisis of 2006-08, domestic prices of rice and wheat were very stable in China, India and Indonesia because of government controls on exports of these crops (see Figure 7 for China)..$^{44}$ These controls are in place even in normal times and were not implemented specifically in response to the crisis. It is important to note that while trade controls in China did prevent transmission from world markets, China has maintained a generally open trade policy in the sense that domestic rice prices are at most times similar to those on world markets - the government does not systematically force domestic rice prices to be above or below world prices. On the other hand, domestic prices of soybean in China surged in 2007 and 2008, because the government does not control trade in that commodity (Figure 8). In addition, China imports a large share of the soybean it consumes, so export restrictions would be irrelevant.

Of course, not all government trade controls lead to more stable and predictable prices (Box 6). Malawi, for example, arranged for exports of maize in 2007/08 and 2008/09, but domestic supplies were not sufficient to support exports and 
domestic prices surged. In 2005, Zambia did not correctly anticipate the domestic supply of maize and was late in issuing import licences. Once the licences were issued, there was confusion about the level of import tariff to be applied, with disagreements among branches of government. After the issue of the tariff was clarified, new sanitary and phytosanitary regulations were introduced, which created

\section{FIGURE 7}

Government control of trade in rice prevented high world market prices from affecting domestic prices in China during the 2006-08 food crisis

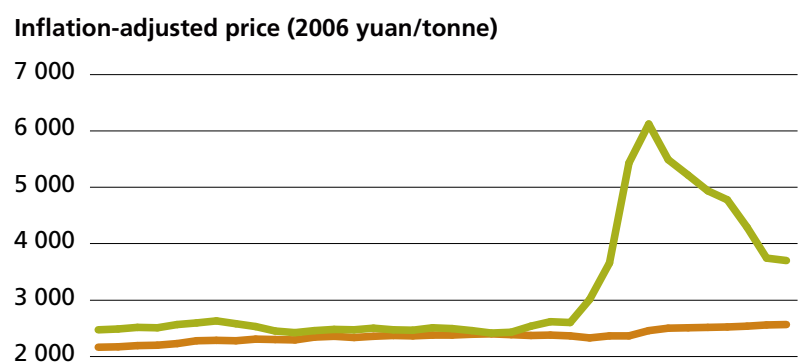

1000

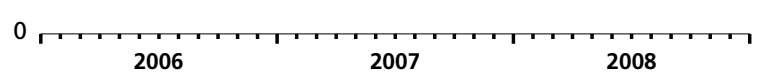

Domestic prices $\longrightarrow$ World prices

Source: C. Fang. 2010. How China stabilized grain prices during the global price crisis. In D. Dawe, ed. The rice crisis: markets, policies and food security. London, Earthscan and Rome, FAO.

\section{FIGURE 8}

The Chinese government does not control trade in soybean, and domestic prices follow world market prices

Inflation-adjusted price (2006 yuan/tonne)

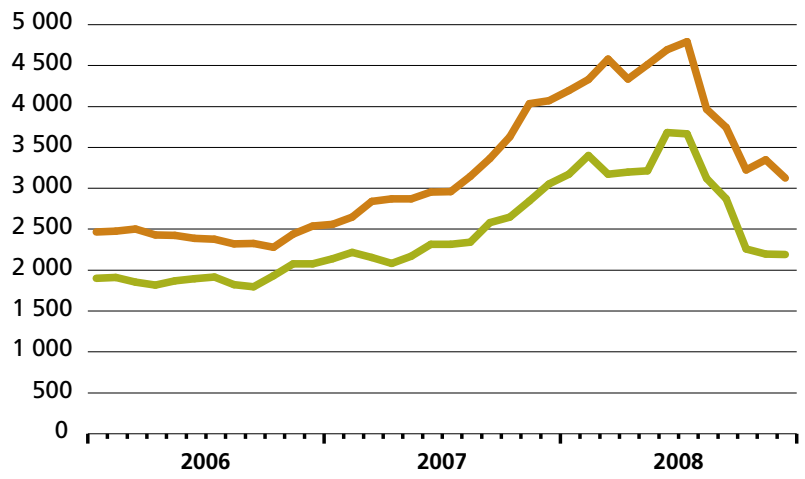

Domestic prices World prices

Source: C. Fang. 2010. How China stabilized grain prices during the global price crisis In D. Dawe, ed. The rice crisis: markets, policies and food security. London, Earthscan In D. Dawe, ed.
and Rome, FAO. further uncertainty for private traders. The resultant delays made it difficult to book transport at a reasonable cost, because most available trucks in the region had already been booked for other purposes. Finally, the tender for imports was not finalized for several months after the government had announced how much maize it would import. This created uncertainty as to when the government imports would arrive on the market. ${ }^{45}$ All of these factors created a very uncertain environment for private-sector importers, who as a result imported much less than they otherwise might have. The net result was a severe price spike on domestic markets in late 2005 and early 2006 (a 68 percent increase in nine months), even though international prices were stable (Figure 9). It would have been even worse had the Zambian kwacha not appreciated substantially at this time. There are many other similar examples. ${ }^{46}$

Even when controls on trade volumes do serve to stabilize domestic prices, there are costs to such policies. In terms of losses to the domestic economy, there are short-run economic efficiency losses from not allowing domestic prices to follow world price movements. In the short term, supply response is impeded and there are losses in export revenue (however, if farmers are also protected from price declines, trade controls might augment supply response at other times). In addition to the losses imposed on the domestic economy, export restrictions also result in world prices being higher and more volatile than they would otherwise have been, imposing costs on other countries.

The other main tool of trade policy, import tariffs or export taxes, in many cases will not impede transmission of

\section{FIGURE 9}

Market uncertainty caused by government interventions in the domestic maize market caused the price of maize in Zambia to spike in 2005-06, even though international market prices were stable

Inflation-adjusted price (2005 Zambian kwacha/kg)
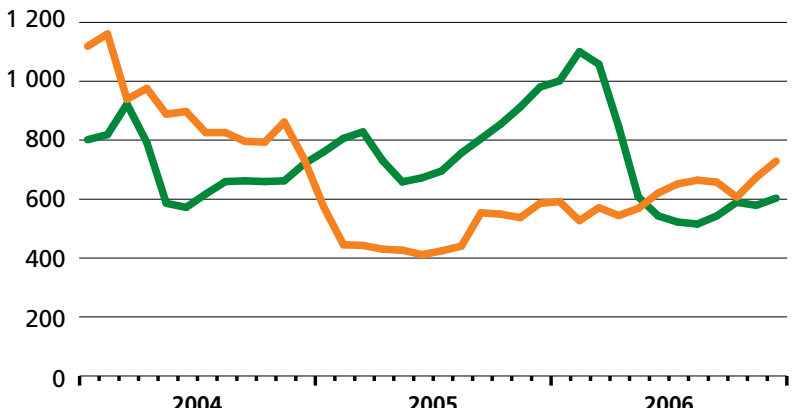

2005

2006

$$
\text { South Africa Zambia }
$$

Note: Prices for white maize from South Africa are used as a proxy for the world price because South Africa is the major source of white maize for the region. Sources of raw data: FAO Global Information and Early Warning System and International Monetary Fund 
Do export restrictions reduce or stabilize domestic prices?

In many cases, export taxes and restrictions do seem to stabilize domestic prices. This is especially likely when the restrictions have been in place for a long period of time, so that enforcement mechanisms are developed. Argentina, for example, has used export taxes on wheat for many years and did not experience the same spikes in domestic prices as were observed on world markets in 2007 and 2010 (see figure). An export tax would not stabilize prices, however, unless it increased as world prices increased, or

Export controls protected domestic prices for wheat in Argentina from the spikes seen on the world market in 2007 and 2010

Inflation-adjusted price (2005 Argentine pesos/tonne)

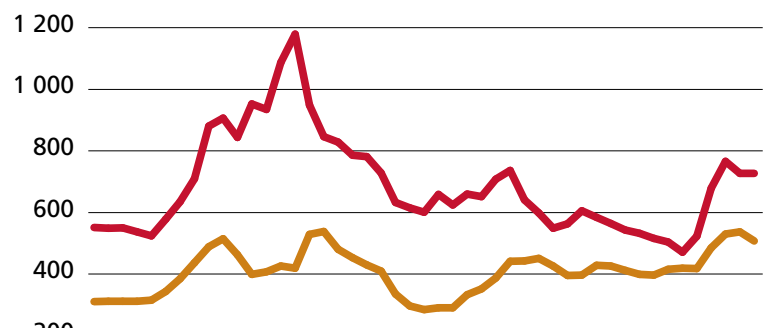

200

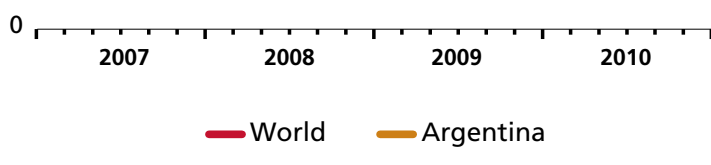

Notes: World prices are for United States hard red winter wheat, ordinary protein,

free-on-board, United States Gulf. Domestic prices are for wholesale hard wheat, Cordoba. Sources of raw data: FAO Global Information and Early Warning System, International Grain Council, International Monetary Fund. were so high that it eliminated all exports. Thus, in addition to export taxes, Argentina also used quantitative controls on wheat trade during 2007, ${ }^{1}$ which reduced the magnitude of the spike on domestic markets.

As is evident from the figure, however, the increased stability came at the cost of consistently lower prices for farmers, which reduced production incentives.

Furthermore, while prices were stabilized for farmers, the controls were much less effective in stabilizing prices for consumers. Wheat accounts for only about 10 percent of the cost of bread, which means that even giving wheat free to millers and bakers would reduce the cost of

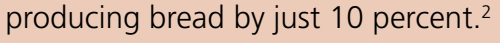

Not all countries with export controls are able to successfully stabilize domestic prices, however. Viet Nam, for example, restricted rice exports in the early months of 2008. Even though domestic supplies were more than enough to feed the population, domestic retail prices soared by 50 percent in only five weeks in April/May 2008. Government policies such as export taxes also changed frequently, adding to uncertainty and risk for traders later in the year after prices had declined on world markets. Indeed, domestic prices increased by 20 percent in just two weeks in the second half of August 2008, despite there being little movement on world markets at that time. ${ }^{3}$

$1 \mathrm{~J}$. Nogues. 2011. Agricultural export barriers and domestic prices: Argentina during the last decade. Report prepared for FAO 2 Ibid.

${ }^{3}$ P. Hoang Ngan. 2010. The Vietnamese rice industry during the global food crisis. In D. Dawe, ed. The rice crisis: markets, policies and food security. London, Earthscan and Rome, FAO. world price shocks to domestic markets unless the tariff/tax is varied in response to changes in world prices. A constant import tariff will raise the domestic price of food (and an export tax will lower it), but if the private sector is allowed to choose the amount they import at a given tariff, changes in world prices will often be completely transmitted to domestic prices until world prices or the tariff get so high that there are no more imports.

While trade controls may impede price transmission from volatile international markets, there are also disadvantages to such policies. For example, controls can increase price volatility due to domestic supply shocks (see 'What is the impact of self-sufficiency on price volatility?'). Higher domestic prices, in most cases, also tend to increase the level of poverty (see 'Costs and benefits of high and low food prices', pp. 13-18).

\section{What is the impact of exchange rates on world prices and price transmission?}

Exchange rate movements have two distinct, important effects. First, changes in exchange rates cause changes in world prices denominated in US dollars. For example, a depreciation of the US dollar against other currencies means that the world price of a commodity denominated in US dollars declines in terms of those other currencies. The lower price in currencies other than US dollars increases demand and reduces supply from those countries, both of which contribute to an increase in the price denominated in US dollars.

Second, changes in exchange rates can offset changes in US dollar prices on world markets, helping to reduce transmission of price changes to domestic markets. This did not eliminate transmission of world price shocks to domestic prices during 


\section{FIGURE 10}

Appreciation of the CFA franc against the US dollar

between 2003 and 2010 meant that the increase

in world rice prices was less in CFA franc terms than

in US dollar terms

Nominal price index $(2003=100)$

600

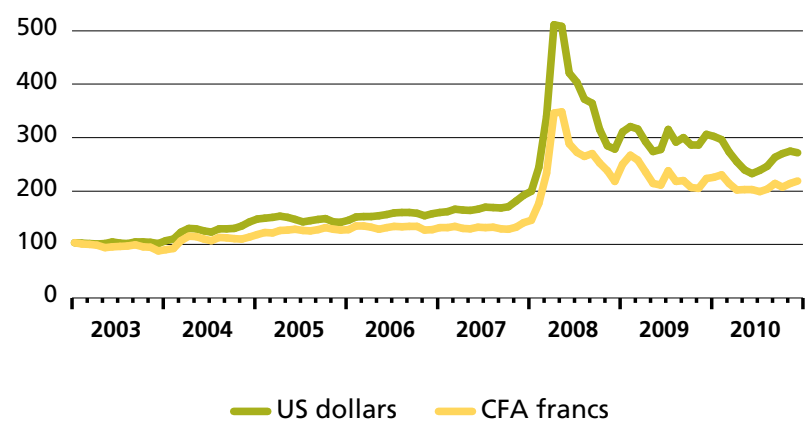

Note: Nominal prices are used instead of real prices in order to isolate the impact of exchange rate movements from the impact of deflating with two different price indices. Sources of raw data: FAO, International Monetary Fund.

the food crisis of 2006-08 simply because world price shocks were so large. Nevertheless, the impact of exchange rate changes should not be ignored. For example, between January 2003 and December 2010 the world price of rice increased by 169 percent in nominal US dollar terms but by just 116 percent in nominal CFA (Communauté Financière Africaine) franc terms. The difference was due to the appreciation of the euro, to which the CFA franc is linked, vis-à-vis the US dollar. ${ }^{47}$ Thus, even in the absence of any domestic commodity policies, much less of the world price increase was transmitted to western Africa than would have been expected given trends in the world price in US dollars (Figure 10). In some circumstances, the influence of exchange rates can be crucial: from January 2006 to November 2007, a span of nearly two years, world rice prices increased by 25 percent in nominal US dollar terms, but by just 3 percent in nominal CFA franc terms.

\section{What is the impact of self-sufficiency on price} volatility?

\section{Key message}

A food security strategy that relies on a combination of increased productivity and general openness to trade will be more effective than a strategy that relies primarily on the closure of borders.

At first glance, it might seem obvious that a country that is highly dependent on imports would be more likely to suffer large domestic price increases in the face of large world price increases than would a country that is self-sufficient or an exporter. In the absence of transport costs or government intervention, however, world price increases pass through to domestic prices directly for importers, exporters and selfsufficient countries alike. This is because private traders would be free to move supplies from domestic markets to world markets and vice versa until prices are equal across markets. Indeed, even exporting countries experience domestic price increases when world prices increase. For example, domestic prices for rice in Thailand increased sharply in 2008, because Thailand does not place quantitative restrictions on private-sector rice exports. ${ }^{48}$

Thus, being close to self-sufficient can reduce vulnerability to world price shocks, but only because it gives countries the option to place controls on international trade without suffering large domestic price increases. The closer a country is to self-sufficiency, the less its domestic prices are affected by world market prices, because under those conditions any increase in the world price is likely to make private imports unprofitable. This assumes that exports will not be allowed or will not be profitable (e.g. due to quality problems); if they are allowed or are profitable, world prices will be transmitted to domestic prices. For a country that is heavily dependent on imports, however, there is more potential for domestic prices to increase, because the high import dependence most likely indicates that the cost of domestic production is high.

On the other hand, it is important to realize that price volatility can originate from either international or domestic shocks. ${ }^{49}$ When a country is self-sufficient (because imports are not profitable due to trade barriers, tariffs or high transport costs), trade is not available to smooth domestic supply disturbances. This may exacerbate price volatility caused by fluctuations in agricultural output due to the vagaries of the weather. In such cases, domestic buffer stocks can serve as a substitute for international trade: stocks can be released when domestic production is low, and built up when there is a bumper crop.

Some countries have used buffer stocks effectively to stabilize domestic prices, but many countries have not. In addition, the costs to holding these stocks can be substantial. For example, in the case of Bangladesh, it would be cheaper in most cases to use imports to reduce price volatility than it would to store rice. ${ }^{50}$ Money invested in holding stocks has an opportunity cost in terms of key investments in agricultural research, rural roads and other public goods that are essential for a healthy agriculture sector and long-term economic growth (see 'Costs and benefits of volatile and unpredictable prices', pp. 18-20). Indeed, many governments realize the expenses involved and tend to reduce stock levels if prices are relatively stable for several years. Thus, trade should remain an integral component of a sensible food-security strategy.

It is also important to distinguish between self-sufficiency achieved through trade restrictions and that achieved through a competitive agriculture sector. Import restrictions 
can allow a country to achieve self-sufficiency, but it is much harder to move towards self-sufficiency through productive investment that makes the agriculture sector competitive on world markets. But the latter should be the real goal, because it is the only way to provide long-term benefits for both farmers and consumers.

Bangladesh is an example of a country that has made good progress in reducing undernourishment while maintaining general openness to trade and increasing productivity. The government allows private traders to import rice at a generally low tariff, and domestic rice prices have been roughly similar to those in neighbouring countries, including major exporters such as India and Thailand, for the past 20 years. At the same time, rice yields have grown rapidly over the past 20 years through investment in improved seeds and irrigation. Domestic prices for rice increased during 2007-08, but prices fell rapidly from the middle of 2008 because of a rapid increase in domestic production.

The experience of the Dominican Republic provides a different example. The government uses quotas, minimum support prices and other measures to influence domestic prices for rice and increase self-sufficiency. Domestic prices increased just 11 percent from 2007 to 2008 (in nominal US dollars) while prices in neighbouring countries increased by between 26 percent (Costa Rica) and 59 percent (El Salvador). But the smaller percentage increase in prices came at a cost, in the form of higher prices in more normal times before and after the crisis; quotas restrict imports, driving up domestic prices. Even during the crisis, prices for rice in the Dominican Republic were at similar levels to those in neighbouring countries (Figure 11). Thus, the policy of restricting imports has brought more stability, but at the cost

\section{FIGURE 11}

Government measures adopted by the Dominican Republic reduced the impact of the spike in rice prices in 2008 , but at the cost of higher prices before and after the crisis

\section{Domestic rice price (US\$/kg)}

1.40
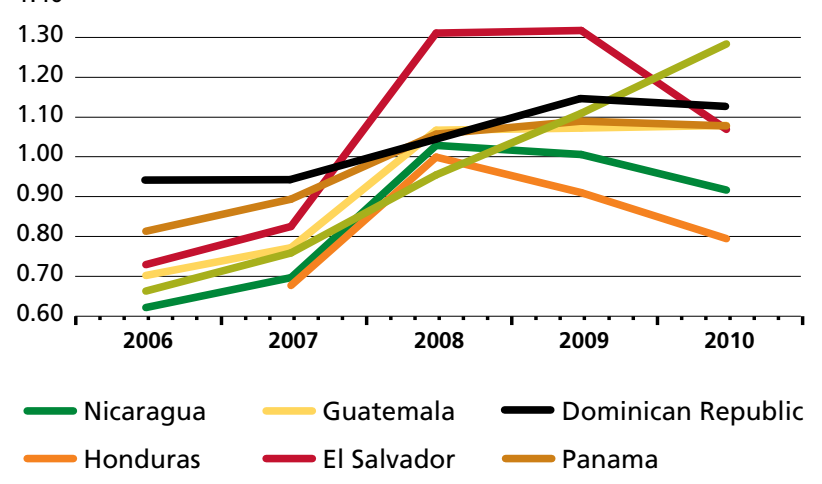

Costa Rica

Source of raw data: FAO Global Information and Early Warning System. of higher prices at almost all times. And as explained under 'Costs and benefits of high and low food prices', higher prices for staple foods increase poverty in most countries.

Furthermore, if a country has higher prices for staple foods than do its neighbours it may lose competitiveness in labourintensive industries, as it will be forced to raise wages to compensate for higher food prices. This might reduce employment opportunities, cutting off a pathway out of poverty through the non-farm sector. Thus, self-sufficiency that is due to trade restrictions instead of higher productivity has many negative side-effects. In sum, a food security strategy that relies on a combination of increased productivity and general openness to trade will be more effective in enhancing food security and reducing poverty than would a strategy that relies primarily on the closure of borders.

\section{Are traditional staples insulated from world price movements?}

\section{Key message}

Despite the price shocks on world markets, volatility of domestic prices for traditional staples such as sorghum, millet and cassava is greater than that for the traded cereals (rice, wheat and maize).

Some observers have noted that consumers in countries such as Ghana and Uganda who eat a wider variety of staple foods are less vulnerable to price surges on international markets than those who rely on major cereals. Thus, some have suggested that the poor and food-insecure should rely more on traditional starchy staples (such as cassava, millet and sorghum) for which international markets are much smaller and less well integrated with domestic markets and less on the major cereals. What do domestic price movements during the world food crisis tell us about these issues?

First, the prices of traditional staples typically increased during the world food crisis - they were not isolated from these events. This is exactly what would be expected if consumers were to increase demand for traditional staples in response to higher prices for the major cereals and producers were to increase supply of the major cereals at the expense of traditional staples. But even when the prices of traditional staples increased, the price increases were nearly always less than the increases in prices for major cereals, just as would be predicted by economic theory. Across a sample of 32 commodity pairs (one major cereal and one traditional staple in the same African country), between 2006 and 2008 the prices of major cereals increased by an average of 21 percent more than did the prices of traditional staples. Furthermore, the pattern also held for each of the 11 countries examined separately. Thus, the pattern of larger price increases for the major cereals than for the traditional staples was quite robust in Africa. 
But, as noted earlier, reduced reliance on international markets does not necessarily bring greater price stability. Indeed, a comparison of volatility of domestic prices across commodities for 20 African countries ${ }^{51}$ yields a striking conclusion: price volatility was least for rice or wheat in every one of the 20 countries between 2005 and 2010, despite the fact that this was a period of tremendous instability on world rice and wheat markets (Figure 12). Apparently, while rice and wheat prices experienced one large upward spike followed by a decline, domestic prices of traditional staples experienced several spikes and declines during the period. This is presumably because domestic supply shocks are a significant source of price variability, especially in Africa where much production is rainfed, not irrigated. Indeed, globally, 62,31 and 20 percent of the rice, wheat and maize areas is irrigated, compared with only 9,5 and 0.1 percent of the sorghum, millet and cassava areas. ${ }^{52}$ Further, much of the production of traditional staples is for home consumption, which means that the markets for these commodities are small, residual markets and are thus subject to greater price fluctuations. Finally, a lack of market information (relative to that available for the traded cereals) may mean that production of these traditional foods is more subject to cyclical patterns, where a high price encourages overproduction, which subsequently leads to low prices and underproduction, and so on.

Volatility of the price for maize was often less than that for the traditional staples, although this was not always the case. This is probably because domestic prices for maize are less well connected to international markets than is the case for rice and wheat, which are largely imported. The lack of connection is because most maize consumed in Africa is white maize, which is different from the yellow maize that is traded on world markets. This makes domestic prices more vulnerable to domestic supply shocks, as is the case for sorghum, millet and cassava.

To summarize, if international cereal prices surge, it makes sense for consumers to switch to traditional staples in order to reduce the impact on their household budget until prices of major cereals return to more normal levels. Thus, consuming a variety of staples provides a potential buffer against world price shocks. But it appears that the prices of traditional staples are more volatile than the prices of major cereals, not less.

Of course, the debate surrounding the relative advantages and disadvantages of imported cereals and traditional staples encompasses much more than just price volatility. For example, different crops will generate different levels of profits. In addition, if a farm household chooses to change the crops it grows this might change the intrahousehold allocation of labour, as well as income, as some crops are considered men's crops and others women's crops. Consumption decisions can also impact time allocation; greater reliance on foods that require more time for processing and cooking increases women's energy expenditures and reduces the time available for other productive activities, child care and needed rest. ${ }^{53}$ The nutritional content of different foods is also of key importance.

\section{FIGURE 12}

\section{Domestic price volatility (percent)}

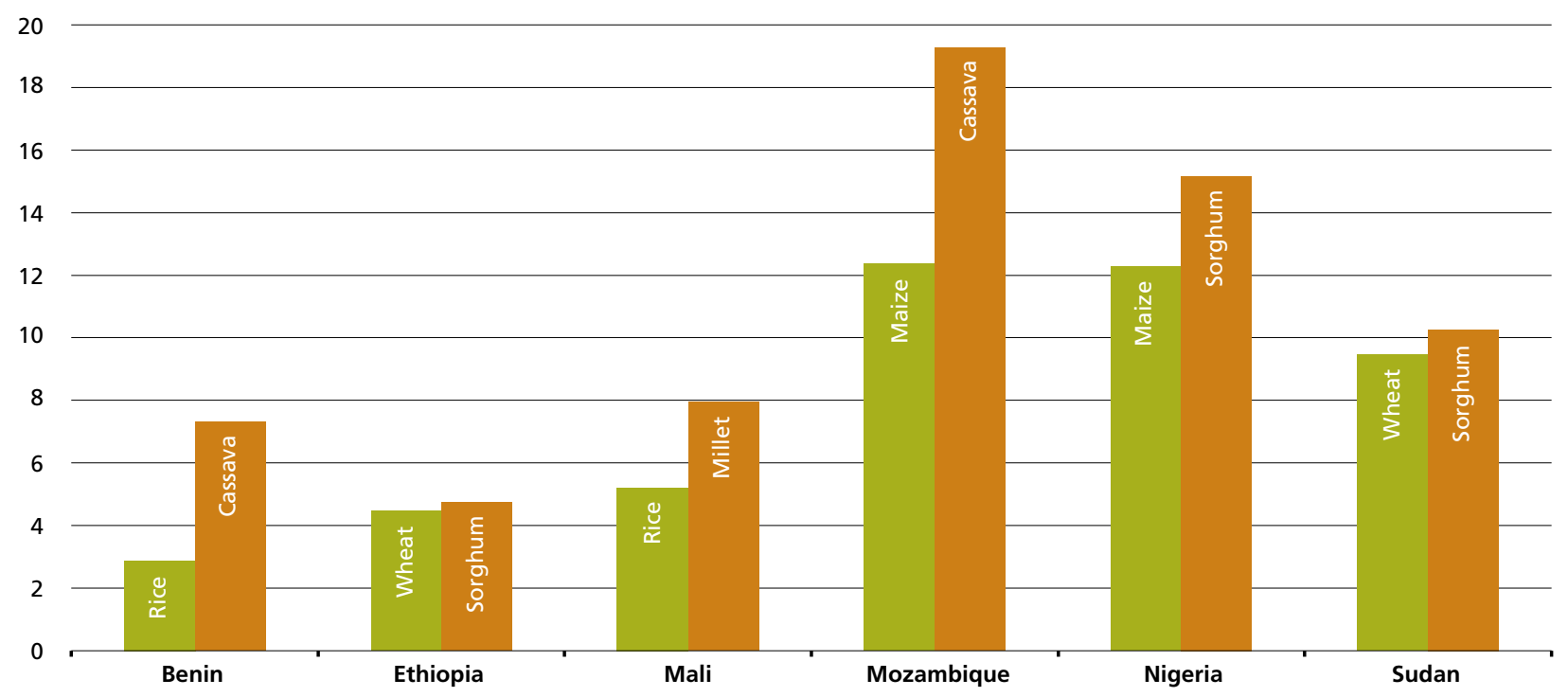

Note: Volatility was calculated as the standard deviation of monthly inflation-adjusted price changes.

Source of raw data: FAO Global Information and Early Warning System. 


\section{How did farmgate prices respond during the world food crisis?}

\section{Key message}

Evidence suggests that, in countries where retail prices increased during the world food crisis, farmgate prices also increased. But the volatility of prices during the crisis increased risks for farmers and will not promote longer-term investment by smallholders.

\section{FIGURE 13}

Farmgate prices for white maize closely followed retail prices in Burkina Faso from 2003 to 2010

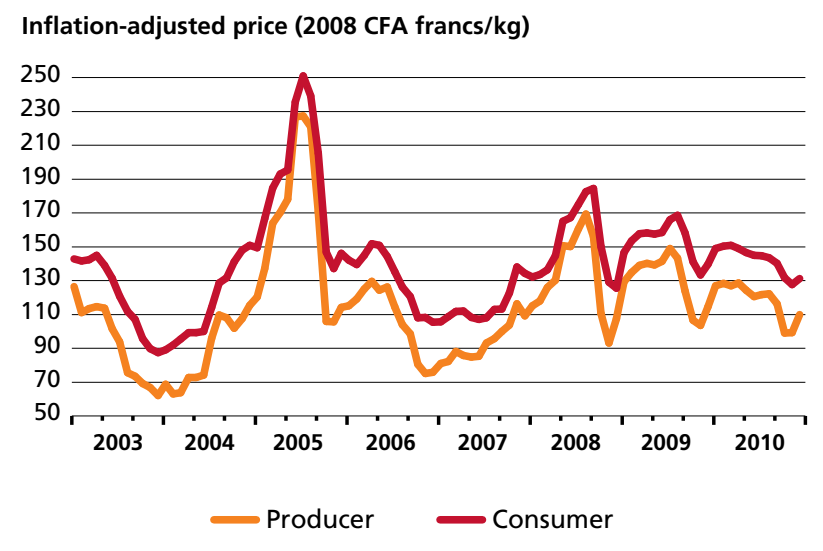

Sources of raw data: International Monetary Fund, Government of Burkina Faso.
The magnitude of supply responses in developing countries will be shaped by transmission of world prices not just to the retail level, but also to the farm level. If farmgate prices do not increase, there will be no supply response.

While there are many anecdotal stories of retail prices increasing while farmgate prices did not, hard data on farmgate prices are essential to address this issue in a convincing manner. While these data are not as readily available as data on consumer prices, there is some evidence to draw upon. The percentage increases in farmgate prices for rice, wheat and maize were very similar to those in consumer prices in several Asian countries (Bangladesh, China, Indonesia, Philippines, Thailand) between 2003 and 2008. ${ }^{54}$ In the United Republic of Tanzania, farmgate prices for maize followed a similar pattern to consumer prices from 2007 to 2008,55 and longer term data from Burkina Faso for both white and yellow maize also show similar movements at producer and consumer levels (Figure 13). Farmgate prices for maize in Kenya also increased substantially during the world food crisis. ${ }^{56}$ Based on this evidence (summarized in Figure 14), it appears that farmgate prices usually increase when consumer prices increase.

While general movements in farmgate and consumer prices over time are often similar, gross marketing margins (the difference between retail prices and farmgate prices) are not always constant. These margins have a seasonal pattern, with the margin being greater during the peak harvest because grain harvested at that time must be stored for a longer period of time before being sold than grain harvested in the off-season. In addition, margins are likely to increase at times when prices are less predictable, because less predictability means greater risk for traders. This happened

\section{FIGURE 14}

Farmgate prices generally increased as retail prices increased between 2003 and 2008

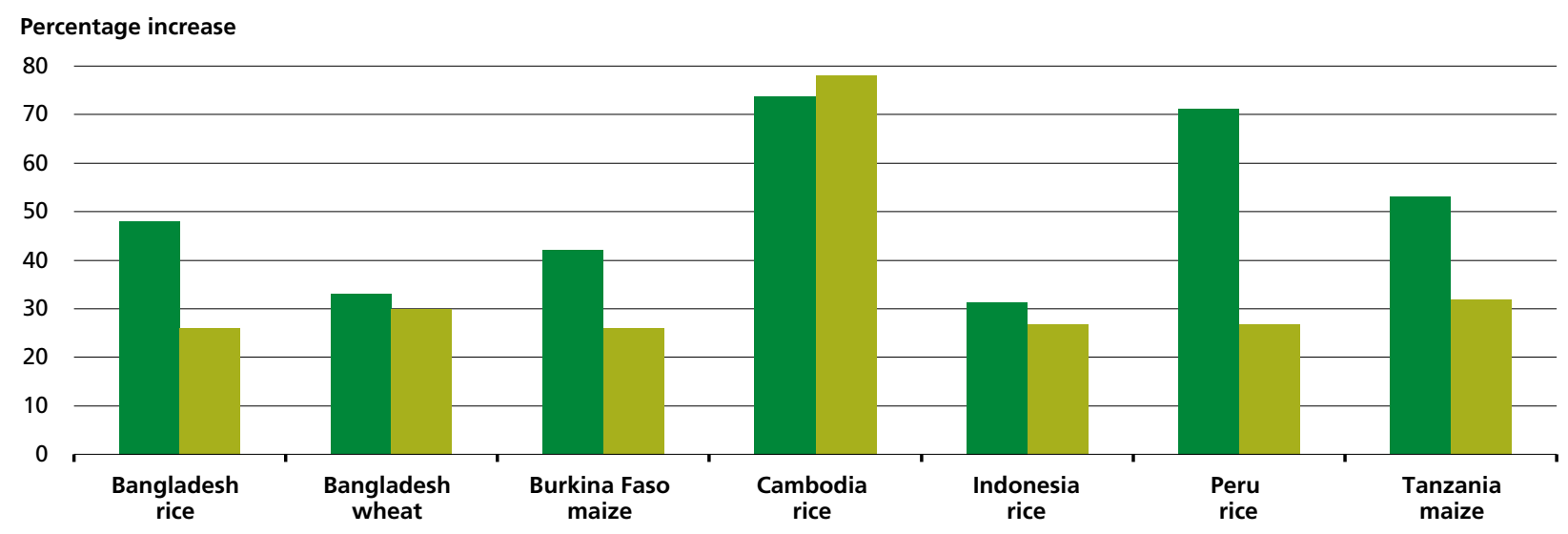


to rice marketing margins in both Thailand and the Philippines in 2008: farmgate prices increased substantially, but not by as much as wholesale and retail prices.

Indeed, many traders lost money during the world food crisis. ${ }^{57}$ Farmgate prices rose so fast that traders often could obtain supplies only at a price higher than the price at which they had agreed to sell to their clients. As a result they made losses, many substantial. It is also possible that traders had monopolistic power that they exploited to raise margins, although it would be difficult to say how much of any increase in margins was due to monopolistic behaviour and how much was compensation for higher risk. Finally, trading costs were also rising during the period of the world food crisis due to higher fuel costs.

\section{Do fertilizer price increases cancel out farm price increases?}

\section{Key message}

Increases in fertilizer prices harmed producers, but in many cases higher crop prices more than compensated for the extra costs incurred. This led to a large cereal supply response in many countries in 2008.
Between 2001 and 2008, world prices for nitrogen, phosphorus and potassium fertilizers all increased by more than world grain prices (Figure 15). The price of urea, a prime source of nitrogen and one of the most widely used fertilizers, more than quadrupled in real terms from 2001 to 2008. To the extent that these higher world prices were passed on to farmers, they reduced farm profitability and hence potential supply response. However, the extent to which fertilizer prices cancelled out farmgate price increases is probably less than commonly believed.

In traditional production systems that use little fertilizer, often the case for poor smallholder farmers, higher fertilizer prices have little impact on profitability. However, even in intensive production systems that use large quantities of fertilizer, the cost of fertilizer used is much less than the gross value of the crop produced, and it is the relative magnitude of these two quantities that determines the net impact of fertilizer price on profitability. For example, across a range of high-yielding Asian irrigated rice systems in six countries, the value of fertilizer applied was typically about 8 percent of the gross value of production in $1999 .{ }^{58}$ This implies that a doubling of fertilizer prices would raise production costs by 8 percent of the value of production (assuming no change in fertilizer use), which in turn means that an increase in output prices of just 8 percent would maintain profitability at a constant level. Even a further doubling (i.e. a four-fold increase in total, as happened on world urea

\section{FIGURE 15}

Between 2001 and 2008 world prices for nitrogen, phosphorus and potassium fertilizers increased by more than world prices for rice, wheat and maize

Index $(2001=\mathbf{1 0 0})$

600

500

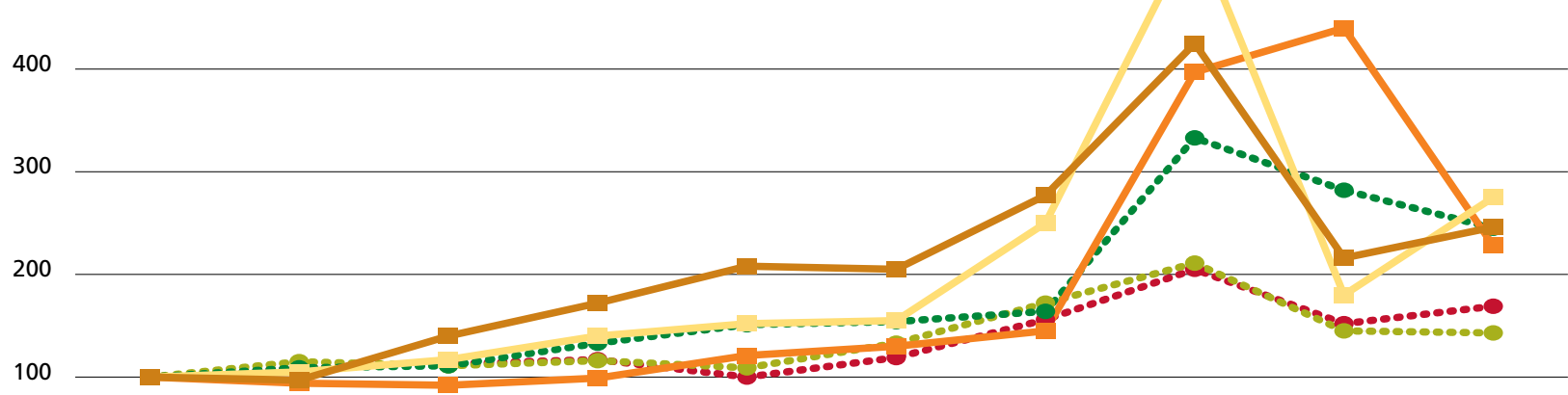

0

$\begin{array}{llllllllllll}2001 & 2002 & 2003 & 2004 & 2005 & 2006 & 2007 & 2008 & 2009 & 2010\end{array}$

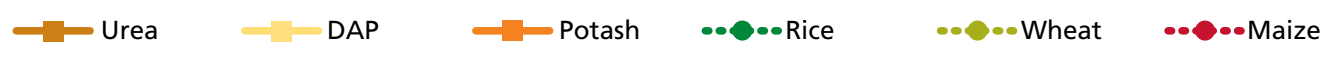


markets) would require just a 32 percent increase in output prices to fully compensate for the increased cost. Of course, if fertilizer prices increase substantially over the longer term and the cost of fertilizer became closer to the gross value of production, larger and larger increases in output prices would be required to compensate.

This general pattern is evident in Table 2, which shows the evolution of production costs and returns for winter-spring rice in An Giang province in the Mekong River Delta of Viet Nam. Between 2007 and 2008, fertilizer costs more than doubled, seed costs nearly doubled, labour costs increased substantially and yields fell, but a 57 percent increase in paddy prices was enough to lead to an increase in profits of 34 percent. Profits from rice production in
Bangladesh in 2007/08 more than doubled compared with the previous year. ${ }^{59}$ Not surprisingly, they subsequently fell in each of the next two years, although even in 2009/10 they were comparable to those in 2005/06. In Kenya, the combination of an increase of about 160 percent in fertilizer prices coupled with a 77 percent increase in maize prices from 2007 to 2008 led to more than a doubling of profits. ${ }^{60}$ However, the increase in profits is dependent upon maintaining fertilizer use - if fertilizer use falls because farmers cannot afford it, yields fall and profits may well decline. This scenario would not occur if credit markets functioned well, but in many cases they do not.

Figure 16 shows the percentage increase in crop prices required to compensate fully for a doubling of fertilizer and

\section{TABLE 2}

Profitability of winter-spring paddy in An Giang province, Viet Nam, increased in 2007/08 despite large increases in fertilizer and seed prices

\begin{tabular}{|c|c|c|c|}
\hline Item & 2007 & 2008 & Percentage change \\
\hline Seed & 484 & 936 & 93 \\
\hline Fertilizer & 3269 & 6691 & 105 \\
\hline Labour & 3116 & 4765 & 53 \\
\hline Other costs & 2928 & 2941 & 0 \\
\hline Yield (kg/ha) & 6100 & 5792 & -5 \\
\hline Paddy price (VND/kg) & 2350 & 3700 & 57 \\
\hline Profit & 4538 & 6097 & 34 \\
\hline
\end{tabular}

Source: Adapted from P. Hoang Ngan. 2010. The Vietnamese rice industry during the global food crisis. In D. Dawe, ed. The rice crisis: markets, policies and food security. London, Earthscan and Rome, FAO.

Notes: VND = Vietnamese dong. Costs and profits shown in thousands of Vietnamese dong per hectare.

\section{FIGURE 16}

Relatively small increases in crop prices can compensate for a doubling of fertilizer and fuel prices

\section{Crop price increase (percent)}

25

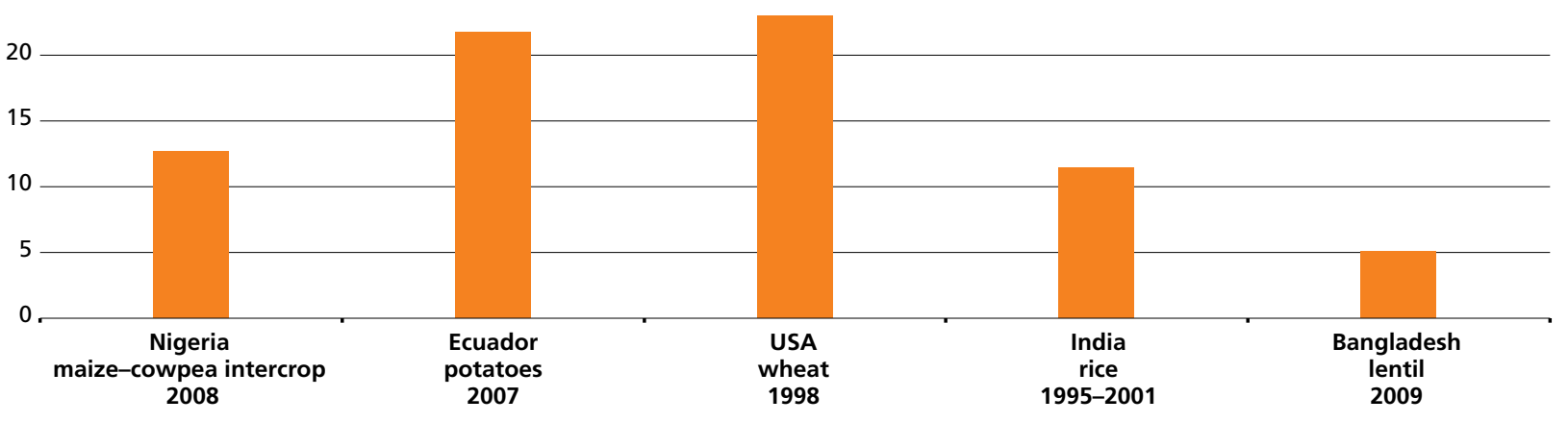

Note: Figure shows percentage increase in crop price that would be required to maintain profits if fertilizer and fuel costs doubled. The calculations assume that seed costs increase by the same percentage as crop prices, because seed prices typically increase along with output prices and constitute an additional burden for farmers.

Sources of raw data: M. Ali and G. Vocke. 2002. How wheat production costs vary. In: Wheat Yearbook 2002. Washington, DC, United States Department of Agriculture; A.O. Segun-Olasanmi and A.S. Bamire. 2010. Analysis of costs and returns to maize-cowpea intercrop production in Oyo state, Nigeria. Paper presented at the Joint Third African Association of Agricultural Economists (AAAE) and 48th Agricultural Economists Association of South Africa (AEASA) Conference, Cape Town, South Africa, September 19-23, 2010; R. Cavatassi, M. González-Flores, P. Winters, J. Andrade-Piedra, P. Espinosa and G. Thiele. 2011. Linking smallholders to the new agricultural economy: the case of the Plataformas de Concertación in Ecuador. Journal of Development Studies (forthcoming); M.A. Rashid, M.K. Hassan and A.K.M. Harun-ur-Rashid. 2009. Domestic and international competitiveness of production of selected crops in Bangladesh. Final Report CF No. 1/08. Dhaka, National Food Policy Capacity Strengthening Programme; B. Vinayakumar, N. Kollurmath, N. Karnool, L.B. Kunnal, H. Basavaraj and V. Kulkarni. 2008. Cost of production of rice and maize in World Trade Organization era of Karnataka. Karnataka Journal of Agricultural Science, 21(2): 241-245. 
fuel prices in a variety of production systems around the world. (Costs of fuel and fertilizer commonly rise in tandem because natural gas is a major input in the production of urea fertilizer.) Highly mechanized systems, or those that rely on pumping of groundwater, would be affected more because of the importance of fuel costs. The effects would be less in no-till systems that use surface irrigation water or that are rainfed. Thus, the impact of changes in fertilizer and fuel prices would vary across different types of production system, but in many cases it would take only a small increase in output prices to compensate for even a large increase in fertilizer prices. In other words, an increase in the ratio of fertilizer price to output price does not necessarily imply a decline in profitability. Indeed, during the world food crisis, it appears that supply response was quite substantial in a number of developing countries. ${ }^{61}$ Farmers in developing countries do respond to higher prices, in terms of increases in both area planted and yield, ${ }^{62}$ although the response is reduced when prices are unstable. ${ }^{63}$

Timing of price changes can also be important. In Viet Nam in 2008, farmers planted the summer-autumn rice crop when both rice and fertilizer prices were relatively high. The high rice price contributed to an increase in area planted, but by harvest time rice and fertilizer prices had fallen sharply (in line with world prices). Unfortunately, the farmers had to sell their output at the new lower price, but did not benefit from the lower fertilizer prices (at least not for that crop) because they had bought and applied fertilizer before the prices dropped. On the other hand, the winterspring crop harvested earlier in 2008 benefited from a substantial, unanticipated increase in rice prices, which led to a sharp increase in profits (Table 2). Thus, timing issues can cut both ways.

To summarize, farmgate prices and profits appeared to increase in many cases during the world food crisis but the increase was only temporary. The increase in volatility (see Figure 6, p. 22), coupled with the fact that by the second quarter of 2010 domestic prices in real terms had largely returned to pre-crisis levels (Figure 5, p. 21), means that the incentives for smallholder farmers to increase long-term farm-level investment (as opposed to short-term supply response) have been weak. 


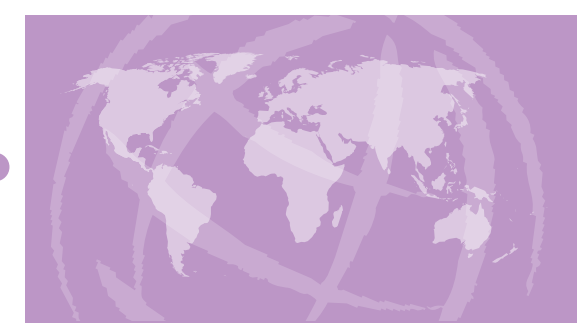

\section{Policy options to address price volatility and high prices}

B efore considering interventions to reduce and manage domestic price volatility, it must be recognized that some price volatility is an inherent characteristic of agricultural commodity markets. In the short term, because there is a mismatch between timing of supply (which is seasonal) and timing of demand (which is much less seasonal), agricultural commodities must be stored, and storage will not be profitable unless prices vary during the course of the year. Over the longer term, if the increase in food production is not keeping pace with demand growth, it is important that prices increase. This will provide incentives for farmers to increase supply and for the private sector to increase research and development, and will provide signals for the public sector to increase spending on public goods that support agricultural production and markets.
Broadly speaking, interventions to reduce the costs associated with price volatility can be divided into two types. First, there are interventions that reduce price volatility, such as improving market information (Box 7). Second, there are interventions that accept price volatility as given and attempt to cope with it. These coping mechanisms can be either before (ex ante) or after (ex post) the fact. Further, the interventions can occur at either the international or the domestic level, and can be implemented by either the public or the private sector. Some interventions fit into more than one of these categories. Use of domestic buffer stocks and trade controls, for example, accept international price volatility as given and try to cope with it after the fact. But, at the domestic level, these interventions also try to reduce domestic price volatility.

\section{BOX 7}

\section{Improving market information systems to reduce price volatility}

Information on the current situation and outlook for global agriculture shapes expectations about future prices and allows markets to function more efficiently. Conversely, lack of accurate information on market fundamentals may reduce efficiency and accentuate price movements. Better information and analysis of global and local markets and improved transparency could reduce the incidence and magnitude of panic-driven price surges.

Recent events have revealed weaknesses in the capacity of nations and international organizations to produce consistent, accurate and timely agricultural market data and analysis, especially in response to weather shocks such as floods or droughts. Action is needed to increase capacity to undertake more frequent and systematic monitoring of the state of crops and to develop mechanisms for improved short-run production forecasts that are able to translate crop growth, meteorological and remote sensing data into yield and production expectations. Greater use could be made of satellite data and geographic information systems and, in this context, international coordination and exchange of technologies and information could be enhanced.

Information on food stocks is an essential component of a global food market information system, yet reliable data on stocks of grains and oilseeds are often not collected or, if collected, are not reported publicly. The reasons for the lack of good stock data are multiple: some countries no longer hold public stocks because the policy measures that created them have been removed or reformed; stocks can be very dispersed among farmers, 
traders and other actors and hence difficult to track; and some information on stocks is commercially or politically sensitive. Generally, international agencies estimate net changes in stocks from data on production, consumption and trade. As a result, it is not possible to have complete confidence in world food stock estimates. International cooperation could redress this situation and ensure that reliable information on global stocks becomes widely available. This would, in turn, better inform market participants and help avoid panic-induced price surges resulting from misinformation.

Monitoring food prices, on both cash and futures markets, is another essential component of a food market monitoring system. Assessing changes in oil prices and analysing their impact on food markets is also important. Better information about domestic price movements is necessary to understand how international price changes affect domestic markets in developing countries. Such information is important for early warning systems, such as the FAO Global Information and Early Warning System and WFP's Vulnerability Analysis and Mapping Unit. It is also crucial for policy-making and designing effective risk management instruments for developing countries.

For developing countries, enhanced market information and early warning systems would enable both governments and the private sector to plan ahead. Governments would be able to assess needs more accurately, make budgetary provision for producer and consumer safety nets and better position emergency food-security reserves. Improved market information and analysis could reduce uncertainties and help producers, traders and consumers to make better decisions.

Over the last decade a great deal of baseline information on food security vulnerability has been developed. WFP support to national food-security monitoring systems already provides a monitoring and decision-support tool to help governments manage and respond to risk related to price, weather or other hazards. At a regional level, a few successful efforts, such as the Famine Early Warning System Network, have increased the availability of information to governments and market participants. The reliability and timeliness of such early warning systems need to be improved, and capacity to develop and utilize them should be strengthened at both the national and the regional levels. The focus should be on countries that are particularly vulnerable to price shocks and food emergencies.

The experience of the 2006-08 food price crisis and the current high price volatility in many international food markets have exposed weaknesses in relation not only to the provision of market information at the global level but also to the coordination of policy responses to food price volatility. There is a need to ensure better preparedness and more rapid and consistent policy responses in times of crisis. Building on and complementing existing systems, improvements in global market information and policy guidance could be achieved through a collaborative food information and policy initiative currently being discussed by a number of international organizations: the Agricultural Market Information System (AMIS). Such an initiative would improve data reliability, timeliness and frequency, as well as enhance policy coordination in times of crisis.

AMIS could be built on the model of the Joint Oil Data Initiative, launched in 2000 to improve information about oil markets. However, it would have the additional functions of issuing global food price surge alerts and promoting policy coherence. AMIS would involve the major food producing, exporting and importing countries. It would also involve a secretariat composed of international organizations with the capacity to collect, analyse and disseminate information on a regular basis regarding the food situation and outlook as well as to develop food policies.
There are some basic principles that should be considered when designing interventions. First, although it is difficult to quantify the costs and benefits of various policies, it is important that interventions be designed with costeffectiveness in mind whenever possible. This is important to ensure that public funds are available for critical investments in agricultural research, roads, education and health.

Second, it must be recognized that the private sector will play a critical and dominant role in an efficient marketing system, defined as one that provides higher prices for farmers and lower prices for consumers. There are no examples of efficient marketing systems for food commodities that are dominated by the public sector.

Third, while government intervention into food markets will likely continue into the future, these interventions should become more predictable and take into account their impact on the behaviour of the private sector. Erratic government interventions not only raise costs for the private sector, impeding its development, but also often increase price volatility. There are several examples of government interventions that have discouraged the private sector from arranging imports and resulted in a surge in domestic prices. ${ }^{64}$

Fourth, aside from the general principles listed above, it must be recognized that each country is unique in many respects. In order to take account of different situations, each country should analyse its own circumstances and engage in policies appropriate to those circumstances. Country-specific experimentation along these lines should be encouraged. 


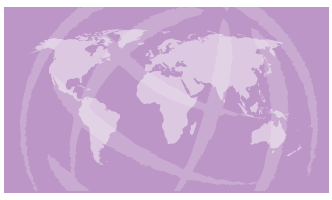

\section{Preventing domestic price volatility in the short term: trade policies and buffer stocks}

\section{Key message}

Government policies that are more predictable and that promote participation by the private sector in trade will generally decrease price volatility. More predictability for private traders will decrease risk, leading to narrower margins, lower prices for consumers and higher prices for farmers.

Reducing domestic price volatility has historically been a concern for many countries, both developed and developing. In order to achieve their objectives, developing countries have typically used a combination of trade controls and buffer stocks.

As noted earlier, price volatility may originate from either domestic or international markets. Thus, a comprehensive policy on volatility cannot focus on international price shocks to the exclusion of domestic supply disruptions. In general, trade is the most cost-effective way to stabilize domestic prices in the face of shocks to domestic supply. For trade to be most effective, however, a solid market information system is of prime importance, so that imports can be arranged (whether by the government or the private sector) in a timely fashion. If there will be significant lags in the arrival of imports or access to emergency humanitarian reserves, buffer stocks may have a role to play.

In the case of shocks emanating from world markets, countries have two basic choices (or combinations thereof):

- Accept the price volatility and cope with it through a combination of risk management instruments and safety nets.

- Use a combination of trade controls and buffer stocks to reduce price transmission from international markets.

Both of these options have costs. The costs of price volatility were described earlier in 'Costs and benefits of volatile and unpredictable prices', and can be substantial. On the other hand, buffer stocks and trade controls also have costs. For example, the interest costs of buffer stocks can be significant. Furthermore, maintaining a buffer stock at a given level may involve trading twice that volume annually in order to maintain stock quality. These trades represent significant transaction costs (or quality deterioration if the trades are not carried out). Government interventions to stabilize domestic prices increase world price volatility and hurt poorer and smaller countries that are heavily reliant on food imports. If trade controls reduce domestic prices, supply response will be lower than it otherwise would have been. This can create serious problems if the controls are sustained over time, because most observers expect higher world food prices in the future, in which case the world will need additional supplies. ${ }^{65}$

On balance, it is not easy to quantify whether the costs of price volatility are greater or less than the costs of interventions to prevent it, and the answer will surely be situation-specific. It is possible, however, to offer some guidelines, informed by both historical experience and theory, that would help to lower the costs of government interventions.

Some rice-producing Asian countries have relied on a combination of international trade, buffer stocks, import or export monopolies and domestic procurement to stabilize prices. These measures were often successful in achieving their objectives and, in some cases, may have stimulated economic growth as well (see Box 8). In Africa, the experience with stabilization of the maize market has been less successful, as interventions have often been unpredictable and less supportive of a strong role for the private sector in marketing activities. Private traders have had to deal with uncertainties surrounding many important factors, including:

- the issuance of import and export licences;

- the level of the tariff, and which groups of private traders might be exempt from it;

- the level of government imports and the price at which they will be sold;

- the enforcement of sanitary and phytosanitary regulations; and

- transport across national borders.

Taken together, these uncertainties raise market risk significantly, discourage the private investment that is essential for a well-functioning market and leave many economies unnecessarily prone to food shortages.

Government policies must be relatively transparent and predictable if the private sector is to play its roles in moving supplies from surplus to deficit areas and in storing supplies between harvest and the lean season. Furthermore, they should also try to minimize costs as much as possible in order to make sure that agricultural budgets are used primarily for investments in research and other public goods that can provide long-term solutions to price volatility.

Many government policies on food trade seem to stem from a distrust of private traders. One key step that could be taken in many countries is the establishment of regular, 


\section{Rice price stabilization in Indonesia}

Indonesia successfully stabilized domestic rice prices for more than a quarter of a century from 1969 to 1996 (see graph below). During that period, domestic prices were roughly equal to world prices on average, but were substantially less volatile. Stabilization was achieved through a combination of international trade (usually imports, but occasionally exports) and buffer stocks that were procured and distributed depending on whether production was in surplus or deficit. ${ }^{1}$ Although the amount of rice that the government bought varied from year to year with the size of the harvest, it was on average less than 5 percent of domestic production. In other words, the private sector was responsible for marketing 95 percent of the rice crop. Furthermore, nearly all of the government procurement was done through traders, not directly from farmers.
A floor price was announced every year before the main crop was planted, thus providing clear incentives to farmers to adopt new technologies. The level of the floor price that was announced took into account current inflation rates and was adjusted up or down slightly depending on world price movements, fertilizer prices and other factors. The level of the floor price, after adjusting for inflation, was relatively stable over time, providing stable long-term incentives for investment in rice production. The overall benefits of the rice price stabilization programme were substantial, although the benefits fell over time as the importance of rice to the economy declined with economic growth. ${ }^{2}$

${ }^{1}$ C.P. Timmer.1996. Does BULOG stabilize rice prices in Indonesia? Should it try? Bulletin of Indonesian Economic Studies, 32: 45-74. ${ }^{2}$ C.P. Timmer. 2002. Agriculture and economic growth. In B. Gardner and G.Rausser, eds. Handbook of agricultural economics. Vol. IIA pp. 1487-1546. Amsterdam, North-Holland.

\section{Indonesia managed to stabilize its domestic price for rice from 1969 to 1996 through trade and buffer stocks}

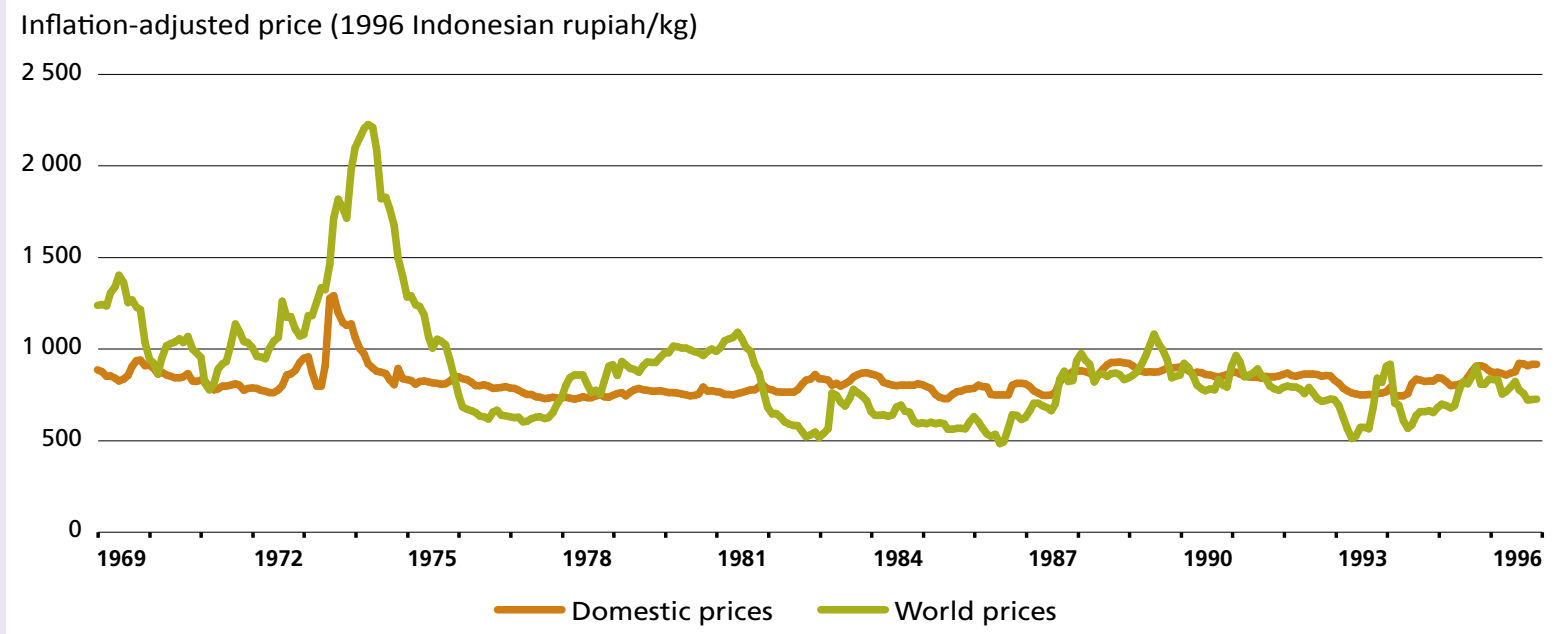

Sources of raw data: Indonesian Bureau of Logistics (BULOG); International Monetary Fund.

formal, open lines of communication between the government and the private sector. These could increase transparency and might help to avoid crises by providing advanced warning of impending problems that might harm the food security of the poor. ${ }^{66}$

International trade has a key role to play in reducing domestic price volatility, but the fact that World Trade Organization rules on export barriers are much weaker than those on import barriers is a severe obstacle to increasing trust in international markets. Indeed, export restrictions have exacerbated price volatility on international markets in recent years (see Box 9). Net food importers need much stronger guarantees from their trading partners if they are to rely on international trade as a source of food. A 'first best option' would be a ban on export restrictions, with countries addressing domestic food security issues through direct and targeted support. However, it is unlikely that a ban on export restrictions would be agreed or, even if agreed, would be enforced during a food crisis. On the other hand, reinforced rules, in particular in terms of transparency, are both possible and useful. 
The world rice crisis

Price volatility on international markets can sometimes be caused by domestic market intervention policies - the world rice crisis of 2007/08 provides a good case study in this regard.

The rice crisis was not caused by any problems in the basic balance between production and consumption. First, rice production kept pace with increases in demand in the years before the crisis, and there were no major supply shocks in 2007/08. Indeed, global rice production reached new record highs for four straight years starting in 2005. Second, reflecting the good production outcomes, the stock-to-use ratio remained roughly constant in the three years before the crisis - there was no drawdown that would have made the market vulnerable to small disruptions in production. Third, despite some concerns that exporters did not want to sell (perhaps in anticipation that prices would continue to rise), there were supplies available on international markets for importers - the volume of exports in the first four months of 2008 was about 20 percent higher than in the same period in 2007.

While fundamentals in the rice market were sound, those for other food commodities did point to higher prices. Increased demand for biofuel from maize and oilseeds, and a nearly 4 percent decline in global wheat production in 2006/07 (including a severe drought in Australia, a leading wheat exporter), led to higher prices in those markets. Higher prices for maize and wheat probably led some consumers to shift from wheat to rice, which would have placed some upward pressure on rice prices. However, the size of the rice price increase went well beyond what could be explained on the basis of such substitution - it was ultimately government policies that led to the crisis. Indeed, the price hike was faster and stronger for rice than for cereals with less favourable market conditions.

In addition to higher maize and wheat prices, rising oil prices and a weak US dollar also contributed to higher commodity prices in general. These factors created concern in some countries that rice prices might increase as well. Indeed, rice prices had been rising since 2003, but the price increase during that time was relatively slow and steady (and thus easy to manage). Beginning in October 2007, however, government policies in a number of countries caused prices to increase rapidly. Large producers of rice restricted supplies to the world market in order to avoid shortages for their own consumers, either completely banning exports or announcing increasingly high minimum export prices. Governments of rice-importing countries scrambled for supplies to stabilize their own markets, often buying very large quantities and paying above market prices. Others announced plans to build up stocks during the crisis, further driving up demand. As a result of these policies, prices on world markets tripled between October 2007 and April 2008. Even during the world food crisis of 1973-75, world rice prices had never doubled within six months, much less tripled.

While trade restrictions allowed some countries to prevent transmission of the price surge on world markets to their domestic prices, domestic stability was achieved at the cost of destabilizing the world market. It is very likely that the rice crisis would not have occurred if these measures had not been taken. Thus, one lesson from the rice price crisis is that disciplines of the World Trade Organization need to be strengthened so that export restrictions are used less frequently. Enforcement of any such disciplines might, however, be difficult, as noted earlier.

Making trade restrictions less harmful offers an additional approach to stabilizing the world rice market. An important step in this direction would be to make government policies more predictable. While many governments understandably want to maintain some flexibility in response to sudden unforeseen events, some policy changes could be avoided. Others might be implemented according to pre-announced schedules or criteria that determine when changes are phased in automatically in response to external events; this would make price changes more predictable.

The rice price crisis also demonstrates the need to strengthen the role of the private sector in carrying out trade, even if governments determine when trade takes place. Private-sector traders are unlikely to pay abovemarket prices, and their smaller trade volumes are less likely to move the market. Expanding the role of the private sector is particularly important for the world rice market, which is smaller than other world cereal markets and can thus be influenced more easily by large operations of governments. 


\section{Coping with likely future price volatility:} risk management for smallholder farmers and governments

\section{Key message}

Agricultural research and cost-effective irrigation are urgently needed in order to reduce the production risk facing farmers, especially smallholders. These types of investments will reduce price volatility and will also lower production costs per tonne, which will reduce food prices.

Farmers face both production risks and price risks. A prudent risk-management strategy must consider both sources of risk, especially since one type of risk can offset the other in some circumstances (e.g. a domestic supply shock can lead to higher prices, so that reduced production is compensated for by higher prices).

Adverse weather and pests and diseases reduce farm income and result in more variable production. Climate change will likely increase these types of risk in the future. Many technologies, such as the introduction of disease- or stress-resistant varieties or the construction of irrigation and drainage systems, can reduce the risk to which farmers are exposed. For example, submergence-tolerant rice is spreading rapidly in parts of Asia where floods are frequent. Another promising way to reduce the risk facing farmers is through the use of improved small-scale storage technologies that smallholder farmers and consumers can afford. ${ }^{67}$ Such technologies would reduce post-harvest losses and also provide a buffer against price shocks that might reduce the potential for panic-driven surges in demand. Such technologies are the most important way to reduce the risk facing farmers and countries, and should be strongly supported by both national governments and donors.

Market-based insurance mechanisms provide another way to transfer risk and assist farmers in making production decisions. It must be recognized, however, that any commercially viable insurance when offered as a standalone product will lower the average level of farm income in the short term, as a private insurance company will not offer a product if it consistently pays out more than it receives. Over the longer term, however, the reduced risk faced by farmers can encourage them to invest in more-profitable technologies that raise their productivity and income. For example, insurance when bundled with credit, inputs, and other services can allow households to take prudent risks knowing they will be protected if there is a disaster. Governments can (and often do) provide subsidies for insurance, but these programmes have typically been very expensive to operate, even in developed countries. Subsidies to such programmes need to be balanced against the costs and benefits of expenditures on agricultural research and irrigation.

Considerable effort and research are being invested in developing ways to address the challenges of insuring smallholders against production risks. One such innovation is weather-index-based crop insurance. This pays out to farmers whenever particular weather factors - rainfall or temperature, for example - cross specific thresholds at which they are likely to cause a significant fall in crop yields. These factors are measured by weather stations or even satellite technology. The advantage of this approach is that insurers do not need to make field-level assessments, which reduces administrative costs. In addition, farmers who have such insurance do not have incentives to mismanage their crop (a problem known as moral hazard) in order to receive a payout, since the payout is based on an external measurement rather than crop yield.

However, weather-index-based insurance requires a number of conditions to be in place. First, the index chosen must be strongly correlated with local yields, or else farmers are not insuring themselves against the relevant risk (this is known as basis risk). Second, there must be adequate infrastructure, such as a network of local weather stations and/or available remote-sensing options, reliable historical data and an adequate legal and regulatory environment. Third, farmers should have a clear understanding of how such insurance works and should be able to pay for it. Finally, for index insurance to be effective, it should be linked to other financial services as part of a larger package of risk management solutions.

The use of futures markets by smallholders in developing countries to manage price risk seems more problematic at present. Few developing countries have commodity exchanges where farmers and other market participants can 
hedge against price fluctuations. Moreover, there are substantial fixed costs of participation in such markets in terms of knowledge and understanding, and it is less profitable for a farmer to acquire such knowledge if her or his farm is small. Even in the United States of America, only
3 percent of farms used futures contracts in $2008 .{ }^{68}$ In general, it has proved extremely difficult to reach smallholders in a cost-effective manner.

Governments face risks similar to those faced by farmers, and some of the available instruments are similar as well.

\section{BOX 10}

\section{What happens to the operations of the United Nations World Food Programme - the largest purchaser of food for humanitarian purposes - when food prices rise?}

Rising food prices affect the World Food Programme (WFP) in two ways: they make it more expensive to purchase food for the existing programmes to feed the hungry and they increase the number of people needing food assistance.

The WFP business model is unique in the United Nations System. It is funded entirely through voluntary donations and receives no assessed contributions, core funding or membership dues. As a result, and because of its constitution, it is unable to hedge prices of commodities in the market place in the way that a large private-sector company might do.

Two factors are key drivers of WFP costs. The first is the prices of food commodities themselves. WFP procures its food commodities on spot markets. Thus, when the food price crisis struck in 2007 WFP was fully exposed to the effect of the increases. Every 10 percent increase in the cost of the WFP food commodity basket adds around US $\$ 200$ million to the cost of feeding existing beneficiaries.

The second cost driver is transportation, which is linked to fuel prices. Given the need for food to be transported to some of the most remote areas of the world, including air drops of food in the most difficult terrains, fuel prices are significant determinants of WFP costs.

Between June 2007 and February 2008 the cost of meeting the needs of WFP's existing client load increased by US\$775 million.

The next dimension is securing resources for the needs of those who have become newly dependent on food assistance as a result of food price rises in their locality. Between June 2007 and February 2008 WFP needed US\$186 million extra to expand interventions through schools to about 4.8 million beneficiaries in 11 countries, to distribute specialized foods to about 1.8 million malnourished children and pregnant and lactating women, extend public works programmes to over 4 million beneficiaries so that they could put food on the table and to introduce cash transfer and voucher programmes to about 800000 people in seven countries to enable them to access available food in the marketplace.

Resource savings were achieved by changing commodities in some food baskets, for example by substituting sorghum for maize in parts of Africa. Even so, the overall additional costs for WFP in 2008 were US $\$ 920$ million.

The final challenge that arose for WFP in 2007 and 2008 was the actual procurement of food. As food commodity markets tightened, WFP faced difficulties in actually securing food and getting it to the right place at the right time. On average, it takes 3-4 months between securing food commodities and delivering them to where they are needed. WFP procures food competitively and as close as possible to the place where it is needed, taking into account both the commodity cost and the transportation cost. In 2010 WFP bought 78 percent of the food it needed in developing countries. However, the challenge it faced was exacerbated by more than 30 nations imposing food export bans in an effort to protect their own consumers. While humanitarian exports are usually exempt from such bans, the process of negotiating with each government when WFP encountered the ban took valuable time.

\section{How is WFP responding?}

Prior to the food price crisis WFP was unable to procure food until it actually received a financial contribution from a donor. Following the 2008 food price crisis, WFP's Executive Board moved quickly to provide authority to pre-purchase and pre-position food for vulnerable populations once a financial commitment was made. A US\$60 million forward purchase facility was put in place to buy commodities and pay shipping costs prior to receipt of donor contributions.

WFP is now planning to expand this system to increase the level of forward planning and purchasing it undertakes to include pre-positioning of stocks for quick delivery to vulnerable people affected by food crises, supported by an expanded revolving financing facility of US\$150 million. Stocks will be located along up to eight major humanitarian corridors. This facility does not enable WFP to hedge either commodity price or exchange rate risk, but does allow it to shorten the time between food needs being identified, financial resources being obtained and food being delivered to those in need. 
For example, weather-index-based insurance was first used at the national level in Ethiopia in 2006 and in Malawi in 2008 to manage production risks; it is still in operation. Given the technical nature of such market-based approaches to managing food price volatility, there is a need to establish institutions at the national level and build up technical expertise within those institutions.

The principal instruments that could be used to manage the price volatility of food imports are futures and options contracts. By buying futures contracts, a government that wishes to protect itself against a possible surge in the price of grain locks in a price agreed at the time the contract was concluded. Futures contracts give the country greater certainty of the price it will pay for the grain, but do not offer flexibility. Should the market price move lower, the government will still have to pay the agreed price, and hence pay more than it otherwise might have had to. In poor countries this can create considerable political difficulty, in addition to the financial loss. In practice, futures may not be a useful instrument for governments since there is an unpredictable and potentially large liability associated with taking a futures position.

Call option contracts lock in a maximum price, but with no obligation to buy at that high price if market prices move lower. This is an attractive option if the goal is to protect a food-importing country against a price surge, because the country will still be able to benefit from lower prices after the agreement. Thus, a call option provides greater flexibility than a futures contract. However, this flexibility comes at a cost - call options are more expensive than futures contracts - and governments must be willing to pay the premium. Depending on the fiscal situation of the particular government, and their dependence on imports, some governments may decide to self-insure, paying high prices on occasion but avoiding the fees involved in purchasing call options year in and year out.

\section{Coping with price volatility after the fact: targeted safety nets and emergency food reserves}

\section{Key message}

In order to be effective at reducing the negative consequences of price volatility, targeted safety-net mechanisms must be designed in advance and in consultation with the most vulnerable people.

Surges in food prices and increases in the prices of inputs such as fertilizers reduce the incomes of poor and vulnerable households and put stress on family budgets. In response, households sell off assets, take children out of school or change their diets to include cheaper, less nutritious ingredients, all of which have consequences that last long after the price surge has receded. The long-lasting nature of such impacts provides both a humanitarian and an economic rationale for safety nets that mitigate the impact of the shock. School feeding programmes, for example, can help to prevent children from leaving school during a crisis, thus reducing the long-term impact of the price shock on human capital.

For poor consumers, scaling-up existing safety nets is a viable option in countries where these are already in place. This could be achieved by adding new beneficiaries, by increasing transfers made to current beneficiaries or both.
However, such safety nets require a lot of resources. This presents an obstacle, especially for low-income developing countries, which cannot afford such expenditures in times of crisis. Foreign support will have to be mobilized quickly to enable these countries to meet the increased demand on their budgets.

Another difficulty is that many countries do not already have safety-net mechanisms in place. It is of critical importance to design safety net mechanisms ex ante, even if funds are not sufficient to implement them at first. Having identified the vulnerable, particularly pregnant and lactating women and children under two years of age, the safety net or emergency food reserve could be activated as soon as a crisis hits, using funds from the international community. For example, a key component of many safety nets, particularly social cash transfers, is the delivery of cash to women, which can enhance their status in the community and within the household as well as resulting in better health and nutrition outcomes for children. But such interventions require careful planning if they are to be effective, not a rushed approach in response to a crisis. Planning ahead will lead to better outcomes.

If safety nets are provided in terms of food (as opposed to cash), emergency reserves will be needed before the food aid arrives, including specialized foods for children aged six 
months to two years. These reserves should be well linked to effective information and early warning systems. They should be strategically located, taking into account trade-offs between increased monitoring costs when the reserve is too fragmented, the higher costs involved if it were stored entirely in food-deficit areas and the longer response time entailed if it were stored entirely in food-surplus areas. The size of the reserve should also be carefully determined. At a minimum, it should provide for 1-2 months of requirements, depending on how long it takes to replenish supplies; at most it should be enough to meet the food requirements of only the vulnerable, not to provide general subsidies to all.

Food reserve agencies should operate with well-defined rules and enjoy autonomy from the political process, similar to that of a central bank. When it is necessary to replenish reserves, the agency should purchase stocks in a way that does not increase uncertainty for private traders, who should handle the bulk of the crop. Food reserve agencies should also collaborate across borders in order to pool risks more efficiently. The recently expanded ASEAN (Association of Southeast Asian Nations) Plus Three emergency rice reserve is a promising development in this regard.

In cases where countries may not have the capacity to operate national emergency reserves, strategic food-reserve systems could be established at the regional level. In regions where food crises are likely to recur and transport infrastructure is weak, such emergency reserves can quickly provide food to the hungry. In 2008, WFP achieved rapid and cost-effective food delivery to beneficiaries across countries in the Eastern and Southern Africa region through a pilot forward purchase facility scheme implemented at a regional level. Any such regional system should provide the foundation for an eventual transition to national ownership and control.

Some nations that imposed export restrictions during 2008 and 2010 made exemptions for purchases of humanitarian food, including those by WFP. However, others have not made such exemptions, forcing humanitarian agencies to purchase food from more distant sources. Most exemptions, if made, are on a case-by-case basis after concern has been raised and the exemption requested. This results in loss of valuable emergency response time and resources, as procurement teams have to spend time negotiating for exemptions or finding alternative suppliers from other regions.

Many nations have agreed to commit to exempt humanitarian purchases from export bans, first at the G8 Summit in L'Aquila, Italy, in July 2009 and then at the World
Summit on Food Security in Rome in November 2009, where all FAO member states agreed to "remove food export restrictions or extraordinary taxes for food purchased for non-commercial humanitarian purposes, and to consult and notify in advance before imposing any such new restrictions". This commitment was also made at the G20 Agriculture Ministers' Meeting in June 2011 (see Box 11). If honoured, these commitments would allow food to be shipped rapidly to where it is needed in an emergency.

While price surges will benefit farmers with a surplus to sell, producer safety nets may help protect the livelihoods of some smallholder farmers if there is a significant and rapid increase in the international price of fertilizers or other inputs. Higher prices for these inputs, coupled with the fact that inputs must be purchased several months before the harvest, may mean that farmers are forced to curtail their use, which could reduce yields and have negative effects on the livelihood of smallholders.

Targeted input support enhances the ability of smallholders to respond to the increase in food prices and contributes towards household and national food security. However, targeted input subsidies involve high costs, and such programmes are difficult to manage, especially during periods characterized by volatile food and input prices. For example, it is typically very difficult to make sure that fertilizer is delivered on time to farmers. Even if this problem is solved, political pressures for expansion of input support programmes may lead to an unsustainable fiscal burden that may hinder rather than promote long-run growth. Therefore, it is important that such programmes are temporary and target only those farmers that have no means to finance input purchases. ${ }^{69}$

At the international level, it can be difficult for many poor countries to afford the higher import bills that come with food price spikes. During the recent price surge, a number of countries that experienced significant increases in their food and fertilizer import bills resorted to the International Monetary Fund's Exogenous Shock Facility (ESF). The ESF provides liquidity to mitigate the negative impact of exogenous shocks on developing countries' balance of payments, international reserves position and inflation. Such facilities could be expanded to enable a country to finance food imports when the need arises, rather than to compensate them for balance of payment losses after the fact. Mechanisms such as the World Bank's Global Food Crisis Response Programme, which is targeted at the poorest and most vulnerable countries, should be supported, as well as efforts for a broader crisis window under the International Development Association. 


\section{Outcomes of the G20 Agriculture Ministers' Meeting}

On 23 June 2011, G20 Agriculture Ministers met to tackle the issue of food price volatility, with the ultimate objective to improve food security. They agreed on an "Action Plan on food price volatility and agriculture" that will be submitted to the G20 Leaders at their summit in November 2011. The discussions were based on an Inter-agency Report on Food Price Volatility prepared by FAO, OECD, IFAD, IMF, the United Nations Conference on Trade and Development (UNCTAD), WFP, the World Bank, the World Trade Organization (WTO), International Food Policy Research Institute (IFPRI), and the UN High-Level Task Force on Global Food Security. The effort of these ten international organizations was coordinated by FAO and OECD. The report put forward a number of concrete policy options aimed at reducing volatility and mitigating its negative effects on countries and the vulnerable.

The G20 Agriculture Ministers' Meeting adopted several recommendations put forward by the Inter-agency report. Among these recommendations are:

1. Agricultural production and productivity: $G 20$ governments committed to implementing a broad scope of actions to boost agricultural productivity growth, increase food production and strengthen the longer-term sustainability and resilience of the food and agriculture system, paying special attention to smallholders, especially women and young farmers. Such actions will include strengthening agricultural research and innovation and creating the enabling environment to encourage public and private investment in agriculture.

2. Market information and transparency: $G 20$ governments will launch the Agricultural Market Information System (AMIS) to increase collaboration among international organizations, major food exporting and importing countries and the private sector with the objective of providing accurate and transparent information. AMIS will be based on existing information mechanisms and will be housed in FAO.

3. International policy coordination: $\mathrm{G} 20$ governments also called for the establishment of a Rapid Response Forum within AMIS to enhance international policy coordination. The Rapid Response Forum will discuss appropriate policy responses when the market situation indicates a high risk of food insecurity and will work closely with the Committee on World Food Security (CFS) to promote greater international policy convergence.

4. Reducing the effects of price volatility on the most vulnerable: G20 Agriculture Ministers called upon multilateral development banks and international organizations to develop risk management tools and help mainstream risk management, in particular for smallholders, and to further explore counter-cyclical mechanisms for vulnerable countries in the event of external shocks, including food price surges. The Ministers also supported initiatives to maximize efficient delivery of food assistance and strengthen supply chains against price and supply shocks, in particular through forward-positioning networks and mainstreaming risk management in international food-assistance procurement. The $\mathrm{G} 20$ also agreed to remove export restrictions and extraordinary taxes for food purchased for non-commercial humanitarian purposes by WFP, and agreed not to impose them in the future.

5. Financial regulation: $\mathrm{G} 20$ Agriculture Ministers strongly encouraged G20 Finance Ministers to take the appropriate decisions for better regulation and supervision of agricultural futures and derivative markets. 


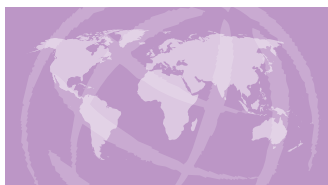

\section{Preventing price volatility in the long term: increasing the productivity, sustainability and resilience of agriculture}

\section{Key message}

Investment in agriculture will improve the competitiveness of domestic production, increase farmers' profits and make food more affordable for the poor. Private investment will form the bulk of this investment, but public investment has a catalytic role to play in supplying public goods that the private sector will not provide. These investments should consider the rights of existing users of land and related natural resources, benefit local communities, promote food security and not cause undue harm to the environment.

The global agriculture sector faces significant challenges in the coming four decades. Continued population growth will drive up food demand, while climate change and natural resource degradation will create challenges on the supply side, both in terms of average production and in terms of production volatility. FAO estimates indicate that global agricultural production will need to grow by 70 percent between 2005-07 and 2050, and by almost 100 percent in developing countries, to feed a population of more than 9 billion people in 2050. Insufficient growth in production will lead to higher and more volatile prices.

It is important to note that increased production at the farm level is not the only way to increase supplies and meet demand. FAO recently estimated that 1.3 billion tonnes of food are lost or wasted globally each year. Most of the waste is in developed countries and most of the losses are in developing countries. The challenge is to find cost-effective ways to reduce such waste and losses. Thus, research and investment in improved post-harvest management and logistics will be an important component of a broader agricultural development strategy.

Investment to create a more productive and efficient agriculture sector will make food more affordable for the poor and reduce price volatility as well. In addition, there is clear demand for such investment from the rural poor themselves. According to Gallup polls in sub-Saharan Africa, people think that agriculture is the most important issue for their governments to address, and they rank reducing poverty and hunger as the two most important of the Millennium Development Goals. ${ }^{70}$ Increased investment will lead to more rapid agricultural growth, which has been shown to have a greater positive impact on the income of the poor than growth from outside agriculture (Figure 17). ${ }^{71}$ Greater income for the poor will make households less vulnerable to economic shocks such as price fluctuations and reduce the danger of poverty traps.

There are encouraging signs that agricultural capital stocks - buildings, equipment, livestock and the like - may be starting to increase. Agricultural capital per worker was largely stagnant in low- and middle-income countries from the middle of the 1980s to the early part of the 2000s, but increased in 2004 and 2005, the most recent years for which data are available. ${ }^{72}$ These increases need to be sustained over long periods of time: doubling the agricultural output of developing countries will require an average annual gross investment of US\$209 billion (in 2009 US dollars), roughly

\section{FIGURE 17}

An increase in agricultural growth has a stronger more positive impact on the income of the poor than does an equivalent increase in non-agricultural growth

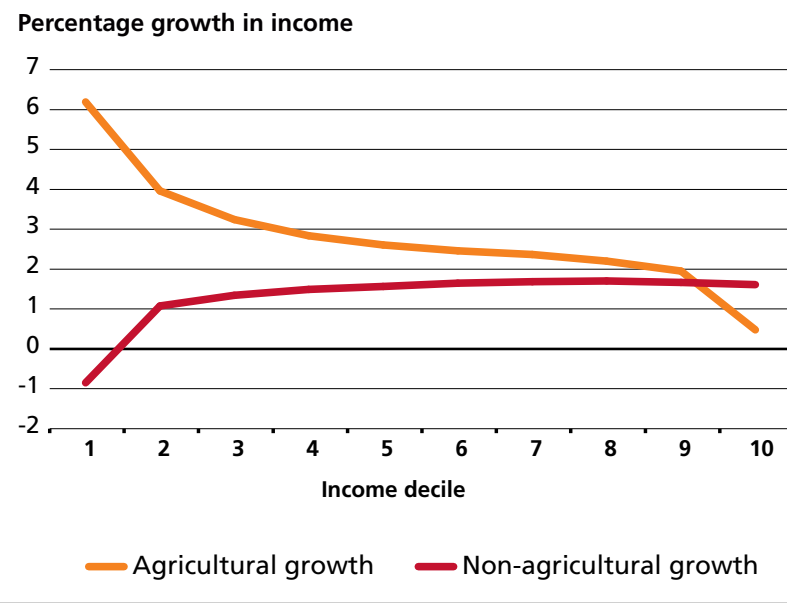

Note: Income decile 1 refers to the poorest 10 percent of the population, and so on. Expenditure is used as a proxy for income, as is common in analysis of household survey data. Source: E. Ligon and E. Sadoulet. 2007. Estimating the effects of aggregate agricultural growth on the distribution of expenditures. Background paper for the World Development Report 2008 (available at http://siteresources.worldbank.org/INTWDR2008/Resources/ 2795087-1191427986785/LigonE\&SadouletE_EstimatingEffectsOfAggAgGr.pdf). 
50 percent more than current levels. ${ }^{73}$ This total includes investment needed in primary agriculture and necessary downstream services such as storage and processing facilities, but does not include public goods such as roads, large-scale irrigation projects and electrification that are also needed. Delivering investment on this scale is a formidable challenge, but one that must be met if the world is to eliminate hunger.

Most of the investment, both in primary agriculture and downstream sectors, will have to come from private sources. Farmers themselves must purchase implements and machinery, make investments to improve soil fertility and acquire knowledge to improve the management of their farms. Private-sector investment also needs to be encouraged at all stages in the value chain - upstream of the farm, in seed and fertilizer production and distribution, and downstream, in processing, marketing and distribution.

Farmers and prospective farmers will invest in agriculture only if their investments are profitable, however, and this requires an appropriate policy and regulatory environment as well as investment in a wide range of public goods. Three types of public investment are critical:

- $\quad$ direct investment in agricultural research and development to increase productivity and to enhance the ability of agricultural systems, especially smallholder farms, to cope with climate change and resource scarcity;

- $\quad$ investments to link the primary agriculture sector with the sources of demand, including agricultural institutions, extension services, rural roads, ports, power, storage and irrigation systems; and

- non-agricultural investment to enhance the rural institutional environment and improve human wellbeing; such investments include education, particularly of women, sanitation and clean water supply, and health care.

All of these investments have been shown to have consistently high rates of return, both in financial terms and in terms of reducing poverty. ${ }^{74}$ Investment to increase the productivity and resilience of developing country agriculture can contribute to improving food security in multiple ways. It can reduce food price volatility through increased productivity and improved technical management of production and of risk, especially in the face of climate change. It can help farmers and households to cope better with the effects of volatility once it occurs. It can also make food more affordable for poor consumers and increase the incomes of poor farmers. These investments will be more effective at reducing poverty if they are appropriate for small-scale farmers, who will account for a substantial share of production in developing countries for the foreseeable future.

Much public research is carried out by the international research centres of the Consultative Group on International Agricultural Research (CGIAR), although public research institutes in countries such as Brazil, China and India are providing an increasing share of public goods in the area of agricultural research. A new multi-donor trust fund, the CGIAR Fund, has been established to harmonize donor investments in key global challenges on agriculture and is being hosted and managed by the World Bank. New resultsoriented research programmes focus on policies and technologies to mitigate climate change and adapt to its effects; these include a broad group of partners. There is a need to increase and sustain the financing of such bodies in order that they may continue to invest today in the techniques and innovations that will be needed to deal with the food security and climate challenges that will be faced in the future.

Increasing public investment in transport and productive infrastructure, as well as in human capital, is also central to stimulating productivity and reducing post-harvest wastage. Improvements to infrastructure, in particular rural roads, irrigation and market facilities such as warehouses, cold storage facilities and market-information systems, will reduce transport costs, integrate smallholders into markets and reduce price volatility. Improvements to extension, education and health are also key elements of a sound policy approach to increasing the productivity and enhancing the food security and the well-being of farmers and consumers.

These types of investment in human capital, infrastructure and science are very basic, but they are nevertheless essential to enable the poor to lift themselves out of poverty. It is hard to imagine that food insecurity will be eradicated if they are not made. We have made progress in alleviating poverty and food insecurity and can do more if we build on sound analysis, good science and adequate funding for appropriate interventions. This will require the commitment of the entire international community to raising the profile of agriculture, not just for the next year or two but ultimately until everyone, at all times, has physical, social and economic access to sufficient, safe and nutritious food that meets their dietary needs and food preferences for an active and healthy life. 


\section{ANNEX TABLE}

Prevalence of undernourishment and progress towards the World Food Summit (WFS) ${ }^{1}$ and the Millennium Development Goal (MDG) ${ }^{2}$ targets in developing countries ${ }^{3}$

\begin{tabular}{|c|c|c|c|c|c|c|c|c|c|c|c|c|c|}
\hline \multirow{3}{*}{$\begin{array}{l}\text { WORLD } \\
\text { Region/subregion/country }\end{array}$} & \multirow{2}{*}{$\begin{array}{c}\begin{array}{c}\text { Total } \\
\text { population }\end{array} \\
2006-08\end{array}$} & \multicolumn{6}{|c|}{ Number of people undernourished } & \multicolumn{6}{|c|}{ Proportion of undernourished in total population } \\
\hline & & $1990-92$ & 1995-97 & $2000-02$ & $2006-08$ & $\begin{array}{l}\text { Change } \\
\text { so far }\end{array}$ & $\begin{array}{l}\text { Progress } \\
\text { towards }\end{array}$ & $1990-92$ & 1995-97 & $2000-02$ & $2006-08$ & $\begin{array}{l}\text { Change } \\
\text { so far }\end{array}$ & $\begin{array}{l}\text { Progress } \\
\text { towards }\end{array}$ \\
\hline & (millions) & \multicolumn{4}{|c|}{ (millions) } & (\%) & $\begin{array}{l}\text { target } \\
\text { tars }^{4}\end{array}$ & \multicolumn{4}{|c|}{ (\%) } & (\%) & $\begin{array}{l}\text { IVIDG } \\
\text { target }^{4}\end{array}$ \\
\hline WORLD & 6652.5 & 848.4 & 791.5 & 836.2 & 850.0 & 0.2 & & 16 & 14 & 14 & 13 & -19 & \\
\hline Developed regions & 1231.3 & 15.3 & 17.5 & 15.4 & 10.6 & -30.8 & & - & - & - & - & na & \\
\hline Developing regions & 5420.2 & 833.2 & 774.0 & 820.8 & 839.4 & 0.8 & & 20 & 17 & 17 & 15 & -22 & \\
\hline Least-developed countries ${ }^{5}$ & 796.7 & 211.2 & 249.4 & 244.7 & 263.8 & 24.9 & & 39 & 41 & 35 & 33 & -16 & \\
\hline Landlocked developing countries ${ }^{6}$ & 382.8 & 90.2 & 101.6 & 102.5 & 98.3 & 8.9 & & 34 & 34 & 31 & 26 & -24 & \\
\hline Small island developing states ${ }^{7}$ & 52.2 & 9.6 & 10.9 & 9.7 & 10.7 & 11.8 & & 23 & 24 & 20 & 21 & -10 & \\
\hline AFRICA & 962.9 & 170.9 & 193.6 & 203.3 & 223.6 & 30.8 & & 26 & 26 & 24 & 23 & -11 & \\
\hline Northern Africa & 161.4 & 5.0 & 5.4 & 5.6 & 6.1 & 23.4 & & - & - & - & - & na & \\
\hline Algeria & 33.9 & ns & 1.5 & 1.4 & ns & na & & - & 5 & 5 & - & na & \\
\hline Egypt & 80.1 & ns & ns & ns & ns & na & & - & - & - & - & na & \\
\hline Libyan Arab Jamahiriya & 6.2 & ns & ns & ns & ns & na & & - & - & - & - & na & \\
\hline Morocco & 31.2 & 1.5 & 1.6 & 1.6 & ns & na & & 6 & 6 & 6 & - & na & \\
\hline Tunisia & 10.1 & ns & ns & ns & ns & na & & - & - & - & - & na & \\
\hline Sub-Saharan Africa ${ }^{8}$ & 801.5 & 165.9 & 188.2 & 197.7 & 217.5 & 31.1 & & 31 & 31 & 29 & 27 & -13 & \\
\hline Angola & 17.6 & 7.4 & 7.8 & 7.6 & 7.2 & -2.4 & & 67 & 61 & 52 & 41 & -39 & \\
\hline Benin & 8.4 & 1.0 & 1.0 & 1.0 & 1.0 & -0.3 & & 20 & 18 & 15 & 12 & -41 & t \\
\hline Botswana & 1.9 & 0.3 & 0.4 & 0.5 & 0.5 & 85.4 & & 19 & 23 & 27 & 25 & 36 & \\
\hline Burkina Faso & 14.7 & 1.2 & 1.2 & 1.4 & 1.2 & -3.0 & & 14 & 12 & 12 & 8 & -40 & \\
\hline Burundi & 7.8 & 2.5 & 3.5 & 3.9 & 4.9 & 93.8 & & 44 & 56 & 59 & 62 & 43 & \\
\hline Cameroon & 18.7 & 4.2 & 5.0 & 4.3 & 4.2 & -0.5 & & 33 & 34 & 26 & 22 & -33 & \\
\hline Central African Republic & 4.3 & 1.3 & 1.6 & 1.6 & 1.7 & 30.2 & & 44 & 47 & 43 & 40 & -8 & \\
\hline Chad & 10.6 & 3.8 & 3.9 & 3.7 & 4.1 & 8.3 & & 60 & 53 & 43 & 39 & -36 & \\
\hline Congo & 3.6 & 1.0 & 1.2 & 0.6 & 0.5 & -55.4 & & 42 & 41 & 20 & 13 & -68 & \\
\hline Côte d'Ivoire & 20.1 & 1.9 & 2.6 & 2.9 & 2.9 & 50.9 & & 15 & 17 & 17 & 14 & -2 & \\
\hline Eritrea & 4.8 & 2.1 & 2.1 & 2.7 & 3.1 & 44.9 & & 67 & 64 & 70 & 65 & -4 & \\
\hline Ethiopia & 78.7 & 34.7 & 36.2 & 32.6 & 32.6 & -6.1 & & 69 & 62 & 48 & 41 & -40 & \\
\hline Gabon & 1.4 & 0.1 & ns & ns & ns & na & & 6 & - & - & - & na & \\
\hline Gambia & 1.6 & 0.1 & 0.3 & 0.3 & 0.3 & 143.9 & & 14 & 23 & 21 & 19 & 41 & \\
\hline Ghana & 22.9 & 4.3 & 2.3 & 1.9 & 1.1 & -74.0 & & 28 & 13 & 9 & 5 & -83 & \\
\hline Guinea & 9.6 & 1.3 & 1.5 & 1.7 & 1.6 & 23.5 & & 20 & 19 & 20 & 16 & -18 & 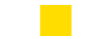 \\
\hline Kenya & 37.8 & 8.1 & 9.0 & 10.6 & 12.4 & 54.1 & & 33 & 32 & 33 & 33 & -1 & 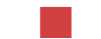 \\
\hline
\end{tabular}


ANNEX TABLE

Prevalence of undernourishment and progress towards the World Food Summit (WFS) ${ }^{1}$ and the Millennium Development Goal (MDG) ${ }^{2}$ targets in developing countries ${ }^{3}$

\begin{tabular}{|c|c|c|c|c|c|c|c|c|c|c|c|c|c|}
\hline \multirow{3}{*}{$\begin{array}{l}\text { WORLD } \\
\text { Region/subregion/country }\end{array}$} & \multirow{2}{*}{$\begin{array}{c}\begin{array}{c}\text { Total } \\
\text { population }\end{array} \\
2006-08\end{array}$} & \multicolumn{6}{|c|}{ Number of people undernourished } & \multicolumn{6}{|c|}{ Proportion of undernourished in total population } \\
\hline & & 1990-92 & 1995-97 & $2000-02$ & $2006-08$ & $\begin{array}{l}\text { Change } \\
\text { so far }\end{array}$ & $\begin{array}{l}\text { Progress } \\
\text { towards }\end{array}$ & 1990-92 & 1995-97 & $2000-02$ & $2006-08$ & $\begin{array}{l}\text { Change } \\
\text { so far }\end{array}$ & $\begin{array}{l}\text { Progress } \\
\text { towards }\end{array}$ \\
\hline & (millions) & \multicolumn{4}{|c|}{ (millions) } & (\%) & target $^{4}$ & \multicolumn{4}{|c|}{ (\%) } & (\%) & target $^{4}$ \\
\hline Lesotho & 2.0 & 0.2 & 0.3 & 0.3 & 0.3 & 15.6 & & 15 & 16 & 14 & 14 & -7 & \\
\hline Liberia & 3.6 & 0.6 & 0.7 & 1.1 & 1.1 & 85.0 & & 30 & 32 & 36 & 32 & 7 & \\
\hline Madagascar & 18.6 & 2.4 & 3.5 & 4.4 & 4.7 & 98.7 & & 21 & 26 & 28 & 25 & 24 & \\
\hline Malawi & 14.4 & 4.2 & 3.8 & 3.6 & 3.9 & -5.9 & & 43 & 36 & 30 & 27 & -37 & \\
\hline Mali & 12.4 & 2.4 & 2.5 & 1.9 & 1.5 & -38.1 & & 27 & 25 & 18 & 12 & -56 & \\
\hline Mauritania & 3.1 & 0.2 & 0.2 & 0.2 & 0.2 & 1.9 & & 12 & 9 & 8 & 8 & -34 & \\
\hline Mauritius & 1.3 & 0.1 & 0.1 & 0.1 & 0.1 & -17.2 & & 7 & 7 & 5 & 5 & -30 & \\
\hline Mozambique & 21.9 & 8.2 & 7.8 & 8.5 & 8.3 & 0.8 & & 59 & 47 & 46 & 38 & -36 & \\
\hline Namibia & 2.1 & 0.5 & 0.5 & 0.4 & 0.4 & -18.5 & & 32 & 30 & 21 & 18 & -43 & \\
\hline Niger & 14.1 & 3.0 & 3.5 & 3.1 & 2.3 & -22.2 & & 37 & 37 & 27 & 16 & -55 & \\
\hline Nigeria & 147.7 & 16.3 & 10.9 & 11.9 & 9.4 & -42.3 & & 16 & 10 & 9 & 6 & -61 & \\
\hline Rwanda & 9.5 & 3.0 & 3.0 & 3.1 & 3.0 & 0.3 & & 44 & 53 & 38 & 32 & -28 & \\
\hline Senegal & 11.9 & 1.7 & 2.3 & 2.6 & 2.3 & 32.4 & & 22 & 26 & 26 & 19 & -14 & \\
\hline Sierra Leone & 5.4 & 1.8 & 1.6 & 1.9 & 1.9 & 3.6 & & 45 & 39 & 43 & 35 & -22 & \\
\hline South Africa & 49.2 & ns & ns & ns & ns & na & & - & - & - & - & na & \\
\hline Sudan & 40.4 & 10.8 & 9.3 & 9.8 & 8.8 & -17.9 & & 39 & 29 & 28 & 22 & -44 & \\
\hline Swaziland & 1.2 & 0.1 & 0.2 & 0.2 & 0.2 & 110.9 & & 12 & 21 & 18 & 19 & 63 & \\
\hline Togo & 6.3 & 1.7 & 1.7 & 1.9 & 1.9 & 7.6 & & 43 & 36 & 36 & 30 & -31 & \\
\hline Uganda & 30.6 & 3.5 & 4.9 & 4.8 & 6.7 & 92.5 & & 19 & 23 & 19 & 22 & 15 & \\
\hline United Republic of Tanzania & 41.3 & 7.7 & 12.8 & 14.0 & 13.9 & 79.9 & & 29 & 42 & 40 & 34 & 15 & \\
\hline Zambia & 12.3 & 2.9 & 3.6 & 4.7 & 5.4 & 86.5 & & 35 & 38 & 43 & 44 & 23 & \\
\hline Zimbabwe & 12.5 & 4.3 & 5.3 & 5.1 & 3.7 & -14.1 & & 40 & 44 & 41 & 30 & -26 & \\
\hline ASIA & 3884.3 & 607.1 & 526.2 & 565.7 & 567.8 & -6.5 & & 20 & 16 & 16 & 15 & -27 & \\
\hline Caucasus and Central Asia & 75.4 & 10.9 & 9.2 & 12.4 & 6.7 & -38.8 & & 16 & 13 & 17 & 9 & -45 & \\
\hline Armenia & 3.1 & 1.6 & 1.1 & 0.9 & 0.6 & na & & 45 & 36 & 28 & 21 & -53 & \\
\hline Azerbaijan & 8.6 & 2.0 & 2.2 & 0.9 & ns & -90.2 & & 27 & 27 & 11 & - & na & \\
\hline Georgia & 4.4 & 3.1 & 1.0 & 0.5 & 0.3 & -91.8 & & 58 & 19 & 12 & 6 & -90 & \\
\hline Kazakhstan & 15.4 & ns & ns & 1.2 & ns & na & & - & - & 8 & - & na & \\
\hline Kyrgyzstan & 5.3 & 0.8 & 0.6 & 0.9 & 0.6 & -24.4 & 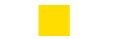 & 17 & 13 & 17 & 11 & -37 & \\
\hline Tajikistan & 6.7 & 1.8 & 2.4 & 2.9 & 1.8 & -4.6 & & 34 & 42 & 46 & 26 & -23 & \\
\hline Turkmenistan & 5.0 & 0.3 & 0.4 & 0.4 & 0.3 & 0.9 & & 9 & 9 & 9 & 7 & -23 & \\
\hline
\end{tabular}




\section{ANNEX TABLE}

Prevalence of undernourishment and progress towards the World Food Summit (WFS) ${ }^{1}$ and the Millennium Development Goal (MDG) ${ }^{2}$ targets in developing countries ${ }^{3}$

\begin{tabular}{|c|c|c|c|c|c|c|c|c|c|c|c|c|c|}
\hline \multirow{3}{*}{$\begin{array}{l}\text { WORLD } \\
\text { Region/subregion/country }\end{array}$} & \multirow{3}{*}{$\begin{array}{c}\begin{array}{c}\text { Total } \\
\text { population }\end{array} \\
2006-08 \\
\text { (millions) }\end{array}$} & \multicolumn{6}{|c|}{ Number of people undernourished } & \multicolumn{6}{|c|}{ Proportion of undernourished in total population } \\
\hline & & 1990-92 & 1995-97 & $2000-02$ & $2006-08$ & $\begin{array}{l}\text { Change } \\
\text { so far }\end{array}$ & $\begin{array}{l}\text { Progress } \\
\text { towards }\end{array}$ & 1990-92 & 1995-97 & $2000-02$ & $2006-08$ & $\begin{array}{l}\text { Change } \\
\text { so far }\end{array}$ & $\begin{array}{l}\text { Progress } \\
\text { towards }\end{array}$ \\
\hline & & \multicolumn{4}{|c|}{ (millions) } & (\%) & $\begin{array}{c}\text { WFS } \\
\text { target }^{4}\end{array}$ & \multicolumn{4}{|c|}{ (\%) } & $(\%)$ & $\begin{array}{l}\text { MDG } \\
\text { target }^{4}\end{array}$ \\
\hline Uzbekistan & 26.9 & 1.1 & 1.2 & 4.7 & 2.8 & 152.6 & & 5 & 5 & 19 & 11 & 97 & \\
\hline Eastern Asia & 1410.8 & 215.6 & 149.5 & 141.8 & 139.4 & -35.3 & & 18 & 12 & 10 & 10 & -44 & \\
\hline China & 1336.5 & 210.0 & 141.7 & 132.8 & 129.6 & -38.3 & $\square$ & 18 & 12 & 10 & 10 & -46 & \\
\hline Dem. People's Rep. of Korea & 23.7 & 4.2 & 6.6 & 7.8 & 8.4 & 99.6 & & 21 & 30 & 34 & 35 & 72 & \\
\hline Mongolia & 2.6 & 0.6 & 0.8 & 0.6 & 0.7 & 11.4 & & 28 & 33 & 27 & 27 & -5 & \\
\hline Republic of Korea & 48.0 & ns & ns & ns & ns & na & 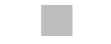 & - & - & - & - & na & \\
\hline Eastern Asia - excluding China & 74.3 & 5.5 & 7.9 & 9.0 & 9.8 & 77.1 & & 8 & 11 & 13 & 13 & 57 & \\
\hline Southern Asia ${ }^{9}$ & 1642.8 & 267.5 & 269.0 & 307.9 & 330.1 & 23.4 & & 22 & 20 & 21 & 20 & -8 & \\
\hline Bangladesh & 157.7 & 44.4 & 54.2 & 42.3 & 41.4 & -6.8 & & 38 & 41 & 30 & 26 & -30 & \\
\hline India & 1164.6 & 177.0 & 167.1 & 208.0 & 224.6 & 26.9 & & 20 & 17 & 20 & 19 & -4 & \\
\hline Iran (Islamic Republic of) & 72.4 & ns & ns & ns & ns & na & 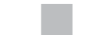 & - & - & - & - & na & \\
\hline Nepal & 28.3 & 4.2 & 4.4 & 4.6 & 4.7 & 13.3 & 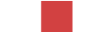 & 21 & 20 & 18 & 17 & -22 & \\
\hline Pakistan & 173.2 & 29.5 & 26.8 & 36.3 & 42.8 & 45.0 & & 25 & 20 & 24 & 25 & -1 & \\
\hline Sri Lanka & 19.9 & 4.8 & 4.5 & 3.9 & 3.9 & -18.4 & & 28 & 25 & 20 & 20 & -28 & \\
\hline Southern Asia - excluding India & 478.1 & 90.5 & 101.9 & 99.9 & 105.5 & 16.7 & & 26 & 26 & 23 & 22 & -16 & \\
\hline South-Eastern Asia ${ }^{10}$ & 564.0 & 105.8 & 86.0 & 89.6 & 77.4 & -26.9 & 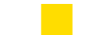 & 24 & 18 & 17 & 14 & -42 & \\
\hline Cambodia & 14.3 & 3.8 & 4.7 & 3.8 & 3.6 & -4.5 & 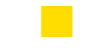 & 38 & 40 & 29 & 25 & -33 & \\
\hline Indonesia & 224.7 & 28.9 & 22.0 & 30.4 & 29.7 & 2.9 & 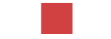 & 16 & 11 & 15 & 13 & -17 & \\
\hline Lao People's Dem. Rep. & 6.1 & 1.3 & 1.4 & 1.4 & 1.4 & 3.1 & & 31 & 29 & 26 & 22 & -27 & \\
\hline Malaysia & 26.6 & ns & ns & ns & ns & na & & - & - & - & - & na & \\
\hline Philippines & 88.7 & 15.3 & 14.1 & 14.6 & 11.8 & -22.9 & 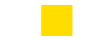 & 24 & 20 & 18 & 13 & -44 & \\
\hline Thailand & 67.0 & 15.0 & 11.1 & 11.5 & 10.7 & -28.9 & 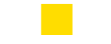 & 26 & 18 & 18 & 16 & -39 & \\
\hline Viet Nam & 86.1 & 21.0 & 16.7 & 13.3 & 9.6 & -54.5 & 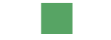 & 31 & 22 & 17 & 11 & -64 & \\
\hline Western Asia ${ }^{11}$ & 191.3 & 7.4 & 12.5 & 13.9 & 14.2 & 93.0 & & 6 & 8 & 8 & 7 & 32 & \\
\hline Jordan & 5.9 & ns & 0.2 & 0.2 & ns & na & & - & 5 & 5 & - & na & \\
\hline Kuwait & 2.8 & 0.4 & 0.1 & 0.1 & 0.1 & -65.7 & & 20 & 5 & 6 & 5 & -75 & \\
\hline Lebanon & 4.2 & ns & ns & ns & ns & na & 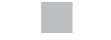 & - & - & - & - & na & \\
\hline Saudi Arabia & 24.7 & ns & ns & ns & ns & na & 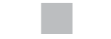 & - & - & - & - & na & \\
\hline Syrian Arab Republic & 20.5 & ns & ns & ns & ns & na & & - & - & - & - & na & \\
\hline Turkey & 73.0 & ns & ns & ns & ns & na & & - & - & - & - & na & \\
\hline United Arab Emirates & 4.4 & ns & ns & ns & ns & na & 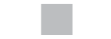 & - & - & - & - & na & 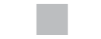 \\
\hline Yemen & 22.3 & 3.8 & 5.0 & 5.7 & 6.7 & 75.3 & 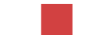 & 30 & 31 & 31 & 30 & 2 & 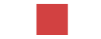 \\
\hline
\end{tabular}


ANNEX TABLE

Prevalence of undernourishment and progress towards the World Food Summit (WFS) ${ }^{1}$ and the Millennium Development Goal (MDG) ${ }^{2}$ targets in developing countries ${ }^{3}$

\begin{tabular}{|c|c|c|c|c|c|c|c|c|c|c|c|c|c|}
\hline \multirow{4}{*}{$\begin{array}{l}\text { WORLD } \\
\text { Region/subregion/country } \\
\text { LATIN AMERICA AND THE CARIBBEAN }\end{array}$} & \multirow{4}{*}{$\begin{array}{c}\begin{array}{c}\text { Total } \\
\text { population }\end{array} \\
2006-08 \\
\text { (millions) } \\
564.3\end{array}$} & \multicolumn{6}{|c|}{ Number of people undernourished } & \multicolumn{6}{|c|}{ Proportion of undernourished in total population } \\
\hline & & 1990-92 & 1995-97 & $2000-02$ & $2006-08$ & $\begin{array}{l}\text { Change } \\
\text { so far }\end{array}$ & \multirow{2}{*}{$\begin{array}{c}\text { Progress } \\
\text { towards } \\
\text { WFS } \\
\text { target }^{4}\end{array}$} & 1990-92 & 1995-97 & $2000-02$ & $2006-08$ & $\begin{array}{l}\text { Change } \\
\text { so far }\end{array}$ & \multirow{2}{*}{$\begin{array}{c}\text { Progress } \\
\text { towards } \\
\text { MDG } \\
\text { target }^{4}\end{array}$} \\
\hline & & \multicolumn{4}{|c|}{ (millions) } & $(\%)$ & & \multicolumn{4}{|c|}{ (\%) } & $(\%)$ & \\
\hline & & 54.4 & 53.4 & 50.8 & 47.0 & -13.7 & & 12 & 11 & 10 & 8 & -32 & \\
\hline Caribbean $^{12}$ & 36.1 & 7.7 & 8.9 & 7.4 & 8.3 & 7.6 & & 25 & 28 & 22 & 23 & -10 & \\
\hline Cuba & 11.2 & 0.6 & 1.5 & ns & ns & na & & 6 & 14 & - & - & na & \\
\hline Dominican Republic & 9.8 & 2.1 & 2.1 & 2.2 & 2.3 & 11.7 & & 28 & 26 & 25 & 24 & -14 & \\
\hline Haiti & 9.7 & 4.6 & 4.8 & 4.7 & 5.5 & 21.7 & & 63 & 60 & 53 & 57 & -9 & \\
\hline Jamaica & 2.7 & 0.3 & 0.2 & 0.1 & 0.1 & -52.3 & & 11 & 6 & 5 & 5 & -58 & \\
\hline Trinidad and Tobago & 1.3 & 0.1 & 0.2 & 0.1 & 0.2 & 14.2 & & 11 & 14 & 11 & 11 & 6 & \\
\hline Latin America $^{13}$ & 528.2 & 46.7 & 44.5 & 43.4 & 38.6 & -17.2 & & 11 & 10 & 9 & 7 & -35 & \\
\hline Argentina & 39.5 & ns & ns & ns & ns & na & & - & - & - & - & na & \\
\hline Bolivia (Plurinational State of) & 9.5 & 2.0 & 1.9 & 1.9 & 2.5 & 29.7 & & 29 & 24 & 22 & 27 & -7 & \\
\hline Brazil & 190.1 & 17.1 & 16.6 & 16.2 & 11.7 & -31.5 & & 11 & 10 & 9 & 6 & -45 & \\
\hline Chile & 16.6 & 0.9 & ns & ns & ns & na & & 7 & - & - & - & na & \\
\hline Colombia & 44.4 & 5.2 & 4.0 & 3.9 & 4.1 & -20.7 & & 15 & 11 & 10 & 9 & -40 & \\
\hline Costa Rica & 4.5 & ns & ns & ns & ns & na & & - & - & - & - & na & \\
\hline Ecuador & 13.3 & 2.4 & 1.8 & 2.1 & 2.0 & -16.1 & & 23 & 16 & 17 & 15 & -34 & \\
\hline El Salvador & 6.1 & 0.7 & 0.7 & 0.4 & 0.6 & -17.6 & & 13 & 12 & 7 & 9 & -27 & \\
\hline Guatemala & 13.4 & 1.4 & 2.1 & 2.5 & 2.9 & 113.4 & & 15 & 20 & 22 & 22 & 46 & \\
\hline Guyana & 0.8 & 0.2 & 0.1 & 0.1 & 0.1 & -60.6 & & 20 & 11 & 7 & 8 & -61 & \\
\hline Honduras & 7.2 & 1.0 & 0.9 & 0.9 & 0.9 & -10.6 & & 19 & 16 & 14 & 12 & -37 & 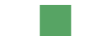 \\
\hline Mexico & 107.5 & ns & ns & ns & ns & na & & - & - & - & - & na & . \\
\hline Nicaragua & 5.6 & 2.1 & 1.8 & 1.3 & 1.1 & -50.4 & & 50 & 38 & 25 & 19 & -62 & \\
\hline Panama & 3.3 & 0.5 & 0.6 & 0.6 & 0.5 & 10.4 & & 18 & 20 & 19 & 15 & -19 & \\
\hline Paraguay & 6.1 & 0.7 & 0.5 & 0.5 & 0.6 & -11.3 & & 16 & 10 & 10 & 10 & -37 & \\
\hline Peru & 28.5 & 6.1 & 5.0 & 4.7 & 4.5 & -26.1 & & 27 & 21 & 18 & 16 & -42 & \\
\hline Suriname & 0.5 & 0.1 & 0.1 & 0.1 & 0.1 & 27.9 & & 14 & 13 & 15 & 15 & 3 & \\
\hline Uruguay & 3.3 & 0.2 & ns & ns & ns & na & 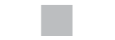 & 5 & - & - & - & na & 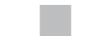 \\
\hline Venezuela (Bolivarian Rep. of) & 27.7 & 2.1 & 3.1 & 3.3 & 1.9 & -6.5 & & 10 & 14 & 13 & 7 & -32 & \\
\hline OCEANIA $^{14}$ & 8.8 & 0.7 & 0.8 & 1.0 & 1.0 & 42.0 & & 12 & 11 & 13 & 12 & -2 & \\
\hline
\end{tabular}


1 The undernourishment estimates referred to in this discussion are calculated using the standard FAO methodology, modified when necessary to take account of incomplete data on production and trade. See FAO. 2008. The State of Food Insecurity in the World 2008. High food prices and food security - threats and opportunities. Rome, p. 7.

2 M. Demeke, G. Pangrazio and M. Maetz. 2009. Country responses to the food security crisis: nature and preliminary implications of the policies pursued. FAO Initiative on Soaring Food Prices (available at ftp://ftp.fao.org/docrep/fao/011/ ak177e/ak177e00.pdf)

3 J. Piesse and C. Thirtle. 2009. Three bubbles and a panic: An explanatory review of recent food commodity price events. Food Policy, 34(2): 119-129; C.L. Gilbert. 2010. How to understand high food prices. Journal of Agricultural Economics, 61: 398425; D. Headey and S. Fan. 2010. Reflections on the global food crisis: how did it happen? How has it hurt? And how can we prevent the next one? IFPRI Research Monograph 165. Washington, DC, International Food Policy Research Institute; D. Headey. 2011. Rethinking the global food crisis: the role of trade shocks. Food Policy, 36(2): 136-146; B. Wright and C. Cafiero. 2011. Grain reserves and food security in the Middle East and North Africa. Food Security, 3(Suppl. 1): S61-S76. FAO. 2009. Insecurity in the World 2009. Economic crises impacts and lessons learned. Rome.

4 Organisation for Economic Co-operation and Development (OECD) and FAO. OECD-FAO Agricultural Outlook 2011 2020 (available at http://www.agrioutlook.org).

5 FAO. 2011. The State of the World's Land and Water Resources for Food and Agriculture. FAO Conference Document C2011/32. Thirty-seventh Session. Rome, 25 June-2 July.

6 World energy markets are much larger than world food commodity markets. Thus, food commodity prices will not have much effect on world energy markets.

7 R. López and G. Galinato. 2007. Should governments stop subsidies to private goods? Evidence from rural Latin America. Journal of Public Economics, 91(5): 1071-1094.

8 FAO. 2009. The State of Food Insecurity in the World 2009. Economic crises impacts and lessons learned. Rome.

9 For a more detailed assessment of the evidence, see D. Dawe, S. Block, A. Gulati,
J. Huang and S. Ito. 2010. Domestic rice price, trade and marketing policies. In S. Pandey, D. Byerlee, D. Dawe, A. Dobermann, S. Mohanty, S. Rozelle and B. Hardy, eds. Rice in the global economy: strategic research and policy issues for food security, pp. 379-407. Los Baños, Philippines, International Rice Research Institute.

10 M.A. Aksoy and A. Isid-Dikmelik. 2008. Are low food prices pro-poor? Net food buyers and sellers in low-income countries. Policy Research Working Paper 4642. Washington, DC, World Bank.

11 M. Ivanic and W. Martin. 2008. Implications of higher global food prices for poverty in low-income countries. Agricultural Economics, 39: 405-416.

12 A. Zezza, B. Davis, C. Azzarri, K. Covarrubias, L. Tasciotti and G. Anríquez. 2008. The impact of rising food prices on the poor. ESA Working Paper 08-07. Rome, FAO (available at ftp://ftp.fao.org/docrep/ fao/011/aj284e/aj284e00.pdf).

13 M. Robles and M. Torero. 2010. Understanding the impact of high food prices in Latin America. Economia, 10(2): 117-164. The difference in findings on impact of higher prices in Peru between Robles and Torero (2010) and Ivanic and Martin (2008) (see note 11) is most likely due to the fact that Robles and Torero used actual price changes, while Ivanic and Martin used a uniform price change across commodities.

14 Dawe et al. (2010) (see note 9).

15 The analysis in this report focuses on staple foods, as does most of the literature on this area. This focus has been driven by the large share of staple foods in the budget of the poor, and by the large price fluctuations for these commodities on world markets. Overall food-price inflation has fewer spikes and smaller increases than staple food prices, but the basket used to calculate food-price inflation is not representative of the budgets of the poor and thus is less relevant from a food-security perspective.

16 S. Block, L. Kiess, P. Webb, S. Kosen, R. Moench-Pfanner, M.W. Bloem and C.P. Timmer. 2004. Macro shocks and micro outcomes: child nutrition during Indonesia's crisis. Economics and Human Biology, 2(1): 21-44.

17 H. Torlesse, L. Kiess and M.W. Bloem. 2003. Association of household rice expenditure with child nutritional status indicates a role for macroeconomic food policy in combating malnutrition. Journal of Nutrition, 133(5): 1320-1325.
18 A. de Brauw. 2011. Migration and child development during the food price crisis in El Salvador. Food Policy, 36(1): 28-40.

19 A. D'Souza and D. Jolliffe. 2010. Rising food prices and coping strategies: household-level evidence from Afghanistan. World Bank Policy Research Working Paper 5466. Washington, DC The World Bank.

20 FAO. 2008. The State of Food Insecurity in the World 2008. High food prices and food security - threats and opportunities. Rome; N. Kumar and A. Quisumbing. 2011. Gendered impacts of the 2007-08 food price crisis: evidence using panel data from rural Ethiopia. IFPRI Discussion Paper 01093. Washington, DC, International Food Policy Research Institute.

21 S. Bhalotra, and M. Umaña-Aponte. 2009. Distress work amongst women? Micro data evidence from 66 developing countries on women's work participation as an insurance device. Bristol, UK, Department of Economics, University of Bristol.

22 J. Aranda, 2000. Respuestas campesinas a la crisis del café: las mujeres cafetaleras se organizan. In J. Aranda, C. Botey and R. Robles, eds. Tiempo de crisis, tiempo de mujeres. Oaxaca, Mexico, Universidad Autónoma Benito Juárez de Oaxaca.

23 M. Floro. 1995. Women's well-being, poverty and work intensity. Feminist Economics, 1(3): 1-25.

24 S. Baird and N.S. Friedman. 2007. Aggregate income shocks and infant mortality in the developing world. Policy Research Working Paper 4346. Washington, DC, The World Bank.

25 A. Chapoto and T.S. Jayne. 2010. Maize price instability in Eastern and Southern Africa: the impact of trade barriers and market interventions. Paper presented at the COMESA policy seminar on "Variation in staple food prices: causes, consequences and policy options", Maputo, Mozambique, 25-26 January 2010 (available at http://programmes. comesa.int/attachments/186_AAMP Maize price instability (7 Jan).pdf)

26 K. Basu. 1986. The market for land: an analysis of interim transactions. Journal of Development Economics, 20(1): 163-177.

27 For more information on the macroeconomic and political impacts, see: C.P. Timmer and D. Dawe. 2007. 
Managing food price instability in Asia: a macro food security perspective. Asian Economic Journal, 21(1): 1-18; A. Prakash. 2011. Why volatility matters. In A. Prakash, ed. Safeguarding food security in volatile global markets. Rome, FAO (available at http://www.fao.org/ economic/est/volatility/vgm/en/); and R. Arezki and M. Bruckner. 2011. Food prices and political instability. International Monetary Fund Working Paper 11/62. Washington, DC, International Monetary Fund.

28 S. Gillespie, A. Niehof and G. Rugalema 2010. AIDS in Africa: dynamics and diversity of impacts and response. In A. Niehof, G. Rugalema and S. Gillespie, eds. AIDS and rural livelihoods. London, Earthscan.

29 H. Kazianga and C. Udry. 2006. Consumption smoothing? Livestock insurance and drought in rural Burkina Faso. Journal of Development Economics, 79: 413-446.

30 M. Grimm. 2011. Does household income matter for children's schooling? Evidence for rural sub-Saharan Africa. Economics of Education Review, 30: 740-754; D. Cogneau and R. Jedwab. 2008. Household income and investments in child health and education in Ivory Coast. Paris School of Economics (mimeo)

31 J.E. Baez, and I.V. Santos. 2007. Children's vulnerability to weather shocks: A natural disaster as a natural experiment. New York, USA, Social Science Research Network (available at http://siteresources. worldbank.org/INTMIGDEV/ Resources/2838212-1237254959508/ Children_Vulnerability_to_Shocks Hurricane_Mitch_in_Nicaragua_as_a_ Natural_Experiment.pdf).

32 J. Hoddinott. 2006. Shocks and their consequences across and within households in rural Zimbabwe. Journal of Development Studies, 42(2): 301-321.

33 World Bank. 2006. Repositioning nutrition as central to development: a strategy for large-scale action. Washington, DC; J. Hoddinott, 2009. Early childhood nutrition increases adult wages.

EuroChoices, 8 (Special Issue): 34-37; J.A. Maluccio, J. Hoddinott, J.R. Behrman, R. Martorell, A.R. Quisumbing and A.D. Stein. 2009. The impact of improving nutrition during early childhood on education among Guatemalan adults. Economic Journal, 119(537): 734-763.

34 S. Maccini and Dean Yang. 2009. Under the weather: Health, schooling, and economic consequences of early-life rainfall. American Economic Review, 99(3): 1006-1026.

35 M.R. Carter, P.D. Little, T. Mogues, and W. Negatu. 2007. Poverty traps and natural disasters in Ethiopia and Honduras. World Development, 35(5): 835-856.

36 International Fund for Agricultural Development (IFAD). 2010. Rural Poverty Report. Rome.

37 M.R. Rosenzweig and K.I. Wolpin. 1993 Credit market constraints, consumption smoothing, and the accumulation of durable production assets in low-income countries: investments in bullocks in India. Journal of Political Economy, 101(2): 223- 244

38 T. Kurosaki and M. Fafchamps. 2002. Insurance market efficiency and crop choices in Pakistan. Journal of Development Economics, 67(2): 419-453.

39 S. Dercon and L. Christiaensen. 2011. Consumption risk, technology adoption and poverty traps: evidence from Ethiopia. Journal of Development Economics (in press)

40 OECD-FAO (2011) (see note 4).

41 Robles and Torero (2010) (see note 13).

42 N. Minot. 2011. Transmission of world food price changes to markets in subSaharan Africa. IFPRI Discussion Paper 01059. Washington, DC, International Food Policy Research Institute.

43 Demeke, Pangrazio and Maetz (2009) (see note 2)

44 See D. Dawe, ed. 2010. The rice crisis: markets, policies and food security. London, Earthscan and Rome, FAO, especially C. Fang, How China stabilized grain prices during the global price crisis; A Gulati and M. Dutta, Rice policies in India in the context of the global rice price spike; and A. Saifullah, Indonesia's rice policy and price stabilization programme: managing domestic prices during the 2008 crisis.

45 A. Shepherd. 2005. Review of the role of the private sector in meeting food emergencies in Zambia. Rome, FAO (available at http://www.fao.org/ fileadmin/templates/ags/docs/marketing/ esa/zambia.pdf).

46 See Chapoto and Jayne (2010) (note 25).

47 Cumulative inflation was about 20 percent in both the United States of
America and West African countries using the CFA franc during this period, so adjustment for inflation would not substantially affect the results.

48 Some Thai policies (e.g. domestic support prices) may indirectly affect the level of exports. Nevertheless, Thai domestic prices have tracked world prices nearly perfectly since 1986

49 G. Rapsomanikis and A. Sarris. 2008. Market integration and uncertainty: the impact of domestic and international commodity price variability on rural household income and welfare in Ghana and Peru. Journal of Development Studies, 44(9): 1354-1381.

50 P. Dorosh. 2009. Price stabilization, international trade and cereal stocks: world price shocks and policy response in South Asia. Food Security, 1: 137-149.

51 The sample includes all African countries for which data were available for either rice or wheat and one traditional staple. All available data from 2005 to 2010 were used in the analysis.

52 F.T. Portmann, S. Siebert and P. Döll. 2010. MIRCA2000 - Global monthly irrigated and rainfed crop areas around the year 2000: a new high-resolution data set for agricultural and hydrological modeling. Global Biogeochemical Cycles, 24, GB1011, $24 \mathrm{pp}$ doi:10.1029/2008GB003435

53 A. Quisumbing, R. Meinzen-Dick, L. Bassett, M. Usnick, L. Pandolfelli, C. Morden and H.Alderman. 2008. Helping women respond to the global food price crisis. IFPRI Policy Brief 7. Washington, DC, International Food Policy Research Institute.

54 D. Dawe. 2010. Cereal price transmission in several large Asian countries during the global food crisis. Asian Journal of Agriculture and Development, 6(1): 1-12; M. Hossain and U. Deb. 2010. Volatility in rice prices and policy responses in Bangladesh. In D. Dawe, ed. The rice crisis: markets, policies and food security. London, Earthscan and Rome, FAO.

55 I. Maltsoglou and Y. Khwaja. 2010. Bioenergy and food security: the BEFS analysis for Tanzania. Environment and Natural Resources Management Working Paper 35. Rome, FAO

56 H. Höffler and B.W. Owuor Ochieng 2009. High commodity prices - who gets the money? A case study on the impact 
of high food and factor prices on Kenyan farmers. Berlin, Heinrich-BoellFoundation (available at http://www. boell.de/downloads/worldwide/ HighFoodPrices-WhoGetsTheMoney Kenya.pdf).

57 B. Hill. 2008. Shaking the invisible hand. Rice Today, 7(4): 26-31.

58 P.F. Moya, D. Dawe, D. Pabale, M. Tiongco, N.V. Chien, S. Devarajan, A. Djatiharti, N.X. Lai, L. Niyomvit, H.X. Ping, G. Redondo and P. Wardana. 2004 The economics of intensively irrigated rice in Asia. In A. Dobermann, C. Witt and D. Dawe, eds. Increasing the productivity of intensive rice systems through sitespecific nutrient management, pp. 29-58. Enfield, NH, USA, Science Publishers, and Los Baños, Philippines, International Rice Research Institute.

59 S. Descargues. 2011. Impact of food price volatility on incomes and investment of smallholder farmers in Bangladesh. Rome, FAO.

60 Höffler and Owuor Ochieng (2009) (see note 56)

61 D. Headey, S. Malaiyandi, and S. Fan. 2010. Navigating the perfect storm: reflections on the food, energy and financial crises. Agricultural Economics, 41(s1): 217-228.
62 K.S. Imai, R. Gaiha and G. Thapa. 2011. Supply response to changes in agricultural commodity prices in Asian countries. Journal of Asian Economics, 22: 61-75.

63 J. Subervie. 2008. The variable response of agricultural supply to world price instability in developing countries. Journal of Agricultural Economics, 59(1): 72-92.

64 See Shepherd (2005) (note 45) and Chapoto and Jayne (2010) (note 25).

65 Often trade controls increase domestic prices above world prices - in such cases, these policies add to world supplies.

66 See Shepherd (2005) (note 45).

67 P. Villers and M. Gummert. 2009. Seal of approval: Hermetic storage of rice is becoming increasingly popular across Asia. Rice Today, 8(1): 36-37.

68 J.M. Harris, K. Erickson, J. Johnson, M. Morehart, R. Strickland, T. Covey, C. McGath, M. Ahearn, T. Parker, S. Vogel, R. Williams and R. Dubman. 2009. Agricultural income and finance outlook. Washington, DC. United States Department of Agriculture (available at http://usda.mannlib.cornell.edu/usda/ers/ AIS//2000s/2009/AIS-12-22-2009.pdf).

69 A.B. Banful. 2011. Old problems in the new solutions? Politically motivated allocation of program benefits and the "new" fertilizer subsidies. World Development, 39(7): 1166-1176.

70 B. Tortora and A. Rzepa. 2011. Recent trends in food security: a perspective from sub-Saharan Africans. Gallup Social and Economic Analysis.

71 E. Ligon and E. Sadoulet. 2007. Estimating the effects of aggregate agricultural growth on the distribution of expenditures. Background paper for the World Development Report 2008 (available at http://siteresources. worldbank.org/INTWDR2008/ Resources/2795087-1191427986785/ LigonE\&SadouletE EstimatingEffectsOfAggAgGr.pdf).

72 S. Daidone and G. Anríquez. 2011. An extended cross-country database for agricultural investment and capital. ESA Working Paper 11-16. Rome, FAO (available at http://www.fao.org/ docrep/014/am640e/am640e00.pdf).

73 FAO. 2009b. Investment. Issues Brief. High Level Expert Forum on How to Feed the World in 2050 (available at http:// www.fao.org/fileadmin/templates/wsfs/ docs/Issues_papers/HLEF2050_Investment. pdf).

74 S. Fan, 2008. Public expenditures, growth, and poverty: lessons from developing countries. Baltimore, MD, Johns Hopkins University Press. 


\section{NOTES for Annex table}

1. World Food Summit goal: halve, between 1990-92 and 2015, the number of undernourished people.

2. Millennium Development Goal 1, target 1C: halve, between 1990 and 2015, the proportion of people who suffer from hunger. Indicator 1.9 Proportion of population below minimum level of dietary energy consumption (undernourishment). The results are obtained following a harmonized methodology and are based on the latest globally available data averaged over three years. Some countries may have more recent data which, if used, could lead to different estimates of the prevalence of undernourishment and consequently of the progress achieved.

3. Latest report period refers to 2006-08 estimates and baseline refers to 1990-92. For countries that did not exist in the baseline period, the 1990-92 proportion of undernourished is based on 1993-95 and the number of undernourished is based on their 1990-92 population and his proportion.

4. The colour indicator shows the progress that is projected to be achieved by year 2015 , if current trend continues:

Target already met or expected to be met by 2015

Progress insufficient to reach the target if prevailing trends

persist

No progress, or deterioration

Country has a proportion of undernourishment below 5 percent

Countries revise their official statistics regularly for the past as well as the latest reported period. The same holds for population data of the United Nations. Whenever this happens, FAO revises its estimates of undernourishment accordingly. Therefore, users are advised to refer to changes in estimates over time only within the same The State of Food Insecurity in the World publication and refrain from comparing data published in editions for different years.

Country composition of the special groupings: least-developed countries, landlocked developing countries and small island developing states:

5. Includes: Afghanistan, Angola, Bangladesh, Benin, Burkina Faso, Burundi, Cambodia, Central African Republic, Chad, Comoros, Democratic Republic of the Congo, Djibouti, Eritrea, Ethiopia, Gambia, Guinea, Guinea Bissau, Haiti, Kiribati, Lao People's Democratic Republic, Lesotho, Liberia, Madagascar, Malawi, Mali, Mauritania, Mozambique, Myanmar, Nepal, Niger, Rwanda, Samoa, Sao Tome and Principe, Senegal, Sierra Leone, Solomon Islands, Somalia, Sudan, United Republic of Tanzania, Timor-Leste, Togo, Uganda, Vanuatu, Yemen and Zambia.
6. Includes: Afghanistan, Armenia, Azerbaijan, Bolivia (Plurinational State of), Botswana, Burkina Faso, Burundi, Central African Republic, Chad, Ethiopia, Kazakhstan, Kyrgyzstan, Lao People's Democratic Republic, Lesotho, Macedonia (The former Yugoslav Republic), Malawi, Mali, Republic of Moldova, Mongolia, Nepal, Niger, Paraguay, Rwanda, Swaziland, Tajikistan, Turkmenistan, Uganda, Uzbekistan, Zambia and Zimbabwe.

7 Includes: Antigua and Barbuda, Bahamas, Barbados, Belize, Cape Verde, Comoros, Cuba, Dominica, Dominican Republic, Fiji Islands, French Polynesia, Grenada, Guinea Bissau, Guyana, Haiti, Jamaica, Kiribati, Maldives, Mauritius, Netherlands Antilles, New Caledonia, Papua New Guinea, Saint Kitts and Nevis, Saint Lucia, Saint Vincent/Grenadines, Samoa, Sao Tome and Principe, Seychelles, Solomon Islands, Suriname, Timor-Leste, Trinidad and Tobago and Vanuatu.

Developing countries for which there were insufficient data are not included in the table.

8. In addition to the countries listed in the table, includes: Democratic Rep. of the Congo, Somalia, Cape Verde, Comoros, Djibouti, Guinea Bissau, Sao Tome and Principe, and Seychelles.

9. In addition to the countries listed in the table includes: Afghanistan and the Maldives.

10. In addition to the countries listed in the table, includes: Myanmar, Brunei Darussalam and Timor-Leste.

11. In addition to the countries listed in the table, includes: Iraq and Occupied Palestinian Territories.

12. In addition to the countries listed in the table, includes: Antigua and Barbuda, Bahamas, Barbados, Dominica, Grenada, Netherlands Antilles, Saint Kitts and Nevis, Saint Lucia and Saint Vincent/Grenadines.

13. In addition to the countries listed in the table includes Belize.

14. Includes: Fiji Islands, French Polynesia, Kiribati, New Caledonia, Papua New Guinea, Samoa, Solomon Islands and Vanuatu.

KEY

- Proportion less than 5 percent of undernourished

na Data not available

ns Not statistically significant

\section{SOURCES}

Total population: UN Population Prospects, 2008 revision. Undernourishment: FAO estimates. 
Cover photos: All photos are from the FAO Mediabase.

\section{Copies of FAO publications can be requested from:}

SALES AND MARKETING GROUP

Office of Knowledge Exchange, Research and Extension Food and Agriculture Organization of the United Nations Viale delle Terme di Caracalla 00153 Rome, Italy
E-mail: publications-sales@fao.org

Fax: (+39) 0657053360

Web site: http://www.fao.org/catalog/inter-e.htm 


\title{
The State of
}

\section{Food Insecurity in the World}

\author{
How does international price volatility affect \\ domestic economies and food security?
}

The State of Food Insecurity in the World 2011 highlights the differential impacts that the world food crisis of 2006-08 had on different countries, with the poorest being most affected. While some large countries were able to deal with the worst of the crisis, people in many small import-dependent countries experienced large price increases that, even when only temporary, can have permanent effects on their future earnings capacity and ability to escape poverty.

This year's report focuses on the costs of food price volatility, as well as the dangers and opportunities presented by high food prices. Climate change and an increased frequency of weather shocks, increased linkages between energy and agricultural markets due to growing demand for biofuels, and increased financialization of food and agricultural commodities all suggest that price volatility is here to stay. The report describes the effects of price volatility on food security and presents policy options to reduce volatility in a cost-effective manner and to manage it when it cannot be avoided. It will be important to provide improved market information, create gender-sensitive safety nets that are designed in advance and can be implemented quickly in times of crisis, and invest in agriculture for the long-term to make it more productive and resilient to shocks.

ISBN 978-92-5-106927-1

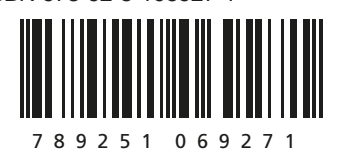

